\title{
PRÁTICA DA ELETRIFICAÇÃO RURAL EM SÃO PAULO
}

(1995-1997)

\author{
Dissertação apresentada à Escola \\ Politécnica da Universidade de São \\ Paulo para obtenção do título de Mestre \\ em Engenharia.
}


MARCELO APARECIDO PELEGRINI

\title{
PRÁTICA DA ELETRIFICAÇÃO RURAL EM SÃO PAULO
}

\author{
(1995-1997)
}

Dissertação apresentada à Escola

Politécnica da Universidade de São

Paulo para obtenção do título de Mestre em Engenharia.

Área de Concentração:

Sistemas de Potência

Orientador:

Fernando Selles Ribeiro

São Paulo

1998 
Pelegrini, Marcelo Aparecido

Prática da eletrificação rural em São Paulo (1995-1997). São Paulo, 1998.

$162 p$.

Dissertação (Mestrado) - Escola Politécnica da Universidade de São Paulo. Departamento de Engenharia de Energia e Automação Elétricas.

1. Eletrificação rural 2. Distribuição de energia elétrica - Aplicações I. Universidade de São Paulo. Escola Politécnica. Departamento de Engenharia de Energia e Automação Elétricas II. t 
Este trabalho é para meus pais, Osmar e Geralda, e para Andrea, que comigo constrói a vida. 


\section{AGRADECIMENTOS}

A meus irmãos, Mauricio, pela dedicação na revisão do trabalho e empréstimo de material, e Márcia pelo sorriso sempre presente.

Aos amigos e companheiros da Escola Politécnica, em especial ao Luiz e Anderson, pela dedicação à causa e ao estudo da eletrificação rural de baixo custo, e Miguel, pelas importantes correções.

A todos da CERESP, em especial Paulo de Tarso Carvalhaes, pelo exemplo, e Paulo de Tarso Liberalesso, pelas ponderações precisas e imensa paciência.

Ao Fábio e Ricardo, incansáveis batalhadores da eletrificação rural, pelas idéias e ensinamentos nas andanças por São Paulo.

À Karla e Eris pelo apoio logístico.

E, em especial, ao amigo e orientador Fernando Selles Ribeiro, pelo paciente e dedicado trabalho de apontar os rumos das pesquisas e da vida.

O agradecimento sincero do autor. 


\section{SUMÁRIO}

\section{RESUMO}

\section{ABSTRACT}

\section{CAPÍTULO 1 - A ELETRIFICAÇÃO RURAL É UM PROBLEMA DE DISTRI- BUIÇÃO DE ENERGIA ELÉTRICA? ............................................................................. 1}

1.1 UMA QUESTÃO SOCIAL, UMA QUESTÃO ECONÔMICA, UMA QUESTÃO TÉCNICA E,

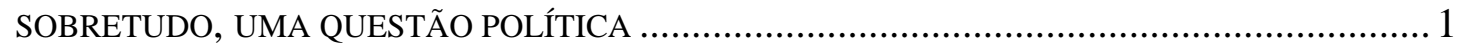

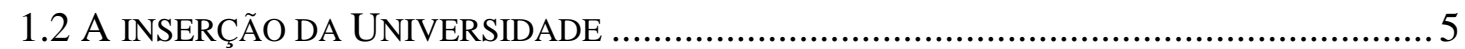

1.3 BNDES/USP: UMA PARCERIA COM PÚBLICO-ALVO DEFINIDO................................. 6

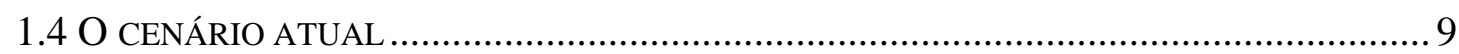

CAPÍTULO 2 - ELETRIFICAÇÃO RURAL, DESENVOLVIMENTO E POLÍTI-

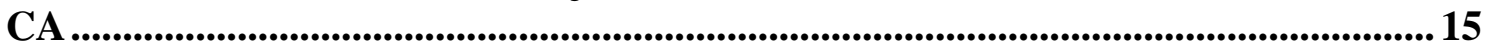

2.1 ASPECTOS GERAIS DA ELETRIFICAÇÃO RURAL …..................................................... 15

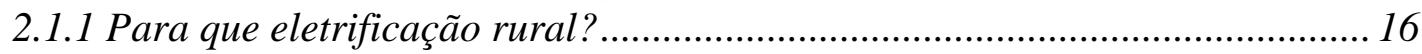

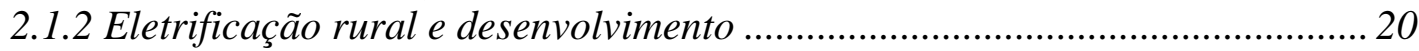

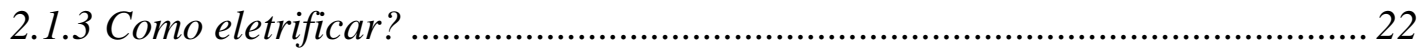

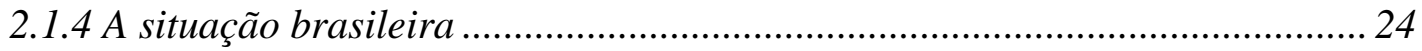

2.2 ASPECTOS POLÍTICOS DA ELETRIFICAÇÃO RURAL …….............................................26

2.2.1 A omissão do Estado, a omissão da concessionária ...................................... 29

2.2.2 Como, então, haver eletrificação rural? ........................................................ 33

CAPÍTULO 3 - ESTABELECENDO UMA POLÍTICA DE ELETRIFICAÇÃO

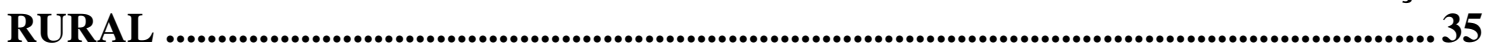

3.1 A UNIVERSIDADE IDENTIFICA UMA DEMANDA SOCIAL, MOSTRA SOLUÇÕES, IDENTIFICA UMA FONTE DE RECURSOS E APRESENTA AO GOVERNO UMA PROPOSTA DE

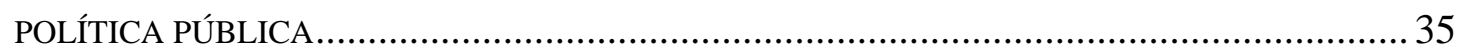

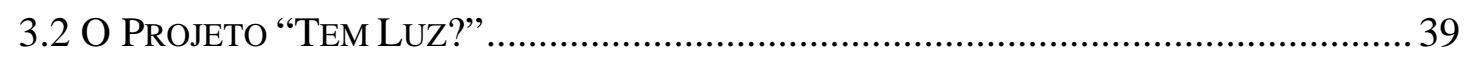

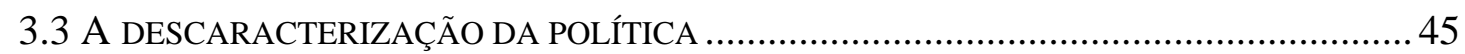

3.4 AS DIFICULDADES INSTITUCIONAIS APÓS O LANÇAMENTO ...................................... 50

CAPÍTULO 4 - O PROGRAMA "LUZ DA TERRA" VAI A CAMPO ...................64

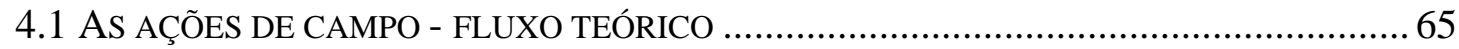

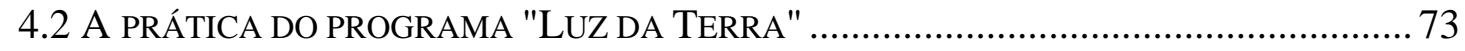



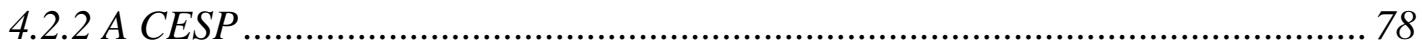

4.2.3 A Companhia Paulista de Força e Luz........................................................... 87



4.2.5 A Nossa Caixa Nosso Banco ......................................................................... 97

4.2.6 As Concessionárias Privadas e as Cooperativas de Eletrificação Rural ..... 101

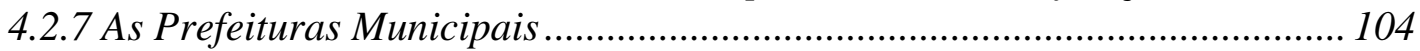

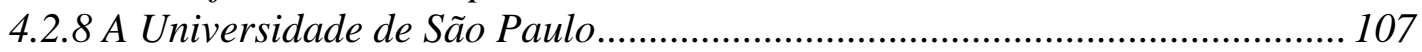

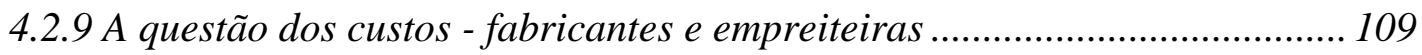

4.2.10 A Secretaria de Energia ............................................................................. 113 


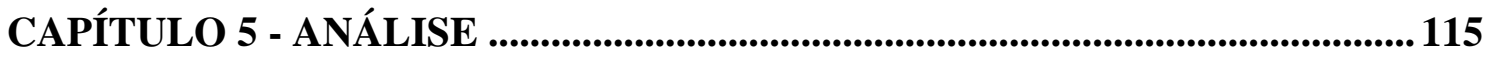

5.1 O MODELO, O FLUXOGRAMA E A AÇÃO POLÍTICA................................................... 115

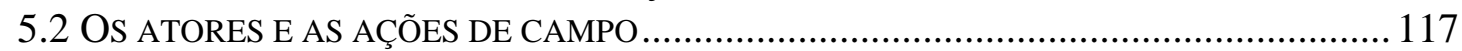

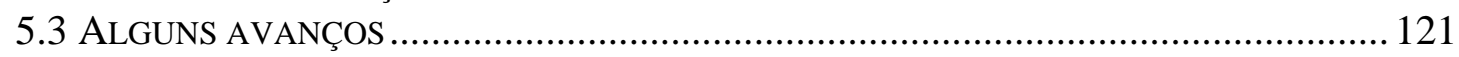

CAPÍTULO 6 - RESGATANDO A PROPOSTA INICIAL: SUGESTÕES PARA UMA EFETIVA IMPLEMENTAÇÃO DA POLÍTICA PLANEJADA................ 123

6.1 A COMUNIDADE NO MODELO BNDES/USP ........................................................ 123

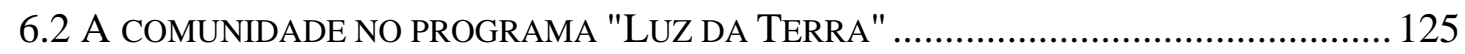

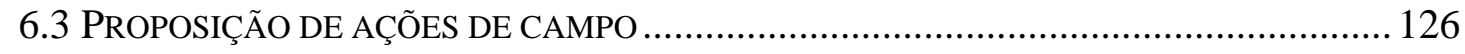

6.3.1 Zé da Luz e o Serviço Municipal de Eletrificação Rural ............................... 127

6.3.2 A questão da divulgação de informações........................................................ 132



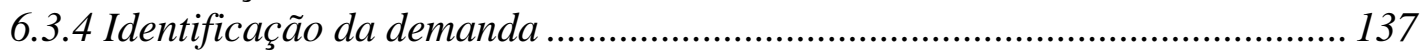

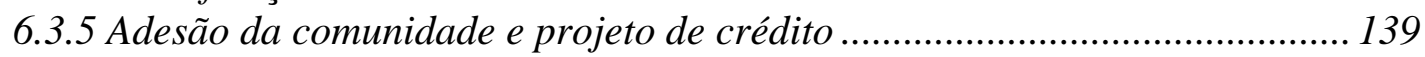

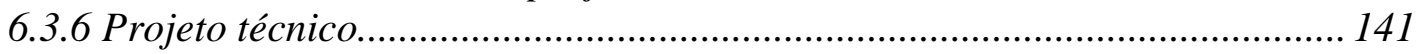

6.3.7 Contratação do financiamento e execução das obras.................................... 143



CAPÍTULO 7 - CONSIDERAÇÕES FINAIS .......................................................... 147

7.1 O QUE MAIS FAZER PARA AMPLIAR O ALCANCE DA POLÍTICA? .............................. 147

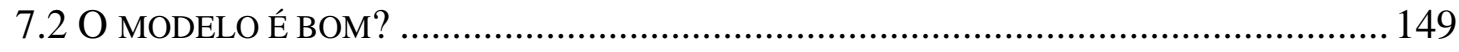

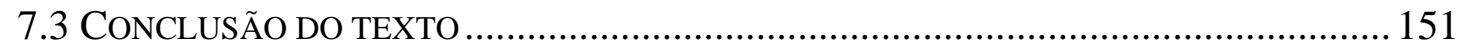

REFERÊNCIAS BIBLIOGRÁFICAS .................................................................... 155

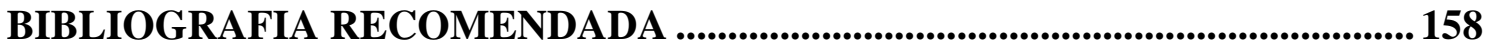




\section{RESUMO}

O fornecimento de energia elétrica é uma função social do Estado outorgada às concessionárias. Preocupadas em manter padrões de qualidade e reduzir custos para atingir seu objetivo maior que é o lucro, as empresas de energia não se interessam pela extensão de seu serviço para atender populações rurais pobres.

O governo do estado de São Paulo planejou uma política de eletrificação rural com o objetivo de promover a valorização social da vida no campo. Baseado em um modelo desenvolvido pelo Banco Nacional de Desenvolvimento Econômico e Social em parceria com a Universidade de São Paulo, foi proposto o programa "Luz da Terra", envolvendo vários novos atores e deixando para as concessionárias o papel de executar serviços de engenharia somente.

Este trabalho analisa o processo de planejamento, o arranjo institucional e a prática de implantação desse programa em sua primeira fase. Os fracos resultados são atribuídos à falhas no arranjo institucional e nas ações de campo. O eixo do programa deslocou-se das comunidades e do poder local para as concessionárias. Em sua prática, o programa negou o modelo. Nesse contexto, são sugeridas medidas corretivas. 


\begin{abstract}
The electric energy supply is a State social matter granted to the utilities. Worried in to maintain quality patterns and to reduce costs to reach its larger objective that it is the profit, the utilities are not interested in the extension of its service to assist poor rural populations.

The state of São Paulo government has planned a rural electrification politics aimed to promoving the social valuation of the life in rural areas. Based on a model developed by the Banco Nacional de Desenvolvimento Econômico e Social in partnership with the Universidade de São Paulo, the program "Luz da Terra" was proposed it, involving several new actors and passing to the utilities the task of executing engineering services only.
\end{abstract}

This work analyses the planning process, the institutional arrangement and the practice of that program in its first phase. The weak results are attributed to mistakes in the institutional arrangement and in the country actions. The program axis moved from the communities and the local power to the utilities. In its practice, the program denied the model. In that context, this work suggests actions to correct it. 


\section{CAPÍTULO 1 - A ELETRIFICAÇÃO RURAL É UM PROBLEMA DE DISTRIBUIÇÃO DE ENERGIA ELÉTRICA?}

\subsection{Uma questão social, uma questão econômica, uma questão técnica e, sobretudo, uma questão política}

O desenvolvimento de políticas sociais é uma atribuição do Estado, como meio de atender o direito de cada cidadão de ter acesso aos serviços públicos. Ao conduzir esse processo, o Estado tenta fazer crer que atua na concepção e na implementação de propostas que têm como objetivo o desenvolvimento conjunto da nação e que os critérios de decisão resultam de avaliações objetivas de como atingir as metas propostas (TENDRIH, 1990).

As políticas sociais explicitam-se através da atuação concreta de organismos e agências estatais encarregados de implementá-las.

O fornecimento de energia elétrica é uma função social do Estado outorgada às concessionárias.

É uma matéria que diz respeito a uma estratégia de desenvolvimento do modelo econômico. O eixo do modelo desenvolvimentista brasileiro é sempre voltado para o crescimento e a modernização da produção de bens que tenham retorno econômico. A eletrificação rural não induz crescimento, nem retorno econômico nem alguma outra taxa que possa colocá-la na pauta do desenvolvimento.

Não há onde discutir eletrificação rural no âmbito federal. É uma omissão de longa data. Nos anos entre 1980 e 1990 o Brasil atendeu a menos de 2 \% das necessidades de sua área rural, entrando em 1990 com 73 \% das propriedades no escuro. 
O estado de São Paulo tem no seu território reservatórios que são capazes de gerar energia renovável capas de acender três Chiles, vinte e cinco Bolívias, mas tem também 1.200.000 pessoas vivendo no escuro em metade de suas propriedades rurais, segundo a Eletrobrás.

Ausente o Estado, as coisas se passam como se a responsabilidade social, que é sua, fosse assumida pela empresa de energia juntamente com outorga de poderes. $\mathrm{Na}$ prática, essa transferência não se realiza.

Todavia, no setor elétrico e na Agricultura, as áreas que mais se aproximam do assunto, bem como em quase todos os setores dos governos federal e estaduais, é consensual que o tema pertença à concessionária.

A eletrificação rural, pela sua natureza, é um problema de distribuição de energia elétrica. É comum o entendimento que não seja mais do que a extensão das atividades normais da empresa para mercados distantes, dispersos e nada lucrativos e que não requeira qualquer consideração institucional especial. Não motiva engenheiros, técnicos e agentes, muito pelo contrário. Em algumas empresas a eletrificação rural fica na área de engenharia de distribuição, em outras na área de comercialização, em quase todas elas é depositária do pessoal menos prestigiado dessas áreas, salvo quando surgem verbas externas para gastar.

A concessionária tem obrigações muito bem definidas com relação a seus clientes. Vive sob a pressão da busca constante ao lucro e aos índices de qualidade satisfatórios. O cliente que reclama, que consome, que dá lucro é o urbano.

A população rural que permanece sem luz é pobre, não vai consumir, vai dar prejuízo e não reclama. Não tem voz e não tem representatividade. Nunca vai se 
constituir em prioridade para a concessionária. Vai permanecer no escuro e no esquecimento.

A concessionária é posta perante um dilema (FOLEY, 1992).

Por um lado, não pode dizer que vai deixar de atender mercados dentro de sua área de concessão. Por outro lado, não vai conseguir conciliar o atendimento de populações rurais pobres com os objetivos da empresa.

A maneira que ela encontra para sair do dilema é negar a existência do problema.

Nega, primeiramente, a existência da demanda não atingida. Uma das concessionárias públicas de São Paulo se manifestou assim:

"em nossa área não há necessidade de programa de eletrificação rural porque o mercado considerado viável já está quase todo atendido. Resta um resíduo de mercado que não é considerado viável, e por isso, não interessa (abril de 1995)”.

Ou, como afirmou outro responsável pelo tema dentro de outra concessionária pública:

"nós não temos necessidade de fazer eletrificação rural. Todos estão atendidos. Há bolsões de pobreza, mas são tão pobres que não interessam à empresa" (agosto de 1990) (RIBEIRO, 1993, p. 52).

Ou ainda como dizia a terceira concessionária pública de São Paulo, a primeira a ser privatizada:

“Não há pessoas de baixa renda sem luz em nossa área” (abril de 1996).

De fato, o agente que diz que não atende porque pobre não deve ter luz - pobre rural, porque o urbano tem luz, reforçando pressões migratórias para as periferias social e urbana das cidades grandes - ou, no terceiro mundo, nega ver pobre no interior, está 
discriminando em nome do Estado. Sua empresa discrimina em nome do Estado. O Estado discrimina em nome de uma distribuição da riqueza nacional perversa que se faz acompanhar por uma também perversa distribuição de energia nacional.

O Banco Nacional do Desenvolvimento Econômico e Social - BNDES e a Escola Politécnica da Universidade de São Paulo se associaram para entender os motivos que impedem que pequenos produtores rurais tenham acesso aos serviços públicos de energia elétrica.

As mais importantes agências internacionais de financiamento e fomento de projetos de infra-estrutura nos países em desenvolvimento, tais como o "World Bank", o “Asian Development Bank”, a “USAID”, a “Comission of the European Communities”, entre outras, ao analisar os resultados de políticas extensivas de eletrificação rural em países em desenvolvimento manifestam opiniões convergentes. Em primeiro lugar, entendem que eletrificação rural é uma questão social que deve ser resolvida por uma agência de desenvolvimento, de preferência nacional, externa e independente à concessionária, cujos objetivos não se coadunam com o atendimento de populações rurais pobres. Em segundo lugar, as agências internacionais afirmam que os relatos de sucesso em tais políticas estão sempre associados a uma atividade comunitária de parceria com os executores dos programas, com forte envolvimento das lideranças comunitárias nos processos.

Levando em consideração esses dois pontos importantes, que, de fato, são consistentes com a experiência do BNDES em programas de eletrificação rural para produtores de baixa renda, esse banco e a Escola Politécnica desenvolveram um modelo de eletrificação rural. 
O BNDES apresentou ao governo de São Paulo a proposta de um projeto estadual de eletrificação rural explicitamente voltado para o atendimento da população pobre. Esse projeto foi consolidado no programa "Luz da Terra".

Este trabalho faz a análise sistêmica da prática de implantação dessa política e propõe correções a essa prática.

\subsection{A inserção da Universidade}

A Universidade pode interferir no processo da eletrificação rural de três maneiras, que aliás, são os seus três motivos de existir.

Em primeiro lugar, preparando mão-de-obra especializada que tenha consciência das responsabilidades sociais que acompanham as ações dos técnicos - principalmente os engenheiros eletricistas - na definição e perseguição dos alvos da distribuição de energia.

Em segundo lugar, há muita pesquisa por ser feita no sentido de desenvolver tecnologia capaz de conseguir o fornecimento de energia a todos os cidadãos, de forma segura, confiável, de boa qualidade e, sobretudo, barata. Esta dissertação trata de uma das formas possíveis de se alcançar essa meta, que é a conexão ao sistema elétrico de potência convencional. Contudo, centros de pesquisa no mundo todo estão estudando a viabilização técnica e econômica de fontes alternativas de energia, principalmente a eólica e a fotovoltaica, atualmente ainda muito caras. O Brasil é um mercado cobiçadíssimo pelos fabricantes de painéis solares, pelas suas características naturais e pela grande parcela da população rural ainda não atendida pelas redes de distribuição. 
Finalmente, a Universidade é uma instituição que tem como uma de suas obrigações disseminar os conhecimentos que gera ou adquire. Deve estar atenta às necessidades reclamadas pela sociedade. E, função nobre que a acompanha desde a criação das primeiras Universidades, ela tem a natureza de ser um ente perturbador do marasmo social, denunciador de iniqüidades e propositor de soluções viáveis. A Universidade, muitas vezes, tem a oportunidade de ver e sentir a vida e seus atores de uma posição privilegiada de espectadora, que se isenta para observar e fazer juízo de valor.

A Universidade faz o seu juízo de valor e se manifesta com a liberdade que a isenção lhe permite. Assim se espera. Assim tem acontecido a ação da Escola Politécnica da Universidade de São Paulo, em conjunto com outras instituições, provocando importantes mudanças na cultura técnica em um setor extremamente conservador e pouco inclinado a escutar opiniões externas.

\subsection{BNDES/USP: uma parceria com público-alvo definido}

A eletrificação rural chegou à Universidade de São Paulo por demanda do BNDES.

Conforme conta o professor Fernando Selles Ribeiro, em meados de 1987 técnicos da Diretoria de Desenvolvimento Rural do BNDES solicitaram a professores da Escola Politécnica informações sobre eletrificação rural simplificada. Trata-se de um centro bastante envolvido com a engenharia de distribuição de energia elétrica, o que é raro, tanto no Brasil, como em muitos outros países. Havia, naquela época, um convênio entre a Universidade e a Eletrobrás, pelo qual era aberto a engenheiros funcionários de todas as concessionárias do Brasil, desde que militantes dos setores de distribuição de 
energia, o acesso a um curso de mestrado especializado nesse ramo, intitulado Curso Avançado em Distribuição Elétrica (CADE).

Era de se esperar que esse ambiente acadêmico fosse receptivo à idéia de se estudar o problema da distribuição rural e que fosse rico em conhecimentos nessa área.

Todavia, o tema proposto era praticamente desconhecido. Os professores do então Departamento de Engenharia de Eletricidade declararam desconhecer a aplicação do Sistema Monofilar com Retorno por Terra - Sistema MRT - nas redes rurais. Seus alunos, os engenheiros especialistas que cursavam o CADE, se conheciam o MRT, recomendavam fortemente que dele não se devia fazer uso. A própria eletrificação rural era tida como de interesse secundário. Inovações tecnológicas passavam a ser incorporadas nas redes de distribuição, quebrando uma rotina de trabalho de algumas décadas e criando necessidades de estudos em outras áreas. A distribuição - urbana passava a se preocupar com questões como qualidade da energia, harmônicos, compatibilidade magnética, comando remoto, proteção digital, etc., com certeza temas desconhecidos da maioria dos engenheiros da área, então.

Com tantos assuntos para se preocupar, quem haveria de se interessar por sistemas monofilares com condutor de ferro e poste de madeira, cercados ainda de forte fama de insegurança, maus serviços e dificuldades de manutenção?

Coube ao BNDES levar a eletrificação rural à Escola Politécnica. Porém, mérito maior lhe cabe pela maneira como os professores e pesquisadores foram chamados a discutir o problema: pelo lado da demanda social!

A Escola Politécnica da Universidade de São Paulo entendeu que lhe competia investigar cuidadosamente os impactos sociais, econômicos e ambientais da 
eletrificação rural, juntamente com os aspectos técnicos específicos da proposta de redes de distribuição simplificadas. Ribeiro declara que

"dentro da Escola Politécnica, o estudo deste problema provocou uma ruptura de preconceitos com relação ao emprego de tecnologias simplificadas e com relação à função social da energia. Em conseqüência, deu-se uma mudança de atitude de professores e da própria Escola face às responsabilidades sociais da engenharia de distribuição de energia elétrica” (RIBEIRO, 1995, p. 3).

Atendendo a uma solicitação do BNDES, a Universidade de São Paulo propôs à Secretaria da Ciência, Tecnologia e Desenvolvimento Econômico do Estado de São Paulo (SCDTE) um projeto de pesquisa multidisciplinar com o título de "Eletrificação Rural de Baixo Custo”. Formou-se um grupo de pesquisa que teve a participação de trinta pessoas, em 1989. Foi possível a esse grupo acadêmico deslocar equipes para vários estados (Rio Grande do Sul, Paraná, Rio de Janeiro, Espírito Santo, Minas Gerais e Bahia), para estudos referentes ao modelo proposto pelo BNDES.

Montou-se um quadro da eletrificação rural no Brasil. RIBEIRO (1993) demonstra que os resultados desse trabalho se traduziram em ações da Escola Politécnica nos âmbitos do ensino, da pesquisa e da prestação de serviços à comunidade:

1) o ensino de engenharia elétrica passou a transmitir informações sobre tecnologias e materiais que possibilitam alcançar custos baixos na eletrificação rural;

2) foi instituída uma linha de pesquisa intitulada “Eletrificação Rural de Baixo Custo”, nos programas de pós-graduação nos níveis de mestrado e doutorado;

3) a Politécnica se posicionou como interlocutora do BNDES na discussão do problema. Fruto desse posicionamento foi a participação conjunta das duas instituições em discussões com governos estaduais de diferentes estados, tais como 
Rio Grande do Sul, Espírito Santo, São Paulo e Bahia sobre a possibilidade de implantação de políticas regionais de eletrificação rural.

A ação conjunta BNDES/USP partiu do pressuposto de que era necessário identificar os motivos que impediram a eficácia dos programas de expansão da distribuição rural instituída pelas concessionárias de energia. TENDRIH (1990) faz um apanhado histórico desses programas no Brasil. SANTOS; RIBEIRO (1995) ressaltam que, considerados tão ou mais importantes que as próprias questões de engenharia, a análise das peculiaridades sócio-econômicas da atividade do homem do campo e o estudo das suas relações costumeiras com o Estado e os bancos serviram de base para a proposição de uma nova maneira de enfocar o problema, com o requisito fundamental de garantir o atendimento do público-alvo mais difícil de se atingir: o pequeno produtor rural.

\subsection{0 cenário atual}

A eletrificação rural não é um tema isolado. As políticas de eletrificação são fortemente influenciadas pelo que acontece em vários outros campos, econômicos e sociais. Novos cenários, movidos pela conjuntura mundial, motivam os programas a buscar novos caminhos.

Grande parte do mercado rural considerado viável pelas empresas distribuidoras de energia elétrica e fabricantes de equipamentos, formado por grandes consumidores rurais que utilizam a energia elétrica para fins produtivos, encontra-se ligada à rede existente. A grande demanda a ser atendida, hoje, é formada pelos menores e mais pobres habitantes da área rural, freqüentemente considerados como deficitários pelas 
companhias elétricas. Exatamente este público não era considerado “mercado viável”, formando um “resíduo” que "não se interessava por energia”.

A liberalização cada vez maior no campo econômico leva à abertura de mercados, à globalização dos processos produtivos e à dinamização dos mercados financeiros. O Estado é compelido a se afastar do setor de infra-estrutura. Companhias energéticas são privatizadas, e a competição e a busca por competitividade aumentam fortemente. A energia, cada vez mais, é vista somente como um negócio. A empresa de energia, no mundo todo, está se tornando meramente uma empresa que, como tal, visa lucro para seus acionistas privados através do negócio da energia.

Nisso, uma marotagem é raciocinar afirmando que a função da empresa é apenas ter lucro e que, portanto, não é função da empresa de energia privatizada fazer eletrificação rural porque ela representa prejuízo. Paira um grande preconceito dentro das concessionárias com relação ao trabalho que se aplica a mercados não rentáveis.

Na privatização das concessionárias brasileiras houve hesitação na abordagem desse tema. Há casos em que o próprio governo já percebeu que os cuidados que tomou com o processo de privatização não foram suficientes para garantir o atendimento rural que se imaginava assegurado.

Na privatização das três empresas estatais de distribuição paulistas, depois da primeira delas ser vendida o governo do estado providencia instrumentos que vão obrigar os futuros interessados na CESP e na Eletropaulo a realizar certo número de ligações rurais por ano, durante quatro anos. Já com relação à venda da CPFL não se tomou o mesmo cuidado. No entanto, os compradores têm dado mostras de que se 
interessam em dar apoio à política de eletrificação rural planejada pelo governo e analisada nesse trabalho.

Nos governos, a escassez de recursos para investimento e a busca incessante do equilíbrio fiscal provoca redução da participação financeira nos programas de eletrificação rural. Não há mais dinheiro para fornecer redes e sistemas elétricos praticamente de graça aos moradores rurais, como no passado.

No campo tecnológico, a falta de recursos deveria provocar, e em certos casos provoca, o estudo e o advento de alternativas que possam reduzir os custos da eletrificação rural. Nessa área, uma outra marotagem, presente na literatura e nas discussões sobre o tema, é dizer que o modelo tradicional de distribuição rural faliu dado que as concessionárias não mais se interessam por fazer as ligações necessárias - e portanto não se deve insistir com as políticas de extensão da rede elétrica. A solução estaria nas novas tecnologias fotovoltaicas e eólicas. E segue um discurso de que o sistema fotovoltaico é muito mais barato e usa energia renovável e gratuita, que não se deve aumentar a poluição global etc., etc., etc.

Aliás, nesse discurso que, muitas vezes, é de lobista do vendedor de painel, é costume esquecerem que o próprio sistema elétrico central do Brasil é movido por energia renovável, diferentemente dos sistemas dos países industrializados.

A energia fotovoltaica é importantíssima para solução da falta da luz elétrica em lugares onde vai demorar muito tempo para chegar a rede nas proximidades. Existem muitos lugares assim no território brasileiro, principalmente na região amazônica e nas pontas dos dois sistemas elétricos interligados, por exemplo, na Bahia. Há instalações 
fotovoltaicas de bombeamento de água para pequenas cidades em experiência. Há experiências de bombeamento a partir da energia eólica.

Há uma grande página da ciência e da tecnologia que está sendo virada. Aplicações de aproveitamento de energia solar são determinantes na viabilização de algumas empreitadas, como na engenharia espacial e em telecomunicações. Existem grandes coletores solares em fase de testes, gerando consideráveis blocos de energia para ser agregada ao sistema elétrico central. Tais aplicações são caras, embora algumas delas sejam economicamente viáveis.

Agora, dizer que para o pobre rural tanto faz estar conectado à rede ou a um sistema fotovoltaico - que, tipicamente, permite o uso de oito horas diárias, às vezes menos, de lâmpada e uma tomada que não serve para aparelho de força ou aquecimento - pelo mesmo preço é exagero. Permitir que se falseiem dados de custos, exagerando o valor a ser pago pela conexão à rede, só para “viabilizar” a opção concorrente, é exagero de vendedor mal intencionado ou de governos ávidos para empurrar uma tecnologia em que eles são predominantes.

A marotagem desse discurso acaba servindo para atrasar a solução daquelas situações onde tais tecnologias são adequadas e recomendáveis. Na ganância pela conquista do mercado fica um rastro de desconfiança que afasta algumas agências sérias, sendo que a demanda que efetivamente há no Brasil, nas condições cuja indicação para suprimento fotovoltaico é correta, é das maiores do mundo.

Por outro lado, o tema “eletrificação rural”, quando referido a projetos de extensão de rede, tem sido pouco explorado nos últimos cinco anos. 
Na área política, o avanço da democracia em vários países tem estimulado, mesmo de forma lenta, as pessoas a participar dos processos decisórios. A Agenda 21, em seu capítulo 14, realça esse aspecto e recomenda

"fortalecer e desenvolver o manejo e as capacidades internas das organizações das populações rurais e dos serviços de extensão e descentralizar a tomada de decisões para o nível básico da comunidade" (CONFERÊNCIA DAS NAÇÕES UNIDAS SOBRE MEIO AMBIENTE E DESENVOLVIMENTO, 1992, p. 180).

Os poderes locais, as comunidades e a sociedade têm sido vistos cada vez mais como interlocutores privilegiados de formulação e implantação de políticas públicas de energia.

Todas essas mudanças pedem uma redefinição das políticas de eletrificação rural. O modelo proposto pelo BNDES e pela Universidade de São Paulo contempla isso: se antes a eletrificação rural era vista principalmente como estímulo ao desenvolvimento econômico e acessível a alguns poucos privilegiados, hoje o objetivo principal deve ser a luz elétrica e o conforto no lar, estendidos a todos os moradores rurais. Novas formas de financiamento são adotadas, com esquemas que permitam o pagamento pelo produtor pobre, utilizando inclusive mecanismos de equivalência em produto. Outras entidades além das empresas de energia elétrica se envolvem no processo, como agências de desenvolvimento e órgãos de extensão rural. A sociedade como um todo tem que estar envolvida no atendimento dessa demanda, articulando os poderes locais.

A política deve ser voltada para a não exclusão social e o programa ter como objetivo explícito incluir o pobre rural no seu público-alvo. É preciso identificar agentes dentro das instituições envolvidas que concordem com o objetivo de não excluir os mais pobres, tarefa em que a Universidade pode ter grande atuação. 
Um programa de eletrificação rural contemporâneo deve contemplar esse novo cenário. Estratégias que possibilitem a implantação desse novo modelo têm que ser propostas e estudadas na prática. As comunidades rurais devem ter atuação ativa e organizada em todas as etapas do processo, desde a identificação da demanda até a construção das redes de energia elétrica. A adequação do suprimento energético às reais necessidades do homem do campo deve redirecionar os projetos para o uso de sistemas simplificados de extensão de rede e a utilização de fontes renováveis de energia elétrica.

Face a isso, um programa de eletrificação rural derivado de um modelo que contempla essas preocupações, e que realiza apenas 1.200 das 30.000 ligações planejadas para o seu primeiro ano, necessita ter sua prática estudada, para a verificação das razões desse aparente fracasso. 


\section{CAPÍTULO 2 - ELETRIFICAÇÃO RURAL, DESENVOLVIMENTO E POLÍTICA}

Neste capítulo se pretende fazer uma análise do tema Eletrificação Rural de Baixo Custo, sob a perspectiva política. Para tanto, está dividido em duas partes: na primeira, o tema é apresentado e suas implicações sociais e econômicas são brevemente discutidas. A segunda parte enfoca principalmente as barreiras existentes à implantação de políticas de eletrificação rural.

\subsection{Aspectos gerais da eletrificação rural}

A primeira questão que surge quando da análise do tema eletrificação rural é a diferenciação que existe entre energização rural e eletrificação rural.

A energização rural envolve o estudo de todas as formas e inter-relações pelas quais a energia, em suas diversas fontes e modalidades, pode ser utilizada no meio rural.

A eletrificação rural, então, pode ser entendida como uma subdivisão nos estudos de energização rural, compreendendo especificamente a utilização e o ato de propiciar o acesso à energia elétrica nesse meio. E propiciar o acesso não só às propriedades que exerçam atividades produtivas, como freqüentemente o tema é visto pelas agências responsáveis, incluindo concessionárias, governos e agências de desenvolvimento, mas sim, à totalidade dos cidadãos da zona rural.

Mas por que, dentro de estudos de energização rural, enfocar o uso da energia elétrica? Porque a energia elétrica é, hoje, parte indispensável da cultura e dos recursos da sociedade moderna. A maioria dos modernos meios de comunicação, eletrodomésticos, fontes de iluminação, equipamentos para otimização e incremento da 
produção são movidos à eletricidade, de tal modo que é inconcebível imaginar a vida contemporânea sem os confortos advindos de todas as formas de utilização dessa forma de energia. Isto sem contar com o progresso representado pelo advento do motor elétrico, que pode executar tarefas pesadas com elevadíssimo rendimento energético, a um baixo custo.

\subsubsection{Para que eletrificação rural?}

A eletrificação rural é vista, na maioria das vezes, como uma forma de incrementar atividades produtivas, através da utilização de equipamentos agrícolas que possuem eficiência energética maior que a dos equipamentos tradicionalmente usados em tarefas como secagem e moagem de grãos, bombeamento de água, trituração de milho e outros produtos para elaboração de ração para gado e aves (permitindo a criação intensiva em regime de confinamento, que melhora substancialmente os resultados pecuários), refrigeração, etc. Estas utilizam, ainda em muitos lugares, fontes energéticas derivadas do petróleo, como óleo diesel e gasolina, que custam mais caro e são de difícil obtenção, principalmente por causa das dificuldades de transporte. Em outras regiões, geralmente menos desenvolvidas economicamente, o uso de lenha e esterco, principalmente para aquecimento, é bastante comum. O uso de energia elétrica, desse modo, traz vantagens como economia de recursos financeiros, conservação de recursos naturais e diminuição da poluição e da dependência global de petróleo, em alguns países.

A eletrificação possibilita o surgimento de uma agricultura mais moderna através do emprego de irrigação e melhores técnicas de processamento e armazenamento de alimentos. Estudos realizados no estado de São Paulo mostram que, 
só com a irrigação, foi possível o imediato aumento da produção, da ordem de 70 \% em culturas como a soja, porcentagem que, no caso do milho, chegou a $120 \%$. Num experimento piloto do BNDES, no Projeto Santa Luzia, no Ceará, a substituição do cultivo do arroz de sequeiro por arroz irrigado aumentou a produção total de dois anos de $9.600 \mathrm{~kg}$ para $80.000 \mathrm{~kg}$ depois de implantado um projeto piloto de irrigação (TEIXEIRA, 1988). Mesmo que já exista, na propriedade rural, irrigação movida a derivados de petróleo, a energia elétrica traz uma economia significativa de recursos.

A inserção do homem do campo no universo dos consumidores de energia elétrica pode também permitir a abertura de um grande mercado para eletrodomésticos. Estudos realizados dentro do projeto PROLUZ, no Rio Grande do Sul, demonstram que o pequeno produtor busca primeiro adquirir aparelhos que permitam aumentar a renda familiar (o freezer, para congelar água e possibilitar uma segunda ordenha, já que o transporte de leite é matinal e não havia como conservá-lo durante a noite), que proporcionem maior conforto em sua casa e que propiciem possibilidades de entretenimento para sua família, conforme mostra a Tabela 1 (RIBEIRO; SANTOS, 1994, p. 144): 
Tabela 1

Aparelhos Adquiridos no Âmbito da Amostra PROLUZ - 1

\begin{tabular}{ccc}
\hline TIPOS DE APARELHOS & $\begin{array}{c}\text { NÚMERO DE APARELHOS } \\
\text { ADQUIRIDOS }\end{array}$ & \% DA AMOSTRA \\
\hline Refrigerador & 613 & 52.6 \\
\hline Freezer & 440 & 37.8 \\
\hline Televisor & 439 & 37.8 \\
\hline Chuveiro Elétrico & 492 & 42.2 \\
\hline Rádio & 338 & 29.0 \\
\hline Ventilador & 150 & 12.9 \\
\hline Bomba d'água & 339 & 29.1 \\
\hline Quebrador de Milho & 51 & 4.4 \\
\hline Picador & 24 & 2.0 \\
\hline Outros & 483 & - \\
\hline Total & 3369 & - \\
\hline
\end{tabular}

Fonte: Banrisul (1994).

Obs.: amostra $=1.165 ;$ produtores atendidos $=4.048$; amostra de $28,8 \%$.

Nos Estados Unidos, quando da implantação de um extenso programa de eletrificação rural na década de 30, os fabricantes de eletrodomésticos e equipamentos, percebendo a potencialidade dessa demanda reprimida, mostravam grande interesse em participar do programa com demonstrações de seus produtos, buscando aumentar o mercado para eles.

Obviamente, a aquisição destes equipamentos produz um aumento da arrecadação de impostos nas diversas esferas do poder público, fato que tradicionalmente não é levado em conta quando da análise de retorno e viabilidade econômica destes projetos. Estimativas conduzidas pela CEMIG, demandadas pelo Banco Mundial, mostraram que no período de 1984/89, o valor arrecadado de impostos 
atingiu US\$ 3.000/propriedade com a aquisição de equipamentos elétricos em 5.380 propriedades eletrificadas (RIBEIRO; SANTOS, 1994).

Um aspecto muito forte da eletrificação rural é a possibilidade de melhorar a qualidade de vida da zona rural. A falta de eletricidade favorece a estagnação do homem do campo, colocando-o à margem das inovações tecnológicas e das modernas formas de comunicação. A importância que a televisão tem em alguns países desprovidos de alternativas culturais ultrapassa os aspectos de entretenimento e lazer, tornando-se um meio de integração política e cultural. Sem energia elétrica, o homem do campo sofre um certo “isolamento eletrônico” tornando-o um cidadão que pouca possibilidade tem de participar das decisões que afetam a sua vida, até pela falta de conhecimento delas.

A posse de luz elétrica para iluminar sua casa é motivo de orgulho para o camponês, que se vê de forma definitiva integrado ao mundo moderno. A iluminação doméstica permite-lhe adequar a jornada de trabalho conforme lhe convém, não se submetendo aos horários que a natureza lhe impõe. Muitas tarefas podem ser executadas à noite, como preparação de ração, trabalhos domésticos e atividades de lazer. Os trabalhos da casa ficam facilitados, através do uso de eletrodomésticos, liberando-se tempo para trabalhar no campo e com isso aumentar a renda familiar.

A realização de atividades noturnas, propiciada pela chegada da energia elétrica, viabiliza outras formas de relacionamento social, facilitando a formação de escolas noturnas e associações comunitárias, que podem reunir-se mais facilmente.

Com a chegada da eletricidade, o produtor sente que sua propriedade se valoriza, estimulando a sua fixação na terra e sua vontade de investir, inclusive facilitando a 
contratação de empregados que preferem trabalhar num local que possua os confortos oferecidos pela energia elétrica.

Finalmente, com a eletricidade, o homem do campo tem um incentivo a menos para se deslocar à cidade em busca de maiores confortos domésticos e melhor renda. Percebe-se que, menos que a possibilidade de subsistência, que de alguma forma é conseguida no campo, é mais o desejo do homem do campo de proporcionar conforto e meios de entretenimento e informação à sua família que o leva a deixar a zona rural e mudar para a cidade, buscando o que julga ser a cidadania e contemporaneidade (RIBEIRO, 1993). Além disso, a diminuição do êxodo rural restringe a pressão social na cidade por mais moradias, empregos, saúde e educação. É mais barato manter o homem no campo do que criar mais um posto de trabalho na cidade grande, já superpovoada (LESSA, 1988).

\subsubsection{Eletrificação rural e desenvolvimento}

Os benefícios econômicos da eletrificação rural citados são contestados pela literatura internacional:

PEARCE; WEBB (1987) afirmam que a eletrificação rural não é um catalisador do desenvolvimento rural e que não se pode fazer uma conclusão geral sobre o aumento da riqueza.

FLUITMAN (1983) diz que a eletrificação rural não traz impactos econômicos positivos, sem evidências que sugiram um aumento de renda para os mais pobres.

MUNASINGHE (1990) cita a demanda para utilização de eletrodomésticos, mas conclui que os benefícios podem ser mais apropriados pelas manufaturas urbanas. Cita 
também a tendência da eletrificação rural ser utilizada para beneficiar as pessoas mais ricas e influentes da área rural.

FOLEY (1992) diz que a eletrificação rural não traz benefícios para os mais pobres e que só propiciará o desenvolvimento econômico se existirem outras précondições, relativas à infra-estrutura.

A análise que esses autores fizeram partiu da implementação de programas de eletrificação rural em diversos países. Todos esses programas foram implementados tratando-se a questão da eletrificação rural de maneira isolada, como se por si só ela fosse suficiente para desenvolver o meio rural. A energia elétrica sozinha não traz, certamente, uma imediata elevação no nível de renda do pequeno produtor rural. Isto se dá ao longo do tempo, como resultado não só da eletrificação, e sim de um programa integrado de desenvolvimento rural, que envolva acesso a créditos, assistência técnica, melhoria de estradas e escolas, etc. Mas, sem energia elétrica, as possibilidades de desenvolvimento econômico no campo tornam-se bem mais reduzidas, podendo estagnar as possibilidades de uma área que reunisse pré-condições para isso. A Companhia Estadual de Energia Elétrica (CEEE) verificou que, após cerca de quatro anos da implantação da eletrificação rural, surgiu uma nova demanda por ligações da ordem de 50 \%. Averiguações de campo mostraram que estas ligações são decorrência do surgimento de novos domicílios ou empreendimentos (armazéns, bares, postos de gasolina, etc.), indicando que a eletrificação deve provocar um aumento das oportunidades de emprego na região (RIBEIRO; SANTOS, 1994). 


\subsubsection{Como eletrificar?}

Há diversas alternativas que podem ser consideradas em estudos de eletrificação rural. Pode-se estender a rede de distribuição de energia elétrica existente, fazer a geração através de conjuntos motogeradores movidos a diesel, ou utilizar fontes renováveis com os recursos existentes no local, como micro, mini e pequenas centrais hidrelétricas, centrais solares ou conjuntos solares individuais, uso de energia eólica ou de biomassa, etc. Todas essas alternativas devem ser consideradas, fazendo-se um estudo de adequação do perfil do consumidor que se deseja atingir com o serviço energético necessário. Um estudo econômico é imprescindível para determinar qual é a alternativa mais viável para a região.

Em regiões ou países com grande malha de distribuição de energia elétrica espalhada, a extensão da rede existente é, na prática, a alternativa preponderante, pelas vantagens da maior disponibilidade energética e existência de uma engenharia mais consolidada. Nesse estudo, vai-se focalizar as implicações decorrentes da opção por essa alternativa de se fazer eletrificação rural.

A eletrificação rural por extensão de rede é parte do sistema de distribuição de energia elétrica e, como tal, está em constante mutabilidade em termos de potência requerida e número de consumidores. Assim, dependendo do perfil de carga de determinada região a ser estudada, pode-se utilizar diversos padrões de configuração de rede e uma grande variedade de equipamentos.

A correta configuração do sistema de distribuição de energia elétrica, levando em conta todas as alternativas existentes, é um dos fatores fundamentais que pode levar 
ou não à viabilidade de eletrificação. Portanto, é necessária uma análise dos padrões existentes:

- trifásico: é o sistema mais caro e também o mais confiável, utilizado normalmente para servir grandes e médias propriedades, povoados e cidades com características de alta densidade de carga. Deste modo, não é o mais indicado para eletrificar regiões cuja densidade de carga é baixa, pois, neste caso, os custos de implantação por consumidor tornam-se bastante elevados;

- bifásico: constitui-se de dois condutores fase, derivados de uma rede trifásica, para atender um suprimento monofásico. É bastante utilizado na França, onde é construído com estruturas idênticas às usadas para o sistema trifásico, com a omissão do condutor no topo do poste, facilitando depois a conversão para o sistema trifásico;

- monofásico com fio neutro: é muito utilizado no sistema de eletrificação rural norteamericano, tendo como vantagens a eliminação de cruzetas e ferragens, a simplificação da construção, a eliminação de um isolador de alta tensão por poste e a utilização de estações transformadoras mais simples e baratas. No estado de São Paulo, a Eletropaulo utiliza esse sistema de forma generalizada na área rural;

- monofásico com retorno por terra (MRT): este sistema utiliza apenas um condutor simples, com a terra servindo como caminho de retorno para a corrente. Foi utilizado primeiro na Austrália, e depois em países como Nova Zelândia, Canadá e Rússia, que possuem grandes áreas com densidade de carga baixa. É o sistema mais econômico, principalmente se for utilizado com materiais adequados, como postes de madeira, condutores de aço, transformadores compactos e construção em regime de mutirão, podendo assim ser viabilizado para populações mais pobres. A CESP possui instalações nesse sistema em São Paulo. 


\subsubsection{A situação brasileira}

Os dados a respeito da eletrificação rural no Brasil, ou, de modo geral, dados sobre a área rural, são, em geral, inexatos e muitas vezes conflitantes, tornando difícil uma visão da realidade da eletrificação rural e o planejamento de políticas competentes.

Segundo relatório da COOPERS \& LYBRAND (1997), consultoria contratada pelo Ministério de Minas e Energia para realizar o projeto de restruturação do setor elétrico brasileiro, o Brasil apresenta índices muito baixos de penetração de energia elétrica no meio rural. Apesar de reconhecer que os números e critérios variem dependendo da fonte, concorda que os índices obtidos são muito baixos.

Existem, segundo a Eletrobrás, mais de quatro milhões de propriedades rurais sem energia elétrica, com um grau de atendimento (inferior a 30 \%) comparável ao dos Estados Unidos na década de 30, quando iniciaram-se esforços intensivos de eletrificação através da REA (Rural Electrification Administration) e das cooperativas de eletrificação rural. A tabela 2 mostra os dados disponíveis, estado a estado. Embora os números sejam do início da década, não há mostras de que tenha havido alterações significativas desde essa época.

Esses números referem-se à propriedades rurais. Uma distinção importante a ser feita é entre propriedade rural e domicílio rural. Uma propriedade rural pode ou não ser habitada, enquanto um domicílio rural geralmente o é. Uma propriedade rural pode ter vários domicílios em seu interior ou apenas um domicílio, ou nenhum.

Tabela 2

Situação da Eletrificação Rural no Brasil

NÚMERO DE NÚMERO DE

PORCENTAGEM

ESTADOS

PROPRIEDADES PROPRIEDADES RURAIS

DE 


\begin{tabular}{|c|c|c|c|}
\hline & RURAIS & ELETRIFICADAS & ELETRIFICAÇÃO \\
\hline Acre & 52.124 & 902 & 1,73 \\
\hline Amapá & 4.938 & 105 & 2,10 \\
\hline Amazonas & 112.806 & 1.566 & 1,39 \\
\hline Pará & 281.106 & 2.112 & 0,75 \\
\hline Rondônia & 64.372 & 1.283 & 1,99 \\
\hline Roraima & 4.429 & 236 & 5,33 \\
\hline Tocantins & 70.201 & 4.212 & 6,00 \\
\hline Alagoas & 132.106 & 15.053 & 11,04 \\
\hline Bahia & 722.758 & 57.170 & 7,90 \\
\hline Ceará & 298.496 & 59.679 & 19,80 \\
\hline Maranhão & 598.315 & 28.694 & 4,70 \\
\hline Paraíba & 189.317 & 15.216 & 7,93 \\
\hline Pernambuco & 364.191 & 51.315 & 14,01 \\
\hline Piauí & 291.624 & 15.168 & 5,15 \\
\hline Rio Grande do Norte & 119.271 & 63.605 & 52,94 \\
\hline Sergipe & 103.831 & 12.728 & 11,65 \\
\hline Distrito Federal & 16.653 & 6.003 & 37,50 \\
\hline Goiás & 103.650 & 39.698 & 35,41 \\
\hline Mato Grosso & 69.440 & 9.526 & 13,04 \\
\hline Mato Grosso do Sul & 57.341 & 17.493 & 29,82 \\
\hline Espírito Santo & 79.416 & 40.629 & 51,16 \\
\hline Minas Gerais & 524.556 & 278.167 & 41,68 \\
\hline Rio de Janeiro & 95.353 & 28.641 & 29,47 \\
\hline São Paulo & 300.582 & 181.591 & 60,30 \\
\hline Paraná & 470.982 & 279.190 & 59,36 \\
\hline Rio Grande do Sul & 490.591 & 266.258 & 54,29 \\
\hline Santa Catarina & 240.324 & 196.007 & 81,68 \\
\hline BRASIL & 5.858 .773 & 1.669 .247 & 27,49 \\
\hline
\end{tabular}

Fonte: SEN - PRODEEM, 1991. In COOPERS \& LYBRAND, 1997.
Quando se considera a energia elétrica como um fator de bem-estar social, fundamental para a melhoria de sua qualidade de vida, a eletrificação de domicílios rurais é também um dado importante. Em 1996, o Instituto Brasileiro de Geografia e 
Estatística (IBGE) identificava 33,1 \% dos domicílios rurais brasileiros sem iluminação elétrica, proveniente de conexão à rede ou não, enquanto 98,9 \% dos domicílios urbanos dispunham de iluminação elétrica.

De qualquer modo, os dados mostram que ainda há um grande déficit na eletrificação rural no Brasil, cujas causas são mostradas em seguida.

\subsection{Aspectos políticos da eletrificação rural}

Uma questão básica, colocada freqüentemente nos estudos sobre o tema da eletrificação rural, é sua viabilidade. Como visto anteriormente, a literatura internacional coloca em dúvida se a eletrificação rural é realmente um vetor de desenvolvimento econômico. Porém, esses mesmos autores afirmam que a qualidade de vida de quem obteve a energia elétrica, através de programas de eletrificação, sofre impactos positivos e significativos.

PEARCE; WEBB (1987) mostram evidências positivas como aumento de horas na escola, melhor iluminação com maior número de horas disponíveis para o trabalho, redução da poluição do ar causado pelas lâmpadas de querosene, aumento da segurança pessoal nas ruas iluminadas por lâmpadas elétricas, aumento das horas de lazer, liberação das mulheres do trabalho pesado para pequenos ofícios e outras atividades produtivas.

FLUITMAN (1983) diz que os consumidores ganham com os benefícios da iluminação e entretenimento, com evidências positivas da utilização da eletricidade particularmente na iluminação, educação, contatos sociais e num maior número de horas possíveis de se trabalhar. 
MUNASINGHE (1990) fala que os consumidores percebem uma significativa melhora nas condições de vida, principalmente pelo aperfeiçoamento da iluminação; estão dispostos a pagar mais pela eletricidade do que pagavam pelo querosene; tem acesso a entretenimento via TV e rádio; agricultores relatam o aumento da segurança e da ordem em relação a crimes, furtos e uma maior proteção contra animais perigosos e cobras.

FOLEY (1992) cita o grande aumento nos padrões de vida. Há maior utilização de equipamentos domésticos aliviando o trabalho penoso. A higiene é beneficiada pela disponibilidade de refrigeração para alimentos e pela água fervida. Há aperfeiçoamento nos modos de entretenimento e possibilidade de melhora nos serviços de saúde e educação, mas estes são prejudicados pela falta de suprimentos essenciais e de pessoal especializado.

O relato de Tendrih, analisando os impactos sócio-econômicos de três projetos pilotos de eletrificação rural no Brasil, evidencia o grande impacto que a eletricidade teve na vida dos beneficiários:

"Todo lugar ficou diferente, a paisagem ficou bem diferente com a energia elétrica, você de noite não anda mais no escuro, você tem mais lazer, é mais animado para todos...”

"A energia no campo muda tudo. Eu encaro a campanha como um conforto da cidade. Morar aqui com energia é a mesma coisa que a cidade. Você tem uma televisão a cores na cidade, eu posso ter aqui; você tem um freezer, eu também posso ter... o que tiver lá, eu posso ter aqui... então por que eu vou sair daqui?”

"Era tudo mais difícil, com mais dificuldade. Depois que botaram a luz, tudo mudou, melhorou muito. Até a vida assim, de dentro de casa, a vida, tudo” (TENDRIH, 1990, p. 97ss).

Como, então, desprezar este componente, como tem sido feito, em decisões de eletrificação por extensão de rede? É fácil para quem vive na cidade, desfrutando dos 
confortos propiciados pela energia elétrica, decidir se é viável ou não para o homem do campo ter eletricidade. A literatura e a experiência pessoal do autor mostram que, quando solicitados a opinar, de nenhuma forma a pessoa que vive na zona rural recusa a energia elétrica; ao contrário, a vê como um bem indispensável que irá valorizar a sua propriedade e melhorar sua vida. Nas pesquisas de campo realizadas pela Universidade de São Paulo dentro do programa "Luz da Terra", quando indagados, os interessados sempre demonstravam grande interesse na energia elétrica:

Mongaguá: em todas as residências visitadas era feita a pergunta: "A luz é para quando?”. Cada morador rural mostrava contentamento com a vinda da eletricidade: "quando a luz chegá nóis vamo tá no céu”. Os moradores rurais mostraram bastante disposição para o mutirão. Alguns locais de passagem da linha estavam limpos com árvores derrubadas e pouco mato. A moradora pede: “moço, aprova tudo lá que a gente precisa de luz. Deus tá do nosso lado”.

Itararé: o Sr. Alceu foi e telefonou várias vezes no escritório da CESP de Itapeva para pedir agilidade na instalação da luz. Ele faz um apelo: "tragam logo a luz para que não nos tornemos sem-terra”. Os moradores da região estão pedindo pela energia há mais de vinte anos (...). Um morador da comunidade da Serrinha diz ter urgência para a instalação da luz, pois precisa fixar trabalhadores em suas terras. Pretende montar uma leiteria na propriedade e colocar um triturador para moer alimento para o gado.

Propõe-se, então, uma inversão dessa questão, que pode ser colocada na seguinte afirmação: é necessário levar a energia elétrica à zona rural, com o fim primeiro de melhorar a qualidade de vida do homem do campo. Com base nessa afirmação, que é adotada como diretriz deste trabalho, cabe então discutir os modos de viabilizar o acesso à energia elétrica a todos os cidadãos da zona rural e as razões que levaram o Brasil a índices tão baixos de eletrificação; razões essas que, como RIBEIRO (1993) mostra, são essencialmente políticas.

Não se pode pensar também a questão da eletrificação rural sem perceber que ela faz parte da política energética geral; que está inserida no contexto do processo de desenvolvimento de cada país. Da mesma forma, o modo de enfrentamento da questão 
social das nações interfere, e grandemente, nas políticas de eletrificação rural adotadas por elas.

Logo, para compreender a questão da eletrificação rural no Brasil, é necessário analisar o seu modelo de desenvolvimento. Em breves palavras, o grande surto desenvolvimentista brasileiro, particularmente na área energética, foi marcado pela interferência direta do Estado na formulação das políticas vigentes, através de empresas estatais, sejam federais, como a Eletrobrás e Petrobrás, sejam estaduais, como as concessionárias de distribuição de energia elétrica, que ficaram com a função de planejar e implementar a maior parte dos sistemas de distribuição urbanos e rurais.

Esse modelo de implementação de políticas de eletrificação rural adotado, centrado nas concessionárias, é a principal causa da situação dos baixos índices da eletrificação rural brasileiros. Como o Brasil sempre foi governado por uma parcela da sociedade que não tem interesse ou não consegue resolver as questões de atendimento às necessidades básicas de toda a população, as políticas adotadas pelo Estado na eletrificação rural, através de suas empresas, privilegiaram sempre critérios outros que não o aspecto da melhoria da qualidade de vida, excluindo uma grande parcela da população do acesso à energia elétrica.

\subsubsection{A omissão do Estado, a omissão da concessionária}

No Brasil, as políticas de eletrificação rural que foram adotadas fizeram parte de um modelo de desenvolvimento que privilegiava o crescimento econômico, em detrimento da distribuição de riqueza e que concentrou renda, terra e disponibilidade energética. No campo, a prioridade foi para o atendimento de grandes produtores 
através de sistemas trifásicos, em tudo semelhantes aos urbanos. Esta concentração pode ser evidenciada através de alguns dados:

- uma análise da distribuição de cerca de 70.000 consumidores rurais atendidos pela CPFL mostra que a sua média de consumo global situa-se em torno de 957 kWh/mês/consumidor. Desse universo de consumidores, 14 \% tem consumo inferior a $10 \mathrm{kWh} / \mathrm{mês,} 20$ \% tem consumo inferior a $80 \mathrm{kWh} /$ mês e mais da metade (53 \%) apresenta consumo inferior a 200 kWh/mês, numa média de apenas 120,7 kWh/mês, número bem distante da média global apresentada, evidenciando o caráter regressivo do consumo, fortemente concentrado nas mãos de grandes consumidores (EPUSP, 1989);

- analisando o perfil de consumo do estado do Rio Grande do Sul, numa pesquisa conduzida dentro do convênio Universidade de São Paulo/Secretaria da Ciência e Tecnologia de São Paulo, verifica-se que a maior parte dos consumidores (93\%) possuíam propriedades com até 100 ha, mas absorviam apenas $58 \%$ da energia demandada pelos estabelecimentos agropecuários gaúchos. Por outro lado, os estabelecimentos com mais de 100 ha, apesar de representarem somente $7 \%$ do total de informantes, utilizaram $42 \%$ da energia consumida no estado, no ano de 1980 (EPUSP, 1989).

Sendo o grande proprietário de terras o grande consumidor de eletricidade no campo, há uma apropriação, por parte dele, dos subsídios destinados às tarifas de energia elétrica concedidos aos consumidores rurais, gerando ainda mais concentração de renda. 
Não houve, dentro das políticas governamentais para o campo, programas destinados ao desenvolvimento rural que integrassem o aumento da produção com a melhoria da qualidade de vida da população rural. Ao contrário, as políticas de modernização e desenvolvimento agrícola envolvendo mecanização, uso de fertilizantes e insumos químicos em grandes fazendas acentuaram ainda mais o fenômeno do êxodo rural.

Essa inexistência de programas de desenvolvimento rural integrado teve, e ainda tem, seus reflexos na eletrificação rural, cujas decisões são tradicionalmente relegadas ao setor elétrico, quando, como mostram as experiências internacionais, deveriam fazer parte de um programa global de desenvolvimento amparado pela sociedade, através do Estado.

O Estado, então, não exercendo seu papel de coordenador de políticas de desenvolvimento voltadas à população de baixa renda, simplesmente ignora a questão da eletrificação rural, repassando o problema às concessionárias. Estas, por sua vez, relegam o problema aos seus setores de distribuição, que encaram a questão como eminentemente técnica, sem considerar os aspectos sociais envolvidos. Assim, um problema que deveria fazer parte de uma política geral determinada pelo Estado, representando o conjunto da sociedade, é na realidade submetida aos interesses díspares de diversos setores de diversas concessionárias.

Na concessionária, a eletrificação rural é tratada como uma extensão dos serviços prestados ao consumidor urbano, com o agravante de que o fato dos consumidores rurais a serem atendidos terem cargas pequenas e dispersas faz com que o custo de instalação seja mais alto e propicie menor retorno em tarifação de energia consumida. A utilização de padrões, sistemas e materiais simplificados, que poderia 
viabilizar o custo de instalação para o consumidor, encontra resistências, muitas vezes injustificadas, por causa da comparação com padrões de excelência urbanos.

Dentro da concessionária, então, a responsabilidade de implementação de uma política social é delegada ao engenheiro de distribuição, cuja cultura é a da não aceitação de padrões simplificados e menos confiáveis, porém mais baratos. O impacto da eletricidade no campo é menosprezado, fruto da falta de assessoria especializada e da própria formação do engenheiro, não voltada a esses aspectos. Como afirma Ribeiro:

"A discussão entre a opção pela melhor qualidade ou um atendimento mais amplo, ainda que se queira restringi-la a aspectos físicos e formais da engenharia, não se esgotará. Ficará incompleta, pois há considerações econômicas e sociais que o engenheiro não poderá ignorar quando investido no papel de funcionário delegado pelo estado para operar um poder público. Ou seja, mesmo na discussão estritamente técnica, no momento de falar do material que vai ser usado, no tipo de ligação, e da qualificação da mão-de-obra, ainda nesse momento há um apelo político muito significativo. Mais que político, há um fator menos racional no mecanismo de tomada de decisão técnica. O corpo técnico responde a uma ideologia conservadora não expressa, porém, capaz de impedir mudanças de concepções tecnológicas.” (RIBEIRO, 1993, p. 91)

Na verdade, no meio de toda essa cadeia é o engenheiro de distribuição que acaba com a responsabilidade de decidir a política de eletrificação rural, responsabilidade essa que ele não deveria ter. Pelo menos não sozinho.

Cabe destacar, também, os interesses não explícitos que conspiram contra a eletrificação rural, como lobbies de fabricantes e empreiteiras contra materiais e técnicas alternativas e ainda as alterações das relações de poder locais advindas de um processo amplo de eletrificação rural, que pode contrariar interesses econômicos e políticos já estabelecidos (um exemplo disso é a possibilidade de os pequenos produtores rurais conseguirem irrigar suas terras, reduzindo sua dependência da água do grande proprietário, que deste modo vê sua influência econômica e política reduzida). 


\subsubsection{Como, então, haver eletrificação rural?}

A negação de todos os pontos abordados no item anterior é necessária, mas não suficiente, para a realização da eletrificação rural. A vontade da sociedade, expressa através de um governo que consiga perceber a importância do tema, é o primeiro e mais importante passo na direção de romper as barreiras ao atendimento do pobre rural. A priorização da eletrificação rural vai ser sempre objeto de uma decisão política, que privilegia determinados temas em detrimento de outros.

Essa vontade política pode ser criada a partir da percepção da urgência do tema, por motivos ideológicos ou por pressão dos grupos interessados. É papel também da Universidade despertar essa vontade política, influenciando e assessorando os governos em sua consecução. Vencido esse passo, passa-se para outro, igualmente importante, que é o de planejar e implementar uma política de eletrificação rural. Neste ponto, a viabilização de recursos, a identificação das demandas reprimidas e o envolvimento de todos os agentes, do Estado e da sociedade, são fundamentais para o sucesso da política. Conforme Ribeiro:

"o estado (...) tem a obrigação de incluir todos os cidadãos, inclusive os pobres rurais, nas metas de atendimento dos serviços públicos. Para tanto, é necessário um modelo de eletrificação com objetivo específico de atender pequenos produtores rurais. É fundamental utilizar uma engenharia de eletrificação rural de baixo custo, desenvolver um esquema de crédito adequado ao público pretendido, e envolver outros atores além da concessionária, em um arranjo institucional que privilegie a participação comunitária”. (RIBEIRO, 1997, p. 17)

Aliás, a participação comunitária é um ponto fundamental na implantação de políticas que visem o desenvolvimento rural sustentável. A Agenda 21 afirma, em seu capítulo 32, que 
"a descentralização das tomadas de decisões, entregando-as a organizações locais e comunitárias, é a chave para mudar o comportamento da população e implementar estratégias agrícolas sustentáveis" (CONFERENCIA DAS NAÇÕES UNIDAS SOBRE MEIO AMBIENTE E DESENVOLVIMENTO, 1992, p. 400).

O BNDES e a Universidade de São Paulo vêm se empenhando, já há dez anos, no estudo e aplicação de um modelo de eletrificação rural que contemple a participação comunitária, que descentraliza boa parte das decisões, que permita que todos, inclusive o pobre rural, tenham acesso à eletricidade. Esse modelo requer, sobretudo, que haja uma decisão política para sua implantação, que se confronte interesses explícitos e nãoexplícitos dentro das concessionárias e do Estado. Este modelo foi aplicado no Rio Grande do Sul, com sucesso. Este mesmo modelo se quis ver implantado em São Paulo, e é a prática dessa implantação que o presente trabalho se propõe a analisar. 


\section{CAPÍTULO 3 - ESTABELECENDO UMA POLÍTICA DE ELETRIFICAÇÃo RURAL}

\subsection{A Universidade identifica uma demanda social, mostra soluções, identifica uma fonte de recursos e apresenta ao governo uma proposta de política pública}

No início de 1995, pesquisadores da Escola Politécnica da Universidade de São Paulo levaram ao Secretário de Energia recém-empossado, também professor da Universidade de São Paulo, do Instituto de Eletrotécnica e Energia, uma proposta trazida do BNDES.

Propôs o BNDES que a Universidade mostrasse ao governo de São Paulo que seria possível adaptar o modelo de eletrificação aplicado ao Rio Grande do Sul, denominado modelo BNDES/USP, às condições peculiares do estado de São Paulo, e informasse que o BNDES poderia colocar os recursos financeiros necessários à disposição dos proprietários rurais. E, mais importante, demonstrasse a relevância social de um projeto de eletrificação que pudesse atender a todos os habitantes rurais sem exclusão de qualquer segmento social.

Foi nomeada uma comissão para estudar o problema e elaborar um projeto a ser proposto ao BNDES, denominada Comissão Estadual de Eletrificação Rural (CEER).

A Universidade de São Paulo tinha assento junto a essa comissão. Na prática, com relação à política a ser adotada, falava apresentando as linhas traçadas pelo BNDES, mantendo estreito contato com a Superintendência de Infra-estrutura daquela agência. 
O texto de RIBEIRO; SANTOS (1994) publicado na Revista do BNDES, intitulado "Política de eletrificação rural - superando dilemas institucionais" serviu de base para os trabalhos desta comissão. Esse texto resume os trabalhos da Escola Politécnica relativos a esse tema, condensando a tese de livre-docência de RIBEIRO (1993) intitulada “Eletrificação Rural de Baixo Custo", e apresenta as linhas gerais do modelo BNDES/USP tal como foi aplicado no Rio Grande do Sul, inclusive trazendo avaliação dos resultados.

O programa gaúcho foi planejado para atender 4.000 famílias e terminou por fazer 6.500 ligações a um custo médio de US\$ 735,00 (BANRISUL, 1993). Chamou-se PROLUZ e teve a Universidade de São Paulo como assessora técnica e como avaliadora. Foi claramente definida uma linha filosófica e competia à Universidade de São Paulo analisar cada projeto elétrico verificando se era compatível com a política proposta pelo BNDES. A liberação do financiamento dependia da aprovação da Universidade. Assim definiu o BNDES, pois havia naquele cenário a possibilidade de conflitos entre a concessionária e a coordenação do programa, de responsabilidade do Banco de Desenvolvimento do Rio Grande do Sul (Badesul). Competiria à Universidade mediar eventuais conflitos, representando o BNDES. Para tanto, foi feito um contrato de pesquisa e prestação de serviços entre Universidade de São Paulo e Badesul, depois Banco do Estado do Rio Grande do Sul (Banrisul).

O BNDES, anteriormente, havia financiado um projeto piloto no município de Palmares do Sul, prevendo a aplicação de tecnologia desenvolvida na Escola Técnica Federal de Pelotas, baseada no uso do sistema MRT, poste de madeira, condutor de aço zincado, chave repetidora, descarregador de chifre, transformador ruralito, engate espiralado e construção de redes pelo sistema de mutirão (ROSA et. al., 1993b). O 
BNDES achou que a experiência tivera bons resultados e pretendeu estendê-la para outras áreas do Rio Grande do Sul. A concessionária local, a CEEE, não permitiu.

Por pressão da Diretoria do Desenvolvimento Rural do BNDES, o governador do estado, e hoje senador Pedro Simon - em pessoa - mediou o conflito. Obrigou a CEEE a sentar-se à mesa com o pessoal de Palmares, formando uma comissão para apresentar uma norma de eletrificação rural simplificada em um mês. Em dois meses estava aprovada a NTD-025 da CEEE, norma que presta bons serviços até hoje, e que também foi apresentada ao governo de São Paulo como base técnica para a política do BNDES para eletrificação rural de baixo custo.

O que o BNDES, no seu papel de interferir na realidade nacional propondo políticas de desenvolvimento, definiu como ingredientes fundamentais para se projetar um política de eletrificação rural com o objetivo de incluir toda a população rural, sem exclusão das camadas sociais rurais mais pobres, com abrangência em todo o território do estado de São Paulo, foi:

1) Vontade política do governador.

2) Coordenação a cargo de uma agência que não fosse uma concessionária de energia.

A propósito, convém lembrar que os principais autores, ao analisar o sucedido com projetos extensivos de eletrificação rural em países em desenvolvimento promovidos por agências de financiamento internacionais (BIRD, Asian Bank, USAID, etc.) são claros ao afirmar que deixar a gestão para a concessionária não é o meio de se obter sucesso com uma política de eletrificação rural. A gestão deve ficar com uma agência que pense no desenvolvimento da região. 
FOLEY (1993) fala do dilema de concessionárias entre atender clientes que julga mais importantes e os clientes rurais e diz que a eletrificação rural introduz uma situação de desprestígio aos técnicos que dela cuidam, no mundo todo, principalmente no terceiro mundo por causa das restrições econômicas, técnicas e das enormes carências da população. RIBEIRO; SANTOS (1994) mostram que essa observação é muito apropriada ao caso brasileiro que, aliás, tem um pormenor que o diferencia da maioria dos países subdesenvolvidos: dispõe de energia elétrica com base em fontes renováveis em grande abundância, por causa de seu parque hidroelétrico gigantesco.

3) Projetos elétricos de baixo custo, privilegiando o sistema MRT.

4) Unificação de normas e de método de apropriar custos em todas as áreas do estado.

5) Financiamento direto ao consumidor final.

6) Acompanhamento pela Universidade de São Paulo.

Foi apresentado um projeto ao BNDES que se intitulou Projeto “Tem Luz?”.

Tal título revelava uma intenção dupla. A primeira era causar um impacto dialético na população, fazendo-a questionar a si e ao Estado dos motivos de ainda não ter luz em casa. A segunda era induzir técnicos a um projeto de atendimento principalmente voltado para a demanda por energia doméstica, para o conforto no lar. O título favorecia um ambiente propício para estar se pensando no surgimento de um segundo projeto, voltado para cargas de maior porte: o Projeto “Tem Força?” que, apesar do BNDES garantir que seria de concepção imediata, baseada em linhas de crédito já consagradas na instituição, jamais moveu o interesse de qualquer planejador em São Paulo. 


\subsection{O Projeto “Tem Luz?”}

É importante analisar o contexto político que deu forma à política de eletrificação rural em São Paulo, nos primeiros meses do governo que se iniciou em 1995.

Um partido que se imaginava ser de centro-esquerda aliou-se taticamente a um partido que se dizia centro-direita, ganhando a eleição de um candidato de apelo populista. É interessante lembrar que, no plano nacional, o adversário era outro. Então, essa aliança se amalgamou com um programa de interesses definidos.

A Secretaria de Agricultura e Abastecimento ficaria com o presidente do partido mais de direita, como forma de garantir o apoio da conservadora classe de empresários rurais. E havia a garantia que o governo teria que corresponder a esse apoio promovendo a irrigação de 100.000 hectares de terras para produção agrícola. Essa garantia era consolidada pela promessa de que o Partido da Frente Liberal (PFL) teria para si duas diretorias de concessionárias estatais da área de energia. Também, no programa de governo, estava assentado que o atendimento de eletrificação rural passaria dos então 60 \% para 80 \%, promovendo energia para o levante de água.

O governo tentou criar na sociedade anônima CESP uma diretoria denominada Diretoria de Eletrificação Rural e Irrigação, destinada ao que se chamava "cota do PFL”. Não conseguiu formalizar isso. Todavia, embora sem respaldo na burocracia administrativa oficial, essa Diretoria foi constituída, com um grupo de técnicos de alta experiência política e operacional. Havia o Diretor, havia a equipe, havia o espaço, havia bons recursos operacionais e havia destinação orçamentária. Só não havia a Diretoria nos regimentos da sociedade anônima, o que levava a equipe a se desdobrar 
em ações que demonstrassem a importância política de seus trabalhos, com a finalidade de que o Conselho de Administração pudesse aceitá-la. Até mesmo sua denominação sofreu várias alterações durante as tentativas. Ora o enfoque era na Irrigação, ora na Eletrificação Rural.

O Projeto “Tem Luz?”, nesse contexto, era um trabalho tipo salvação da lavoura, pois fazia a projeção da atuação da Diretoria de Eletrificação Rural e Irrigação a todo o território do estado de São Paulo, levando um programa que se imaginava ser a maior ação social de um governo sem dinheiro, e sem haver desembolso direto de recursos estaduais. Projetava junto o Secretário de Agricultura e Abastecimento, um político que demonstrava sensibilidade social, pecuarista de renome, ex-ministro, presidente do PFL paulista e aspirante a vôos políticos mais amplos.

Essa Diretoria tinha grande mobilidade e seu titular era um executivo que soube entender o significado dos objetivos do BNDES com relação à não exclusão social.

Embora o Projeto “Tem Luz?” fosse de responsabilidade da Secretaria de Energia e por ela coordenado, seu principal operador era esse executivo, que tinha uma estrutura de apoio muito eficiente, com condições de efetivamente atuar em todos os municípios.

Essa disponibilidade operacional, e a grande disponibilidade pessoal dos operadores, foram apresentadas ao BNDES como instrumentos da eletrificação rural em São Paulo.

A capacidade operacional e a agilidade política demonstradas pelo PFL foram marcantes na fase inicial de planejamento da política de eletrificação rural, principalmente na escolha e articulação dos atores. E se contrapunha a uma certa 
dificuldade de transformar decisões em atos do grupo de técnicos da Secretaria de Energia.

Por um lado, estava um executivo hábil em suas funções, que era quem levava a cabo as ações da Energia na área do interior do estado. Mas, apesar da visível lealdade na condução de suas ações políticas, e apesar de estar levando para os municípios a mensagem política do Secretário de Energia juntamente com as propostas programáticas de sua pasta, era sempre lembrada sua condição de ser componente da "cota do PFL no governo Covas”. Havia uma desconfiança mais ou menos velada por parte do grupo da Secretaria de Energia de que seu PSDB poderia estar perdendo espaço para o grupo instalado na Secretaria de Agricultura. Por outro lado, a natureza política da equipe da Energia era muito mais complicada e com menor experiência gerencial. O Secretário dizia “vamos fazer” e o grupo ficava imóvel até o Secretário determinar quem, quando e como era para fazer. Enquanto isso, a Secretaria de Agricultura agia prontamente oferecendo suporte ao projeto, procurando aumentar sua responsabilidade e sua visibilidade.

Um outro capítulo difícil foi a escolha do agente financeiro. O ideal seria um banco estadual de grande capilaridade no interior do estado, com experiência de crédito a tomadores de baixa renda e crédito rural e credenciado como agente do BNDES. Tal como o Banespa, naquele momento um nome impronunciável no setor financeiro do BNDES, por causa da dívida deixada pelo governo anterior. O outro banco estadual paulista, a Nossa Caixa Nosso Banco, não era credenciado para operar créditos do BNDES.

Foi tentado o envolvimento de bancos particulares, que não se interessaram. Chegou-se a pensar nos bancos federais. O Banco do Brasil apresentou dificuldades às 
operações do BNDES e foi descartado. Havia o Banco Meridional, que tinha sido adquirido pelo governo federal, para privatização logo mais. Esse assunto estava sendo discutido quando surgiu a possibilidade de viabilizar o credenciamento da Nossa Caixa Nosso Banco para especificamente operar os créditos relativos à eletrificação rural. Um fato interessante à Nossa Caixa, ponto de partida para um credenciamento amplo no futuro.

Todavia, houve certa dificuldade de fazer a Diretoria da Nossa Caixa aceitar um trabalho grande, de poucos ganhos e com público pobre. A Diretoria não queria uma operação de mais de quatro anos de prazo e nem assumir o risco bancário, mesmo ganhando uma taxa - chamada del credere - para fazer isso.

Criou-se um formidável impasse. O governo, maior acionista do banco, aceitou o risco, baseado no histórico de baixíssima inadimplência associada a créditos para eletrificar pequenas propriedades rurais. Porém, a Diretoria forçava que outra instituição estadual - pensava nas concessionárias - assumisse o risco bancário.

Então, surgiu a presença política do Secretário de Agricultura. Ele já assumira os custos de uma operação de equivalência em produto, através do Fundo de Expansão da Agropecuária e da Pesca (FEAP), adiantando-se à Secretaria de Energia que, em princípio, seria o órgão indicado para providenciar essa cobertura, por ser a operação protegida de sua responsabilidade. Havia o desativado Fundo Estadual de Eletrificação Rural (FEER), que ficara não na Energia, mas na Secretaria de Recursos Hídricos, quando do desmembramento daquela.

O Secretário de Agricultura resolveu o impasse colocando sob sua pasta, amparado pelo mesmo FEAP, a cobertura do risco bancário dos mutuários com renda 
inferior a $\mathrm{R} \$ 7.500,00$ de receita bruta familiar anual, equivalente, em 1997, a 5,2 salários mínimos mensais.

Havia um problema legal a ser resolvido e o Secretário de Agricultura prontamente mandou resolver: o FEAP, e a Agricultura, não podem atender a outras pessoas que não sejam agricultores, pecuaristas ou pescadores artesanais. Em outras palavras, a Secretaria de Agricultura só pode atender produtores rurais. Os simples moradores rurais ou os que praticam agricultura de subsistência, ou os “bóias-frias”, por exemplo, não têm o amparo do Estado através dessa Secretaria. O Secretário de Agricultura mandou seus técnicos iniciarem providências para a proposição de uma nova "lei do FEAP”, pela qual o estado estenderia seu interesse e proteção aos moradores da área rural que não fossem produtores.

Então, assim ficou estabelecido: famílias com renda mensal acima de 5,2 salários mínimos teriam crédito com risco assumido pela Nossa Caixa, sem que esta exigisse garantias reais, impensáveis para o público alvo; de 5,2 a um salário mínimo mensal de renda, o FEAP refinanciaria a dívida em caso de inadimplência; abaixo de um salário mínimo, consideradas famílias de baixa renda, a ligação seria responsabilidade do estado. O prazo seria de 72 meses, com carência de seis meses a um ano, sendo permitido que um beneficiário avalizasse o outro, o chamado “aval circular”.

A mudança de posicionamento da diretoria da Nossa Caixa, exigente demais no começo, aceitadora das condições impostas pelo BNDES no fim, refletiu uma ação decidida do governo do estado de São Paulo, dentro do objetivo de não permitir exclusão social na política de eletrificação rural. 
É digno de nota que essa diretoria foi abrandando posições ao longo do tempo, entendendo o significado da eletrificação das propriedades rurais pobres. Já o Departamento Rural da Nossa Caixa sempre teve atitude firme de apoio, viabilizando o caráter social do programa "Luz da Terra".

Em junho de 1995, o BNDES concedeu prioridade ao Projeto “Tem Luz?”. Isto significa que o BNDES aceitou a proposta para estudos e reservou recursos para o programa.

Foram solicitados R $225.000 .000,00$ para o atendimento de 150.000 famílias rurais. A Nossa Caixa Nosso Banco foi apresentada formalmente como agente financeiro interveniente. Inicialmente, o estado de São Paulo se obrigaria com uma contrapartida de $20 \%$ dos recursos aos $65 \%$ de responsabilidade do BNDES, ficando $15 \%$ para a comunidade atendida desembolsar.

Posteriormente, tendo o Secretário de Energia empenhado sua palavra como garantia de que o governo Mário Covas faria a construção das linhas-tronco necessárias por sua conta e por sua conta ligaria as famílias de baixa renda, o BNDES aceitou este comprometimento pessoal do prof. David Zylbersztajn e respondeu elevando sua parte para $80 \%$, ficando ao governo estadual a contrapartida de $5 \%$, a ser contabilizada com o pagamento do trabalho de elaborar os projetos técnicos, a cargo das empresas de energia.

Isto é, o governo de São Paulo não desembolsa recurso para as obras contratadas junto ao BNDES, ficando com as responsabilidades de fazer o projeto, orçá-lo, além das obras de linhas-tronco e do atendimento das famílias mais pobres, através das concessionárias. 
Os $15 \%$ a cargo do interessado podem ser reduzidos ou abatidos se ele se organizar e a comunidade realizar trabalhos não-especializados pelo sistema de mutirão.

O valor de cada ligação foi estimado em $\mathrm{R} \$ 1.500,00$, sendo que apenas $25 \%$ delas poderiam superar esse valor, até o teto de R\$2.500,00. O montante financiado é pago na conta de luz individual de cada família, em 72 meses, com carência de até doze meses, corrigido pela Taxa de Juros de Longo Prazo (TJLP) mais juros de 3,5 \% ao ano. O valor estimado de cada parcela a ser paga é de cerca de $\mathrm{R} \$ 30,00$, equivalente a um aumento de um hectare na produção de milho da propriedade.

\subsection{A descaracterização da política}

As coisas políticas foram se modificando...

O arranjo institucional desenhado pelo grupo coordenado pela Secretaria de Energia em conformidade com o BNDES não chegou a ser completado. Dois atores não puderam desempenhar o papel previsto: a Secretaria de Energia perdeu sua capacidade de operar o programa com independência das concessionárias e a Secretaria de Agricultura não pôde dar sustentação ao enfoque social do programa. Ambos os fatos foram decorrentes das mudanças políticas no governo de São Paulo e a ambas as situações nem a Secretaria de Energia, nem o governo, souberam dar respostas adequadas, no sentido de exercer os papéis combinados com o BNDES.

Os fatos são relatados a seguir.

\section{a) Perda da capacidade operacional da Secretaria de Energia}


Havia uma questão aberta, que era a não oficialização da Diretoria de Eletrificação Rural e Irrigação dentro da organização CESP.

As três concessionárias públicas tinham sua Diretoria de Distribuição de Energia Elétrica. Porém, a eletrificação rural tinha diferentes espaços. Na CPFL estava junto à Diretoria de Distribuição; na Eletropaulo em uma Assessoria da Diretoria de Distribuição. Na CESP, estava em dois lugares.

Os programas de eletrificação rural da CESP, tradicionalmente, eram feitos pela Diretoria de Distribuição, junto ao responsável pela Comercialização. Na prática, a Diretoria de Eletrificação Rural e Irrigação era o braço gestor das operações da Secretaria de Energia, reportando-se diretamente ao presidente da CESP, dando orientação ao projeto “Tem Luz?”, ao qual estavam vinculadas as três concessionárias. Sempre foi uma situação complicada o fato da Distribuição seguir orientação dessa Diretoria não oficial, ambas no âmbito da CESP.

A simpatia da Distribuição da CESP ao projeto “Tem Luz?” pode ser medida pelos nomes que a representavam nas reuniões: dificilmente quem comparecera às reuniões anteriores era a pessoa que estava presente, truncando o processo de planejamento da Secretaria de Energia.

Nesse meio tempo, o Diretor de Eletrificação Rural e Irrigação foi afastado do Projeto “Tem Luz?” como forma de reduzir a influência do PFL no interior do estado. Ao invés de ser substituída, a equipe da Diretoria e ela própria foram desmobilizadas. Sua função, de apoiar a Secretaria de Energia e levar a ação política do governo às lideranças locais, para que essas se mobilizassem, foi esquecida. 
Em seguida, como forma de apagar a influência do PFL no interior do estado veiculada pela eletrificação rural, o nome “Tem Luz?” foi deixado de lado, sendo substituído por “Luz da Terra”. Apagou-se junto a idéia latente do “Tem Força?” e parte do apelo comunitário agregado à pergunta. A instigação inerente à pergunta foi substituída pelo convencional paternalista.

Alguns remanescentes da antiga equipe foram transferidos para a equipe de Distribuição da CESP onde ficaram notoriamente deslocados. Tinha sido montado um grupo de apoio à Secretaria de Energia nas ações de distribuição rural com rara habilidade. Estavam nesse grupo engenheiros de grande experiência e o grupo de apoio era formado por gente da maior competência. Com um detalhe: era gente que estava às portas da aposentadoria. O grupo foi minguando, minguando e quase sumiu.

Dessa maneira, o que sumiu foi a capacidade operacional da Secretaria de Energia no interior: extinguiu-se por aposentadoria de um pessoal que não foi reposto!

Então, foi dessa maneira que o governo Mário Covas não teve meios de operacionalizar o programa de eletrificação que contratou com o BNDES e, na prática, partiu para ações que levaram a direções diferentes da orientação da política desenhada pela Secretaria de Energia.

Por iniciativa do BNDES, o contrato assinado com a Nossa Caixa possui um dispositivo pelo qual o coordenador pode requisitar funcionários e estrutura operacional das concessionárias participantes. Nem assim a Secretaria de Energia conseguiu pessoas e condições para estar presente nos municípios. 
Ainda no começo de 1996, os funcionários da CESP escutavam rumores de que se forçava fazer um programa de eletrificação mais voltado para atender interesses de alguns políticos dentro de relações privilegiadas com algumas empreiteiras de porte.

Não era esse o propósito da Secretaria de Energia, muito menos da política que estava sendo planejada. Preocupada com as possibilidades geradas por essa situação, partiu da própria Secretaria de Energia a iniciativa de colocar expressamente no contrato a ser firmado com o BNDES, ao qual se co-obrigariam as empresas de energia, um dispositivo que impossibilitasse o uso do nome "Luz da Terra" em programas que permitissem ganhos exagerados das empreiteiras, conforme já acontecera em muitas páginas anteriores da história das obras do setor elétrico, em detrimento do cidadão beneficiário, em benefício de grupos políticos.

\section{b) Perda dos instrumentos que garantissem a não-exclusão social}

Havia uma disputa latente no âmbito político da Agricultura, onde se inseria a Diretoria de Eletrificação Rural e Irrigação. Havia uma conceituação legal que atribuía à Secretaria de Agricultura as coisas da eletrificação rural. Em função disto, a Coordenadoria Sócio-Econômica daquela Secretaria buscava maior espaço de atuação, de certa forma disputando com a Diretoria que estava na CESP. Quando a Diretoria foi desmobilizada, a Coordenadoria Sócio-Econômica, órgão que na prática controlava o FEAP, lançou-se reforçando sua influência no Projeto “Tem Luz?” e garantindo a presença política do Secretário de Agricultura.

A Coordenadoria foi assumindo novos papéis, em nome do Secretário, projetando-se como instrumento de apoio à viabilização da política de eletrificação rural da Secretaria de Energia, sempre com um sentido de preocupação social. Foi assim que 
nasceu a idéia de ampliar o alcance do FEAP aos não-produtores rurais. O segmento rural de maior concentração de pobreza é justamente composto pelas famílias que simplesmente vivem no campo praticando agricultura de subsistência, ou nada produzindo. É um povo rural que o planejador do desenvolvimento brasileiro nunca quis enxergar e, sob o mesmo tipo de enfoque desenvolvimentista, a Secretaria de Agricultura e Abastecimento do Estado de São Paulo não tem amparo legal para proteger, através do FEAP.

Convém lembrar que nessa mesma época se discutia a reformulação do Estado brasileiro. Os neoliberais recomendavam que devesse haver "políticas de compensação social” antes da reformulação econômica. O “resgate da dívida social” era necessário ser feito antes do Estado se desfazer de suas empresas de energia elétrica. Dessa forma, a eletrificação do pobre rural feita pelo próprio Estado era vista como forma de reforçar a viabilização da privatização das concessionárias de energia.

A dinâmica política mostra a força da contradição dialética e surge uma situação paradoxal. Os conservadores, naquele contexto, efetivamente atuavam para que a eletrificação rural pudesse contribuir para o resgate da cidadania, com eqüidade. Eles não chegaram, concretamente, a ações efetivas. Todavia, os progressistas que os substituíram não souberam viabilizar o atendimento do pobre não-produtor.

A ruptura veio com a eleição municipal de 1996, quando o PFL foi defenestrado do governo paulista, em virtude de sua aliança com o PPB, partido que tem como principal liderança um inimigo político do governador Covas. Naturalmente, surgiu uma onda buscando anular avanços políticos conseguidos, e essa onda bateu forte na política de eletrificação do governo estadual. 
Todavia, além da onda de desmobilização das coisas do PFL, no processo perdeu-se parte do arcabouço institucional que já havia sido montado para a eletrificação e que, consagrado por um decreto do governador e pelo contrato assinado com o BNDES, não pôde ser corrigido.

O papel que a Agricultura assumira foi parcialmente perdido e o pobre rural que não produz, cria ou pesca comercialmente ficou sem respaldo para o crédito do BNDES.

Em decorrência desses dois grandes golpes e da incapacidade de reação a eles, pode-se afirmar que o programa "Luz da Terra", à época do lançamento, já não correspondia ao modelo combinado com o BNDES.

O arranjo institucional praticado ficou capenga, o que mostra que a vontade política tinha que ser mais firme para que as ações pudessem corresponder ao discurso do governo.

\subsection{As dificuldades institucionais após o lançamento}

Em setembro de 1996 foi lançado o programa "Luz da Terra".

Em julho de 1997, 11 meses depois, foi contratado o primeiro financiamento.

Até 15 de dezembro de 1997, data limite de encerramento da primeira etapa do contrato com o BNDES - e de encerramento do período cuja avaliação dá origem a este trabalho acadêmico - de uma proposta inicial que previa a assinatura de 30.000 contratos de financiamento, foram assinados exatos 1.196 contratos.

Um resultado pífio, para o qual a perda da capacidade operacional da Secretaria de Energia e a perda dos instrumentos que garantissem a não-exclusão social 
contribuíram decisivamente. As ações de campo, descritas no próximo capítulo, e a coordenação do programa não corresponderam ao que foi planejado pelo governo, que não se muniu de instrumentos para cumprir rapidamente o combinado com o BNDES.

No decreto que instituiu o programa, criou-se a Comissão de Eletrificação Rural do Estado de São Paulo (CERESP), com a missão de coordená-lo. É uma comissão de alto nível, cujo presidente é o próprio Secretário de Energia, e que conta com representantes das Secretarias de Agricultura e Abastecimento (SAA), Economia e Planejamento (SEP) e Ciência, Tecnologia e Desenvolvimento Econômico (SCDTE), esta representada pela Universidade de São Paulo.

Essa comissão originou outra, denominada Comissão Executiva (COMEX), composta por um coordenador e membros das instituições envolvidas. Na prática, essa comissão ficou com a tarefa de implantar o programa, com a responsabilidade inicial de fazer com que fossem executadas atividades que o BNDES impôs como obrigação prévia para o contrato ter algum efeito, como a assinatura de contratos entre a Nossa Caixa e as concessionárias, a elaboração de uma norma técnica e de um sistema de apropriação de custos unificados para o programa e a constituição de uma Comissão Técnica (COMTEC) para analisar os processos.

As comissões constituídas eram, e são, comissões de gabinete. A capacidade operacional, desmontada com o desaparecimento da Diretoria de Eletrificação Rural e Irrigação da CESP e pela aposentadoria dos executivos que permaneceram dirigindo a eletrificação rural junto à Secretaria de Energia, não foi reposta. É importante observar que a Secretaria de Energia tem uma relação umbilical com as empresas que controla. A sua sede é num prédio da CESP, a maioria absoluta de seus funcionários é cedida pela Eletropaulo e CESP, boa parte dos recursos para sua manutenção vêm das empresas. 
Na COMEX, as pessoas que coordenavam o programa no período imediato a seu lançamento tinham participado dos trabalhos de formulação da política e planejamento das ações desde seu início. Estavam convencidas que alguns pontos colocados pelo BNDES eram as trilhas que, embora difíceis, levariam o programa através de um terreno muito incerto. O sucesso só viria se o programa fosse guiado por essas trilhas até que a própria prática fosse consolidando apoios e o programa pudesse passar a ser conduzido por suas próprias forças em direção aos objetivos sociais propostos.

O próprio Secretário de Energia estava convencido que esses pontos eram fundamentais à sustentação da filosofia que fora definida; para todos os efeitos a filosofia de eletrificação rural da Secretaria de Energia de São Paulo.

Entre esses pontos, está a convicção de que a concessionária de energia não gosta de fazer eletrificação rural.

Por isso, a coordenação tinha a preocupação de criar condições de impor políticas às concessionárias, aplicando o modelo, mas não tinha força suficiente para isso. Um exemplo foi a determinação do Secretário para que se constituísse uma equipe - nominando quatro pessoas que deveriam ser contratadas - para implantar o programa em campo, mobilizar a sociedade local e organizar as comunidades em torno do processo, com a capacidade de multiplicar as ações, repondo a capacidade de atuação da Secretaria. Essa equipe só conseguiu ser viabilizada, parcialmente, no fim de 1997.

A falta de força política e a mudança na coordenação do programa, no início de 1997, fizeram com que a Secretaria de Energia delegasse a responsabilidade de implantação do programa às concessionárias, que pouco a pouco ganharam mais e mais influência. Nesse momento negou-se o modelo e consolidou-se uma prática capenga, 
que mostrava o quanto as equipes dos setores de Distribuição das concessionárias afrontavam a autoridade do Secretário de Energia.

Outra questão que suscitou muitas discussões foi o atendimento a três condições que o BNDES considerou fundamentais e que o decreto que instituiu o programa obrigava a considerar:

a) a exigência de uso de sistemas de baixo custo;

b) a exigência da elaboração e adoção de uma norma técnica unificada para todas as empresas que aderissem ao programa, correspondente a um sistema compatível com os baixos custos desejados; e

c) a exigência da elaboração e adoção de um sistema único de apropriação de custos, compatível com as metas de baixos custos médios.

Com referência aos aspectos técnicos, enfatizou-se a necessidade de se privilegiar, sempre que possível, o sistema MRT, adotando padrões e metodologia similares à norma NTD-025, da CEEE.

JUCÁ (1998) apresenta as discussões e contradições envolvidas na elaboração da norma técnica para o programa, e analisa as limitações da versão final.

A exigência de uma norma e de um sistema de custos único é explicável. As três principais concessionárias de São Paulo possuem padrões de construção de redes rurais diferentes, e apenas a CESP tinha experiências com redes MRT. Essa diversidade era incompatível com um programa que queria ser de âmbito estadual, tratando igualmente os moradores rurais paulistas que tivessem situações de campo equivalentes. 
O processo de discussão da norma evidencia a resistência das concessionárias em aderir à política proposta. Além do decreto do governador ordenar que houvesse uma norma, o contrato com o BNDES o tinha como condição prévia a ser cumprida para começar a liberação dos créditos. Passados três meses do lançamento do programa, as empresas ainda relutavam em reunir suas áreas técnicas para iniciar os estudos da nova norma. A oposição da CESP era evidente e passou a gerar sabotagem ao "Luz da Terra". Foi apresentado um texto pelo seu Diretor de Distribuição, que se mostrara entusiasmado com o documento. O documento desapareceu e alguns meses depois o coordenador revelava que tinha ficado mofando na gaveta do chefe do departamento de engenharia. Enquanto isso, o prazo do programa estava correndo e nada mais se fazia a não ser aguardar que a gaveta do chefe fosse aberta. Houve quebra de autoridade com a conseqüente substituição de quem a apontou. Isto é o governo de São Paulo.

Por fim, a Secretaria de Energia apresentou uma proposta, que contemplava as diversas alternativas de construção de redes mais baratas, com um roteiro de procedimentos e apresentação de projetos no sistema MRT.

Esta proposta foi apresentada às concessionárias para análise e discussão. Jucá relata esse processo:

"A partir desse momento evidenciou-se, em primeiro momento a natural resistência da concessionária, negando priorizar a análise da norma proposta, desconsiderando a importância social da questão. Em segundo momento, as resistências passaram a ser constatadas nas áreas técnicas das concessionárias pelos engenheiros de distribuição. Esses apoiados na costumeira busca ideológica da excelência dos serviços, sem se prender à redução de custos, negavam discussões fundamentais para a eletrificação rural.

Durante as várias reuniões para esclarecimento e consenso das exigências de simplificações de projetos contidas na norma proposta, constatou-se que os engenheiros estavam discutindo se aceitariam ou não a aplicação do sistema MRT. Chegou-se ao ponto de até a posição do transformador no poste ser motivo de empecilho. 
Estava assim sendo esquecido o objetivo da discussão técnica em se conseguir formas de projetos mais baratos, estava sendo esquecido mais uma vez o objetivo de viabilizar o acesso à energia elétrica das populações rurais carentes. A discussão era focada em mostrar quem tinha mais competência técnica.

Cada empresa se opunha por motivos diferentes: a CESP por possuir uma diretriz para projetos em MRT, apesar de não priorizar esse sistema para a eletrificação rural, fato constatado porque nunca transformou essa diretriz em norma técnica, não aceitava estudar a norma proposta, se esquecendo que os padrões adotados são os mesmos que havia sido propostos pelos RERs da ELETROBRÁS; a CPFL por nunca ter feito experiências com o sistema e considerá-lo inviável em sua área de concessão; a Eletropaulo, justificou que não utilizaria o sistema MRT porque já utilizava o sistema fase-neutro. (...)

Após conseguir o convencimento das áreas de engenharia das concessionárias a aprovar o padrão MRT, o que não significa garantia de que iriam utilizá-lo, surgiu um problema de caráter institucional: as empresas só consideram como norma o sistema e os critérios já testados e de comprovada viabilidade. Como a CPFL e Eletropaulo nunca haviam utilizado o sistema MRT, e a CESP já tinha uma diretriz para projeto em MRT testada e aprovada, as concessionárias decidiram negar toda a padronização da norma proposta pelo autor $e$ padronizar, exclusivamente, como Instrução Técnica para projetos em sistema MRT, a DE/001/TC da CESP. (...)

Apesar dos padrões de estruturas serem os mesmos da norma que havia sido proposta, ela não atenderia as condições plenas necessárias para assegurar a opção pelo seu uso. Em um ambiente tenso, as concessionárias aceitaram acrescentar partes do texto da norma que anteriormente havia sido proposta. Consolidou-se que, a DE/001/TC seria precedida de orientações à escolha do tipo de sistema de extensão de rede, sempre privilegiando o sistema MRT (conteúdo que havia sido apresentado na proposta), passando a ser intitulada 'Instrução Técnica Unificada N $N^{\text {. }}$ 01' (ITU-01).” (JUCÁ, 1998, p. 119-121)

Segundo JUCÁ (1998), a aprovação da ITU-01 significou, para a engenharia de distribuição das concessionárias, a conclusão de sua tarefa. Nunca mais se discutiu os aspectos técnicos ou quis se rever alguns critérios. Há também a tendência de se ignorar alguns avanços contidos na norma. Quando não convêm à concessionária, ao engenheiro, ou ao projetista a utilização de determinado critério ou dispositivo mais barato contemplado na ITU-01, simplesmente ele é ignorado. É sabido que poderia haver apenas questionamentos, nada mais. Nenhuma medida cautelar existe na ITU-01 ou proposição de estudos para melhorias nos padrões técnicos. 
Paralelo ao processo de elaboração da norma técnica, discutiu-se a adoção de um sistema único de apropriação de custos para fazer os orçamentos de referência dos projetos. Assim, cada projeto de rede teria custos de material e mão-de-obra orçados numa mesma base, independente de qual concessionária fizesse o projeto. As discussões desenvolveram-se de forma mais tranqüila, optando-se por estabelecer os valores dos itens mais significativos na composição de custos, como transformadores, postes, condutores, isoladores, pára-raios, e itens de mão-de-obra. Os valores adotados aproximam-se das médias do mercado e são geralmente menores que os praticados pelas concessionárias. Apesar do sistema não estar sendo continuamente atualizado, refletindo o comportamento real do mercado, constitui-se num avanço importante, pois os valores apresentados pelas empreiteiras não podem ficar acima dos valores de referência, aumentando os custos para a comunidade.

Em março de 1997 foi realizado um Seminário Técnico com o pessoal de campo, visando consolidar as informações sobre o programa e motivar a sua implantação. Foram apresentadas também a ITU-01 e a nova lei do FEAP.

Até aquele momento, não se imaginava que a lei aprovada fosse excludente. Ao contrário, a expectativa era que ela fosse a solução para os problemas que já se avolumavam em campo, pois não se podia assinar nenhum contrato. A situação de exclusão só foi percebida depois, deixando a coordenação do programa sem ação.

A tramitação dessa lei mostra a imensa falta de coordenação política do governo e a falta de atenção da Agricultura ao programa. A minuta de lei preparada por aquela Secretaria foi à apreciação da Secretaria da Fazenda, que vetou o aval aos nãoprodutores rurais, alegando já existir o FEER para esse fim, alternativa descartada no início do planejamento. A Secretaria de Agricultura aceitou o veto, não o comunicou à 
coordenação do programa e nem ponderou à Fazenda o fato de que esta já havia aportado recursos ao FEAP para que este subvencionasse todos os beneficiários do programa.

Instituía-se assim a exclusão. Para os não produtores rurais serem financiados, era preciso agora que arranjassem um avalista de maior renda e proprietário de dois imóveis, algo impraticável a tais pessoas. Como, numa comunidade qualquer, misturamse produtores e não produtores rurais, ficava configurada a impossibilidade de haver um atendimento equânime de todos os moradores rurais.

A capacidade de reação a essa dificuldade foi muito pequena. O problema foi levado ao Secretário de Energia, que determinou que as concessionárias avalizassem estas pessoas. Tal solução foi vetada pelos departamentos jurídicos das empresas e da Nossa Caixa, depois de muita discussão e mais alguns meses de demora, atendendo a uma resolução do Banco Central, que entende que esse aval implica no Estado garantindo um empréstimo do mesmo Estado, o que é proibido. Determinou-se, então, que as concessionárias deveriam procurar soluções próprias.

A Eletropaulo, que desde o início procurou fazer com que o programa fosse implantado como o planejado, praticamente paralisou suas atividades nesse período, de abril a outubro de 1997. Houve grande esforço do coordenador responsável na empresa em encontrar soluções, que vieram com a elevação do patamar de enquadramento do pobre rural de baixa renda, que passou a ser de até três salários mínimos mensais, equiparando-se à política de atendimento do pobre urbano na empresa; e com o financiamento direto pela Eletropaulo, nas mesmas condições do BNDES, dos beneficiários não enquadrados na categoria de produtor rural, através de recursos de seu 
próprio orçamento. É uma solução que preserva o "Luz da Terra" na empresa e não modifica em nada as linhas filosóficas do programa.

Outro fato político significativo foi a troca da coordenação do programa "Luz da Terra" na Eletropaulo. O primeiro coordenador, ex-diretor de Distribuição, responsável pelos programas anteriores de eletrificação rural na empresa e de reconhecida atuação na organização de comunidades carentes, foi um dos idealizadores mais atuantes do programa, sendo também referência para o BNDES. A sua intervenção foi importante para vencer resistências na área de engenharia da Eletropaulo, principalmente na redução de exigências para o fornecimento de materiais, que provocavam a duplicação do preço de um transformador, e na possibilidade de contratação de pequenas empreiteiras. Apesar disso, sua força política não era grande e, algum tempo depois de uma mudança na Diretoria de Distribuição da empresa, ele foi defenestrado, não sem antes viabilizar a proposta de financiamento aos não-produtores. O coordenador do programa na Secretaria de Energia chegou a pedir sua permanência, alegando que haveria grande prejuízo para o "Luz da Terra", mas não foi atendido. O substituto, que não era da área mas tinha maior respaldo da direção, atendeu à convocação do Secretário e retomou as atividades interrompidas, na mesma linha de trabalho.

A CPFL retardou ao máximo sua adesão ao programa, assinando o contrato com a Nossa Caixa apenas em julho de 1997. Em todos os momentos do programa em que precisou-se de uma resposta formal, a CPFL sempre foi a última a responder. Com a questão do aval não seria diferente. Apesar dos pareceres jurídicos contrários, a empresa insistiu nessa possibilidade, aprovando resoluções que remetiam sempre à chancelas de instâncias superiores. Quando finalmente o assunto chegou à instância maior, o Conselho de Administração, em outubro de 1997, a empresa já estava privatizada e o 
novo dono concordou em avalizar os não-produtores, convencido pela Secretaria de Energia, com o argumento de que esses empréstimos têm um histórico de baixa inadimplência. Pode-se dizer que foi uma feliz coincidência.

A CESP desde o início do programa vinha procurando caminhos alternativos aos inicialmente traçados. Detentora de grande experiência de campo e programas rurais em andamento, sempre da maneira tradicional, contratando grandes empreiteiras, procurava moldar o modelo proposto às suas experiências, sem grande sucesso. Ao pedido de solução do problema do aval reagiu logo, apresentando não apenas uma proposta, mas um programa inteiro, com começo, meio e fim. E, mostrando sua discordância do modelo, apresentou-o à coordenação do "Luz da Terra" já devidamente aprovado pelo Secretário de Energia, sem intermediários, “poupando” a coordenação de perder tempo em sua análise.

Este "programa paralelo", como ficou conhecido, apresenta diferenças marcantes em relação à política proposta. Os principais pontos de divergência estão mostrados na tabela 3 . 
Tabela 3

Análise Comparativa entre as Condições do Programa "Luz da Terra" e o desenvolvido pela CESP

\begin{tabular}{|c|c|c|}
\hline Item & Programa "Luz da Terra" & Programa CESP \\
\hline $\begin{array}{l}\text { Forma de contratação } \\
\text { da obra }\end{array}$ & $\begin{array}{c}\text { Diretamente pela } \\
\text { comunidade, com a ajuda } \\
\text { das Prefeituras, podendo } \\
\text { haver mutirão }\end{array}$ & $\begin{array}{l}\text { Empreiteira contratada pela } \\
\text { CESP }\end{array}$ \\
\hline $\begin{array}{l}\text { Participação Financeira } \\
\text { do Consumidor }\end{array}$ & $\begin{array}{l}\text { Rateio do custo total do } \\
\text { projeto pelos } \\
\text { interessados }\end{array}$ & $\begin{array}{l}\text { Participação de acordo com a } \\
\text { tabela 4, independente do custo } \\
\text { do projeto }\end{array}$ \\
\hline Subsídios & $\begin{array}{l}\text { Ligação gratuita para as } \\
\text { famílias de baixa renda }\end{array}$ & $\begin{array}{l}\text { Todos participam de acordo com } \\
\text { a tabela } 4 \text {, inclusive baixa renda }\end{array}$ \\
\hline Carência & de 6 meses a 1 ano & $\begin{array}{c}\text { não há ( } 1^{\text {a }} \text { parcela paga no ato da } \\
\text { assinatura do contrato) }\end{array}$ \\
\hline Número de Prestações & $\begin{array}{l}72 \text { parcelas mensais } \\
\text { (6 anos) }\end{array}$ & $\begin{array}{l}\text { até } 36 \text { parcelas mensais } \\
\text { (3 anos) }\end{array}$ \\
\hline $\begin{array}{l}\text { Juros e Correção } \\
\text { Monetária }\end{array}$ & $\begin{array}{l}\mathrm{TJLP}^{1}+3,5 \% \\
\text { anuais }\end{array}$ & $\begin{array}{l}\text { IGP-M }{ }^{2}+12 \% \\
\text { anuais }\end{array}$ \\
\hline \multirow[t]{3}{*}{ Garantias } & $\begin{array}{l}\text { a) equivalência em } \\
\text { produto (para o caso } \\
\text { da inflação subir mais } \\
\text { do que os preços dos } \\
\text { produtos agrícolas). }\end{array}$ & $\begin{array}{l}\text { a) não têm equivalência em } \\
\text { produto. }\end{array}$ \\
\hline & $\begin{array}{l}\text { b) refinanciamento pelo } \\
\text { FEAP no caso de } \\
\text { quebra de safra. }\end{array}$ & b) não têm refinanciamento. \\
\hline & $\begin{array}{l}\text { c) extensionismo rural } \\
\text { por parte das Casas da } \\
\text { Agricultura. }\end{array}$ & $\begin{array}{l}\text { c) não têm integração com as } \\
\text { Casas da Agricultura. }\end{array}$ \\
\hline
\end{tabular}

\footnotetext{
${ }^{1}$ Taxa de Juros de Longo Prazo. Em dezembro de 1997 era de 9,89 \% anuais.

2 Índice Geral de Preços do Mercado. No ano de 1997, foi de 7,74\%.
} 
Tabela 4

Planilha de participação financeira de consumidores para o programa de eletrificação rural CESP

\begin{tabular}{cccc}
\hline $\begin{array}{c}\text { Renda familiar } \\
\text { mensal }\end{array}$ & \multicolumn{3}{c}{ Custo em função da distância da rede } \\
\hline 0 a 3 SM $^{3}$ & $\mathrm{R} \$ 700,00$ & $\mathrm{R} \$ 800,00$ & $\mathrm{R} \$ 900,00$ \\
\hline 3 a 6 SM & $\mathrm{R} \$ 1.300,00$ & $\mathrm{R} \$ 1.400,00$ & $\mathrm{R} \$ 1.500,00$ \\
\hline Acima de 6 SM & $\mathrm{R} \$ 1.900,00$ & $\mathrm{R} \$ 2.000,00$ & $\mathrm{R} \$ 2.100,00$ \\
\hline Fonte: CESP & & &
\end{tabular}

Neste programa o banco é dispensado, a Agricultura é dispensada, a prefeitura não atua junto, a Universidade não participa. Um dos objetivos é “contornar a situação atual existente de grande conflito com os técnicos do (sic) SAA e NCNB”, segundo relatório justificativo apresentado à CERESP. A CESP renuncia a seus parceiros, que, afinal, “só atrapalham”, para que o processo seja mais rápido e se cumpra suas metas.

Nota-se que a CESP possui uma dívida imensa, maior responsável pelo débito do estado com o Banespa, que provocou a sua federalização, e mesmo assim dispensa recursos externos para utilizar os seus próprios num programa de pouco retorno econômico. É fato a se observar também que esses recursos não existiam no início de 1995 e tenham surgido às vésperas de um ano eleitoral. Para manter seu programa, a CESP argumenta que está utilizando os recursos de que dispunha para o programa "Luz da Terra" na construção de linhas-tronco e ligação de famílias de baixa renda, que representa cerca de um terço de seu público. Na verdade, paira um mistério em torno da real quantidade de ligações que podem ser feitas com esses recursos. É sabido que não são suficientes para atender toda a demanda existente. Não se sabe também os critérios utilizados para se definir quais pessoas serão atendidas ou não.

A tendência é ligar os mais próximos da rede, que têm custos menores, rapidamente, colhendo os dividendos políticos e empurrando o problema das outras 
ligações para a frente.

Um ponto a ser observado é que a CESP não honrou o compromisso, assumido pelo governo do estado, de ligar gratuitamente as famílias de baixa renda. Até hoje ela não encontrou meios operacionais de ligar um caso desses situado no meio de outros de renda mais alta. No "programa paralelo”, contrariando a política traçada, as famílias mais pobres também pagam.

O “programa paralelo” da CESP fechou 1997 com 3.325 contratos assinados, quase três vezes o realizado pela CERESP. No campo ele é vendido como "Luz da Terra", e sua comercialização é mais rápida, pois não envolve a elaboração do cadastro e do plano de crédito, necessários para a operação bancária. Também observa-se que o programa "Luz da Terra", tal como foi concebido, foi abandonado, em detrimento do “programa paralelo”, onde a CESP passou a concentrar seus esforços, aproveitando o trabalho realizado naquele.

A CESP demonstrou hostilidade em relação à política planejada pelo Secretário de Energia e sempre deu mostras que preferia manter com as empreiteiras as relações que estava acostumada a manter. O programa do BNDES não lhe permitia privilegiar as empreiteiras.

A mecânica do programa que a Diretoria de Distribuição da CESP conseguiu impor é bem no estilo tradicional: conforme declarado por um grupo de empreiteiros, em reunião na Assembléia Legislativa, com a participação da Universidade de São Paulo e da Secretaria de Agricultura: a empreiteira grande contrata por algo como 22,

\footnotetext{
${ }^{3}$ SM: Sálario Mínimo. Em 1997, R\$ 120,00.
} 
passa para outra que ganha 18, que passa para a pequena empreiteira local que ganha o justo.

A Secretaria de Energia, que com o programa "Luz da Terra" se predispôs a mudar essa realidade, acabou atropelada pela conjuntura de um ano eleitoral. A saída encontrada pela CESP foi a negação da política traçada pelo governo do estado. Uma saída que foi amparada por esse mesmo governo, sinalizando a mudança de atitude em relação ao programa. O interesse por resultados rápidos e fáceis falou mais alto que a proposta inicial, mais ampla. 


\section{CAPÍTULO 4 - O PROGRAMA "LUZ DA TERRA" VAI A CAMPO}

O governo paulista assumiu o compromisso político de levar energia elétrica à totalidade das propriedades rurais do estado de São Paulo, através do programa "Luz da Terra". A partir da premissa de que um programa de eletrificação rural bem sucedido não deve apenas visar o simples fornecimento de energia elétrica, mas sim o desenvolvimento integral da zona rural, agregaram-se ao programa outros objetivos como: melhoria da qualidade de vida do homem do campo, desenvolvimento da produção rural via trabalhos de extensão, elevação do nível de organização das comunidades, integração dos órgãos públicos e discussão da problemática energética rural. A eletrificação rural foi vista como um instrumento de desenvolvimento rural.

Para tanto, a política proposta rompe com a prática tradicionalmente utilizada nos programas de eletrificação rural. Se antes os modelos eram centrados na concessionária, o modelo proposto inverte essa relação, descentralizando e solicitando a participação da comunidade em todas as etapas do processo. A comunidade rural, ou o grupo de interessados, é quem deve se mobilizar, cadastrar-se, acompanhar o projeto, obter orçamentos, conseguir o financiamento e ajudar na construção das redes. A concessionária fica com o papel de projetar as redes, elaborar um orçamento de referência, orientar a comunidade na contratação de mão-de-obra, incentivar a organização de mutirões e fiscalizar a rede pronta. A decisão sobre quem vai executar a obra e sobre o orçamento final fica nas mãos da comunidade.

Se o centro de decisão muda, mudam também as relações de poder. A concessionária antes definia quem ia ser atendido, quem ia construir e por quanto. Agora é a comunidade que vai tomar essas decisões, além de ser obrigatório que outros órgãos acompanhem o processo. A liberdade de ação das empresas é restringida e o seu 
controle sobre o processo se esvai. Essa mudança de foco de poder não é feita facilmente. Algumas experiências, como a do Paraná em 83/84 e do Rio Grande do Sul em 90/92 mostram que essa mudança, onde aconteceu, foi feita sempre através de ações políticas, na maioria dos casos encontrando grande resistência. No programa "Luz da Terra" não seria diferente. Era necessário tomar decisões políticas que levassem à efetiva implantação da política proposta. Essas decisões não foram tomadas. No decorrer do processo as concessionárias aplicaram e moldaram o modelo do programa "Luz da Terra" às suas próprias conveniências, às vezes retirando da comunidade as suas funções, às vezes fazendo com que o exercício delas fosse dificultado. Nem sempre isso foi feito com más intenções; algumas vezes aconteceu naturalmente. As ações de campo foram levadas de uma forma tal que o modelo foi descaracterizado, produzindo resultados bastante desanimadores e levando esse mesmo modelo a ser questionado.

\subsection{As ações de campo - fluxo teórico}

As ações de campo do programa "Luz da Terra" foram planejadas antes de seu lançamento, e consolidadas sob a forma de um fluxograma de ações estipulando 36 passos e o papel de cada ator nesses passos. Este fluxograma foi fruto de um trabalho envolvendo todos os órgãos participantes, e teoricamente deveria ser cumprido por todos eles, apesar de possuir caráter indicativo. Para efeito de análise, podemos resumilo em oito ações principais:

\section{a) Articulação local}


Esta etapa contempla a escolha dos municípios onde será implantado o programa “Luz da Terra” e o planejamento operacional das atividades a serem realizadas. Para isso, o primeiro passo é a realização de uma reunião preparatória, marcada por iniciativa da concessionária, da prefeitura, da Secretaria da Agricultura ou de outro órgão interessado, onde devem estar presentes as personalidades e autoridades locais, como o prefeito, a Câmara Municipal, a Nossa Caixa, a Casa da Agricultura, os sindicatos rurais, clubes de serviço, igrejas, associações, cooperativas, órgãos de comunicação, lideranças locais e outras pessoas que se julgar necessárias. Nessa reunião a CERESP, através de um representante, deve expor o programa detalhadamente, identificar as possibilidades de colaboração, definir os papéis e atividades dos participantes, bem como definir a constituição de uma Comissão Municipal de Apoio ao Programa "Luz da Terra". Neste ponto é fundamental destacar a importância da participação da comunidade, inclusive quanto ao aspecto dos trabalhos em mutirão. Nesta reunião também deve ser estabelecido um cronograma de trabalho para o município, com o início dos trabalhos de divulgação e uma data inicial para o lançamento oficial do programa.

O resultado do trabalho de articulação local é uma comissão municipal formalizada, onde cada órgão tem sua responsabilidade claramente definida, e um plano de ação para a implantação do programa no município, inclusive com a verificação de todos os recursos locais que podem ser utilizados para diminuir os custos de implantação das redes, como: utilização de recursos materiais e humanos das Prefeituras Municipais, possibilidade da prefeitura ou outra entidade de gerenciar as compras para a comunidade, formação de equipes de apoio para os mutirões, confecção de material de 
divulgação, resolução de possíveis problemas com permissão de passagem da rede elétrica, viabilização de eventos para arrecadação de dinheiro, etc.

\section{b) Cadastramento}

O cadastramento dos interessados no programa deve ser induzido pela realização de um processo de ampla divulgação através da mídia e outros espaços, em conformidade com um projeto global de comunicação desenvolvido pelos participantes da comissão municipal. Todos os meios possíveis para divulgação devem ser utilizados: faixas, cartazes, folhetos, cartilhas, jornais, rádios, canais de TV, unidades móveis, concursos escolares, etc. Além disso, podem-se realizar ações mais específicas, como idas a campo, visitas a escolas e bairros rurais, com a finalidade de identificar todos os clientes potenciais do programa. Neste momento, a participação da prefeitura é fundamental, pois é ela que detém o conhecimento da sua região e sabe onde estão os moradores da área rural que ainda não possuem energia elétrica.

Com as ações de propaganda se desenvolvendo, os interessados preenchem uma ficha encontrada dentro dos folhetos de divulgação do Programa e entregam às agências da Nossa Caixa, escritórios das Concessionárias, Casas da Agricultura, Prefeituras Municipais, etc., demonstrando seu interesse em receber o benefício. Tais fichas, que também podem ser apresentadas através de listas desenvolvidas por qualquer agente da sociedade (prefeituras, sociedades amigos de bairro, cooperativas, etc.), têm como destino final a concessionária responsável pela região, que elabora, em uma segunda etapa, cadastro técnico contendo os dados necessários à implementação dos estudos referentes a estas novas ligações. Este cadastro é completado pela área técnica da respectiva concessionária com possíveis consumidores ainda não cadastrados, a partir da visita de campo. 
Nesse ínterim, devem ser providenciados os documentos necessários à obtenção do financiamento. Os interessados, caso não possuam documentos como carteira de identidade (RG) e inscrição no Cadastro de Pessoa Física (CPF) da receita federal, devem providenciá-los, com a ajuda da comissão municipal.

\section{c) Triagem, projeto e plano de crédito}

Um programa de eletrificação rural que envolva operações de crédito individuais a cada interessado necessita que se façam duas operações, distintas e concomitantes: um projeto elétrico e um projeto de crédito. É preciso que se atendam os requisitos técnicos da empresa de energia elétrica e do banco. Os dois processos têm que caminhar em paralelo, para que no final sejam obtidos os resultados esperados: um projeto que contemple todos os interessados e tenha baixo custo e a definição exata das formas de pagamento e tomada de empréstimos dos beneficiários, eliminando as restrições bancárias. Por essa razão, após a etapa de cadastramento, o programa "Luz da Terra" prevê que se inicie a triagem bancária preliminar e a elaboração de um projeto técnico preliminar.

Triagem: esta etapa procura identificar os possíveis impedimentos de alguns interessados em obter o financiamento tais como emissão de cheques sem fundo, nome inscrito nos serviços de proteção ao crédito, inadimplência em algum financiamento ou dívida, etc., a fim de não interromper o processo nas etapas finais. Se foi realizada a triagem preliminar e constatado algum impedimento, a Nossa Caixa deve informar o fato rapidamente à comissão municipal ou à comunidade para as providências devidas. A elaboração do plano de crédito simplificado, onde constam dados da renda do beneficiário, e que é documento obrigatório para o financiamento, já deve ser iniciado pela Casa da Agricultura. 
Projeto: tendo por objetivo o atendimento de todos os clientes, a concessionária elabora o projeto técnico da rede, agregando os interessados por bairros rurais ou da maneira mais conveniente para o planejamento econômico do sistema elétrico, aplicando a ITU-01. Os projetos devem seguir sempre a filosofia de menor custo, sendo adequados às reais necessidades de carga do consumidor rural e adotando, onde possível, o sistema MRT, a utilização de traçados de rede otimizados e o uso de materiais como condutor de aço zincado (CAZ), postes de madeira e transformadores de pequeno porte. Este projeto é orçado através do sistema de custos unificado, e este orçamento de referência deve ser fornecido em sigilo para a Nossa Caixa, para evitar sua divulgação às empreiteiras, que podem oferecer orçamentos menores.

\section{d) Adesão da comunidade}

Uma vez elaborado o projeto técnico, são feitas reuniões com a participação da concessionária, da Nossa Caixa, dos responsáveis pela extensão rural (Casas da Agricultura), dos beneficiários finais, da Prefeitura Municipal e de representantes da sociedade, quando procura-se determinar a adesão ao programa. Nessa reunião deve-se:

- explicar detalhadamente o programa, indicando a função e responsabilidade de cada agente, inclusive da comunidade;

- expor os usos e vantagens da eletricidade;

- explicar os detalhes dos custos, do financiamento, da importância da adesão de todos, do sistema de equivalência em produto, da possibilidade do uso de mutirão e quaisquer outras dúvidas que surgirem; 
- buscar e convencer os ausentes, através de ações da comunidade e da prefeitura. Deve-se evitar ao máximo a ocorrência de “bocas-de-espera”, que são aquelas pessoas que esperam a rede ficar pronta para pedir a ligação, a um custo mais baixo;

- resolver problemas com permissão de passagem da rede a ser construída;

- identificar lideranças e organizar uma comissão de representantes da comunidade, para a realização das ações subsequentes.

\section{e) Orcamento da comunidade}

Nesta etapa há o repasse do projeto à comunidade ou ao grupo de interessados que, através da comissão de representantes, providencia o seu orçamento, usualmente através da contratação de serviços, materiais e mão-de-obra de uma empreiteira de sua escolha. Esta ação de busca por orçamentos deve ser orientada e apoiada por todos os envolvidos, particularmente a prefeitura (que pode disponibilizar recursos como telefone e fax) e a concessionária, mas as ações devem partir da comunidade. É aberta também a possibilidade de a comunidade entrar em acordo com as empreiteiras e realizar tarefas não especializadas em regime de mutirão, de modo a reduzir o custo da ligação. A comunidade pode também efetuar a compra dos materiais, por iniciativa própria ou assessorada por empreiteiras ou pela prefeitura. Além destas, todas as possibilidades para a redução de custos devem ser utilizadas, como negociação direta com os empreiteiros, apoio material de outras entidades, doações, realização de rifas, bingos, festas e rodeios, etc. É papel dos agentes incentivar as comunidades a buscar todas as formas possíveis para barateamento das ligações. O orçamento deve ser detalhado por itens de mão-de-obra e material, segundo padrões definidos. 
Escolhido o orçamento mais adequado (de valor próximo ao orçamento de referência), é feito o cálculo da parcela a ser paga por cada beneficiário. De posse desse valor, ele poderá decidir se irá optar pelo financiamento de todo ou parte do valor ou pelo pagamento direto à empreiteira e fornecedores, à vista ou à prazo, conforme negociação.

Nesta etapa também ocorre a conclusão dos trabalhos relativos à elaboração do plano de crédito simplificado do beneficiário potencial para enquadramento nos financiamentos, o estabelecimento dos critérios para a adoção da equivalência em produto e a definição dos interessados de baixa renda.

\section{f) Análise do processo}

Este item prevê o envio do processo à CERESP pela concessionária. Lá, ele é submetido à apreciação da COMTEC, onde há a participação das concessionárias e da Universidade de São Paulo, verificando o atendimento à instrução técnica unificada e ao sistema de custos unificado. É verificado também se existem todos os documentos necessários para a concessão de crédito, como a ficha cadastral de cada beneficiário, o plano de crédito simplificado assinado pelo responsável da Agricultura, os números do CPF e RG de cada interessado e a descrição da situação de enquadramento (financiável, baixa renda ou recursos próprios). Se o processo for rejeitado pela Comissão Técnica, volta à concessionária e/ou ao município para as correções necessárias. Se aprovado, é emitido um parecer formal e o processo é enviado ao Departamento Rural da Nossa Caixa, que faz um exame detalhado dos quesitos necessários e possibilidades de financiamento.

\section{g) Contratação do financiamento}


Após a aprovação dos financiamentos aos beneficiários pela Nossa Caixa, esta emite os contratos de financiamento individuais e os remete às suas agências locais. Estas providenciam então a notificação dos beneficiários para comparecer à agência ou a outro local, estabelecido em conjunto com a comissão municipal, para a assinatura dos contratos. Nessa ocasião também procede-se à assinatura do contrato com a empreiteira para início das obras, do termo de adesão ao FEAP e do termo de doação das linhas, além de começar a contar o prazo de carência. Após a assinatura de todos os contratos, a Nossa Caixa remete o pedido de liberação da verba do projeto para o BNDES, que é depositada numa conta em nome dos beneficiários, indisponível para outros fins.

\section{h) Execução das obras.}

Assinado o contrato de financiamento, definida a origem dos recursos a serem utilizados e depositado o dinheiro no banco, inicia-se a compra de materiais e a construção das redes, pela empreiteira ou pela comunidade, que pode, com a ajuda de associações, cooperativas, prefeitura, etc., responder pela execução de parte das tarefas de construção através do fornecimento de mão-de-obra não-especializada para várias atividades. A concessionária deve acompanhar a obra, verificando se os materiais adquiridos e a mão-de-obra especializada e não-especializada contratadas estão de acordo com as especificações previamente estabelecidas para a obra, exercendo a fiscalização qualitativa e quantitativa dela e atestando a exatidão das informações para ser efetivado o pagamento dos fornecedores pela Nossa Caixa, até o limite de $80 \%$ do valor financiado. Cabe ainda à concessionária a ligação da rede e dos novos consumidores, após ser realizada a vistoria final da obra, autorizando o banco a efetuar o pagamento da parcela final de $20 \%$. As parcelas do financiamento, que começam a ser pagas após vencido o período de carência, serão arrecadadas pelas concessionárias 
nas contas de luz de cada beneficiário e repassadas à Nossa Caixa. Em caso de inadimplência, o banco pode pedir à concessionária o desligamento do consumidor, a título de preparação para a remoção das instalações.

\subsection{A prática do programa "Luz da Terra"}

Durante a primeira fase do programa "Luz da Terra", que é objeto de análise deste trabalho, verificou-se que a sua implementação foi realizada de forma bastante inconsistente: os passos previstos e expressos no fluxograma descrito ou eram feitos na ordem incorreta, ou eram reinterpretados ou simplesmente não eram realizados. Além disso, de empresa para empresa, ou mesmo de regional para regional, o entendimento e a realização desses passos foi diversa, fragmentando a ação política desejada. O que será feito a seguir é uma análise da atuação de cada ator envolvido no processo e sua relação com o modelo proposto de implantação, a partir do acompanhamento das ações de campo.

\subsubsection{A Eletropaulo}

A Eletropaulo é uma empresa de distribuição de energia elétrica de perfil essencialmente urbano. Apenas 0,23\% dos seus consumidores e 0,51 \% da energia consumida em sua área de concessão vem da área rural (CESP, 1996). Com relação à eletrificação rural, praticava, até 1994, um dos custos mais elevados de extensão de redes rurais, tanto para sistemas monofásicos como para trifásicos. Neste ano, um trabalho de racionalização provocou uma redução de 60 \% nesses custos, em média (CEER, 1995), através do uso de materiais recuperados da rede urbana, sistemas monofásicos, revisão de projetos, traçados de linhas e cálculos mecânicos e contratação de pequenas empreiteiras por carta-convite, num programa denominado PER (Programa 
de Eletrificação Rural). Este programa não obteve sucesso, efetuando apenas 84 ligações num total de 5.739 cadastrados até janeiro de 1995. Um de seus resultados foi o cadastramento realizado em algumas regiões e a elaboração de uma nova norma para a área rural, contemplando o sistema monofásico com retorno por fio, o uso de postes de madeira e a otimização no espaçamento dos vãos.

A implantação do programa "Luz da Terra" na Eletropaulo iniciou-se com um trabalho de divulgação interna junto aos seus agentes, através da realização de seminários expondo o programa em dois núcleos regionais de distribuição (Vale do Paraíba e Leste), em julho de 1996. Estes seminários visavam divulgar as diretrizes básicas do programa que seria lançado em dois meses, além de preparar sua implantação; outro objetivo era esclarecer os técnicos sobre as possibilidades da nova norma (ainda não era a ITU-01). Cabe dizer que os técnicos encarregados de projetar as redes rurais são os mesmos da área urbana, ou seja, carregam consigo os parâmetros dessa situação, sendo necessária uma reciclagem de seus conhecimentos a fim de adaptá-los a uma nova realidade.

Quanto à implantação em campo, a Eletropaulo é a concessionária que mais procura seguir o fluxograma de ações. Além de ter realizado o projeto piloto do programa no município de Pindamonhangaba, tem procurado envolver os outros órgãos participantes (Universidade de São Paulo, Nossa Caixa, Prefeituras Municipais, Casas da Agricultura), mas não tem sido bem sucedida.

A abordagem do programa "Luz da Terra" na Eletropaulo inicia-se através de uma reunião em cada Prefeitura Municipal, na qual são expostos os procedimentos do programa e suas condições ao prefeito e aos agentes locais. Finda essa reunião, é feita uma tentativa de formar uma comissão municipal. Uma segunda reunião é marcada, 
geralmente para planejar as ações de divulgação. Após isso, é marcada uma data para a cerimônia de lançamento oficial. Nesse ínterim, as equipes de projeto vão a campo para elaborar os primeiros projetos técnicos, cadastrando e fazendo contatos com as pessoas. Algumas prefeituras também têm ajudado nesse cadastramento. O ponto de partida da Eletropaulo é sempre o cadastro anterior do antigo PER.

Após o lançamento, que tem se caracterizado como um evento político importante, com a presença de autoridades locais e da empresa, a articulação local esmorece. Em grande parte dos casos é porque os agentes locais não conseguem se entrosar. Não há entendimento entre a Agricultura, a Nossa Caixa, a Eletropaulo e as prefeituras, nem a coordenação é assumida por um desses órgãos. Não há também ninguém que cobre os resultados no município, levando o programa a um certo abandono.

Uma restrição verificada é a pequena capacidade da companhia em fazer os projetos técnicos. Os técnicos não estão disponíveis o tempo todo para o programa. A regional Leste chegou a parar por alguns meses os projetos. Outro ponto importante é a resistência da empresa em utilizar o sistema MRT. Apesar de haver assinado a instrução técnica unificada do programa, não a aplica. Até dezembro de 1997 não havia sido realizado nenhum projeto em MRT. As restrições colocadas pelo seu departamento de engenharia são de que ele é um sistema perigoso e de manutenção cara. Mesmo o pessoal de campo não é muito favorável à sua utilização, em parte por "falta de cultura interna”, que pode ser traduzida mais ou menos como ignorância, em parte por trazer ainda a cultura do projeto urbano.

Esta recusa também nunca é admitida abertamente. Fala-se às vezes que o MRT é uma alternativa, mas essa alternativa nunca é usada. 
Na etapa de orçamentos da comunidade, o projeto técnico é entregue diretamente a ela, que deveria providenciar seu orçamento. A comunidade, por conta de restrições naturais de recursos, organização e escolaridade, tem grande dificuldade de fazer isso. Há casos de comunidades que receberam o projeto e ficaram esperando que as empreiteiras a procurassem. Outras demoraram meses para conseguir o orçamento, e outras ainda desistiram, pelas dificuldades encontradas. O apoio a elas, que deveria ser dado pela concessionária ou pela comissão municipal, não ocorreu, salvo raras exceções. O modo de obter orçamentos era sempre o mesmo, através de empreiteiras que forneciam material e mão-de-obra. Não há casos de mutirão.

As empreiteiras acabaram tendo seu papel ampliado, às vezes desvirtuando o programa. Em Araçoiaba da Serra, região de Sorocaba, ocorreu um caso extremo.

A regional Oeste da Eletropaulo terceirizou a elaboração de projetos técnicos, contratando uma empreiteira da região para fazer essa tarefa. Esta empreiteira também atua construindo redes. Sabendo quais comunidades possuíam projetos, ia até lá e oferecia um plano próprio de financiamento, em quatro ou cinco parcelas, com cheque pré-datado, para construir a rede. O argumento que usava para convencer as pessoas foi que o financiamento da Nossa Caixa era muito complicado, e elas não conseguiriam acessá-lo. Outras vezes, a comunidade nem era informada que existia o financiamento do banco, apenas o plano direto com o empreiteiro. Isso gerou grande revolta em algumas pessoas, que não tinham condições de pagar uma prestação que chegava a R\$ 300,00. As reclamações chegaram à prefeitura, que havia ajudado no cadastramento e não foi convocada a nenhuma outra ação. Querendo esclarecimentos, acionou a Universidade de São Paulo e a CERESP, dizendo que a Eletropaulo não fornecia os projetos à prefeitura. Houve, então, uma reunião com a Eletropaulo, a prefeitura, a 
Universidade e representantes da CERESP onde esclareceu-se a situação e orientou-se a prefeitura quanto aos procedimentos do programa, com ela assumindo o compromisso de apoiar as comunidades.

Um outro ponto que atrasou bastante os trabalhos foi a indefinição quanto ao enquadramento dos moradores rurais não produtores, casos que constituem a maioria dos possíveis beneficiários da área da Eletropaulo. Esta indefinição paralisou o programa por vários meses, inclusive em municípios onde havia projetos já com orçamento, inibindo o desenvolvimento do programa em outras comunidades e em toda a empresa, que “esperavam para ver”. Isto também deixou algumas comunidades revoltadas pois não tinham seu financiamento liberado, gerando grande prejuízo à imagem do programa. Particularmente em Pindamonhangaba, onde a Eletropaulo realizou um projeto-piloto, logo após o lançamento do programa, as indefinições tiveram bastante influência: “Oito meses passando por palhaços” (frase de um interessado).

Efetivamente, a prática da Eletropaulo mostrou que existia um hiato entre a coordenação do programa na empresa e seus agentes regionais. A política é apresentada às prefeituras, que se comprometem, mas não há um seguimento, nem da parte dos núcleos regionais, nem da CERESP. Viu-se que havia outras prioridades para a empresa, e que a eletrificação rural não tinha o destaque desejado. A atitude dos agentes locais foi muito passiva. Esta experiência da Eletropaulo mostra o quanto o apoio de uma equipe independente era necessário. 


\subsubsection{A CESP}

Ao contrário da Eletropaulo, a CESP é uma empresa voltada muito mais para a geração e transmissão de energia elétrica do que para a distribuição. A história da formação da CESP (em 1966, a partir da fusão de várias empresas estaduais) mostra que a empresa foi utilizada como instrumento estatal para eletrificar regiões onde não havia grande interesse da iniciativa privada em atuar. Não por acaso, eram, e ainda são, as regiões mais pobres do estado de São Paulo, como o Vale do Ribeira e o Sudoeste do estado (região de Itapeva). Ou então eram regiões de fronteira, onde começava a haver ocupação mais intensa (Noroeste do estado e Pontal do Paranapanema). Nessas regiões, a atuação da CESP sempre foi um vetor de desenvolvimento, até pela deficiência de estrutura de outros órgãos governamentais. Não é incorreto dizer que a CESP, por causa disso, teve e tem grande influência política nessas regiões, pois era a “mão” do governo estadual nessas áreas.

Por conta disso, a eletrificação rural sempre foi uma constante na companhia e teve um papel relativamente mais importante que nas outras concessionárias estaduais. Em 1996, 6,11 \% dos seus consumidores e 6,22 \% da energia consumida em sua área de concessão vinham da área rural (CESP, 1996). Entre 1980 e 1994 foram eletrificadas 47.600 propriedades rurais (CEER, 1995). No começo de 1995, quando tiveram início as discussões do programa “Tem Luz?”, a CESP propunha quatro programas rurais, com a meta de eletrificar 3.014 clientes rurais no ano (CEER, 1995). A pobreza e o baixo desenvolvimento econômico da sua área de concessão mostram que ainda há um grande esforço a ser feito. No fim de 1997 havia mais de 22 mil propriedades cadastradas, das quais cerca de 30 \% com renda familiar abaixo de um salário mínimo, segundo dados da própria empresa. Os programas desenvolvidos sempre foram da 
forma tradicional: a CESP identificava o potencial e contratava grandes empreiteiras para realizar as obras. Estas, por sua vez, subcontratavam pequenas empreiteiras locais. Nesse esquema, os custos acabavam se elevando. A média prevista nos programas propostos pela CESP em 1995 era de US\$ 3.866,00 por ligação (CEER, 1995). Os recursos vinham majoritariamente do governo do estado e da CESP, ficando o beneficiário com a participação de $10 \%$.

Pelas características da região a ser atendida, a redução de custos e a rapidez de andamento dos processos foi uma preocupação da área técnica da CESP. O sistema MRT foi utilizado experimentalmente a partir de 1986 e padronizado em 1990 (JUCÁ, 1998) e a passagem por dentro de terrenos buscando o traçado mais retilíneo é uma prática constante. A limitação do uso do MRT pelas características do sistema de proteção levou ao estudo e adoção de sistemas bifásicos verticais e o uso dos transformadores de isolamento. Apesar de haver questionamentos em relação à escolha e ao uso dos sistemas, não se pode dizer que a CESP não estudou nem procurou alternativas técnicas para um atendimento mais econômico.

Havia então, por ocasião da implantação do programa "Luz da Terra" na CESP, uma cultura de eletrificação rural já estabelecida. Esta cultura se refletia em procedimentos bem conhecidos por suas equipes, em que a concessionária comandava todas as etapas de implantação e em que a participação de outros agentes era pequena. Nesse sentido, a transição para um novo modelo, em que a participação da comunidade e dos outros órgãos é preponderante, tendia a ser problemática se não houvesse uma ação externa à empresa, para garantir a implantação do programa com suas linhas políticas. Na realidade, como não houve essa ação, o que ocorreu foi uma adaptação do modelo do programa "Luz da Terra", ao qual ela tinha resistências e achava ruim, ao 
modelo da empresa. Essa adaptação foi cercada de problemas e, em certa medida, desastrosa, desgastando agentes, comunidades e o próprio programa.

A adaptação carregou os vícios da atuação da CESP em suas áreas. A participação dos outros atores, principalmente as prefeituras, foi deixada de lado, em parte por causa das dificuldades estruturais destas, mas, na maioria das vezes, pela incapacidade e desinteresse da CESP em envolvê-las. Com isso, muitas das tarefas que caberiam a seus parceiros foi realizada pela CESP, sob a alegação de que alguém tinha que realizar as ações. Tarefas como preenchimento do plano de crédito simplificado, preenchimento de ficha cadastral bancária, auxílio na obtenção de documentos, obtenção de orçamentos, negociação com empreiteiras e localização de interessados foram assumidas pela CESP, numa clara demonstração de um modelo "rolo compressor”.

A articulação local não foi feita. A companhia alega que foram visitadas todas as Prefeituras Municipais e solicitado apoio, mas que, após terem manifestado um certo interesse inicial, na prática elas não colaboravam em nada. Na verdade, o modo como foi exposto o programa em cada uma delas mostra que a proposta de colaboração não foi enfatizada. O programa "Luz da Terra" foi exposto como se fosse uma ação isolada da CESP (diferente da Eletropaulo, que desde a primeira reunião deixa claro que o programa é uma ação do governo estadual), cabendo à Prefeitura Municipal tomar conhecimento e ajudar, no máximo, no cadastramento. Assim, a articulação local é muito fraca, como apontam as visitas de campo realizadas pela Universidade de São Paulo ${ }^{4}$ :

\footnotetext{
${ }^{4}$ Os depoimentos e impressões relativos às cidades e regiões do estado de São Paulo presentes nesse trabalho foram colhidos pela equipe de pesquisadores do PEA-EPUSP durante o ano de 1997, dentro do
} 
Moji-Mirim: o prefeito relata: "A CESP avisou sobre o programa sem dar muitas informações e pediu ajuda à prefeitura na divulgação e também no cadastramento das pessoas interessadas. (...) A impressão passada foi que o programa era uma iniciativa da CESP, e (o prefeito) realmente não sabia das demais atribuições da prefeitura nem dos outros órgãos envolvidos nem dos detalhes do projeto quanto a organização e financiamento."

Santo Antônio da Posse: o prefeito ficou surpreso ao saber que o programa era uma iniciativa do governo estadual. " Achei que o programa era da CESP! ”

Região de Itapeva: A maioria das prefeituras não foi procurada pela CESP e ficaram surpresas quando foram informadas que poderiam dar auxílio à população rural.

Conchal: O secretário de planejamento disse: "Este programa fornece a coisa mais difícil para realização de qualquer obra, o dinheiro. Dessa forma o que cabe à prefeitura é simples e relativamente fácil, e acredito que as articulações locais necessárias só não foram feitas até agora por falta de informações mais detalhadas sobre o programa."

Torre de Pedra: foi contatada a Sra. Léia da prefeitura que informou que foram realizados trinta cadastros pela CESP em maio de 1996 e além disso nada mais foi realizado, nem ao menos material publicitário foi enviado para divulgação do programa.

Piracaia: foi contatado o gerente da Nossa Caixa Nosso Banco e ele falou que tem conhecimento do programa (não detalhadamente), mas não se envolveu ainda, porque não foi procurado.

Quando há participação de outros agentes, eles atuam apenas na fase de cadastramento, que é onde houve mais avanço:

Porangaba: na fase de articulação a Casa da Agricultura em cada visita, falava aos produtores a respeito do programa, e serviu como ponto de cadastramento.

Pilar do Sul: a Casa da Agricultura cadastrava e enviava os dados para a CESP.

Mongaguá: a ação da prefeitura aumentou de 150 para cerca de 400 os cadastrados.

A conseqüência é que o trabalho de triagem preliminar, plano de crédito e projeto, que deveria andar de forma paralela e homogênea, apresenta grande descompasso: na região de Registro há cerca de 2.500 clientes com projeto e sem plano 
de crédito; em Ribeirão Branco o agrônomo desconhecia a ficha do plano de crédito; em Pilar do Sul a CESP não havia enviado os cadastros para a triagem preliminar na Nossa Caixa. Em Iguape a triagem era feita após o orçamento e algumas fichas estavam sem documentos, atrasando o processo.

Em pelo menos um lugar, no município de Piedade, havia uma situação de exclusão. O agente local da CESP tinha ordens de cadastrar somente quem estivesse a $200 \mathrm{~m}$ da rede.

A adesão da comunidade é feita através de reuniões, em alguns casos. Mesmo assim, compareciam apenas cerca de $70 \%$ das pessoas daquele projeto, segundo estimativa da própria CESP de Registro. Em outras regiões não havia nem mesmo a reunião. Na região de Itapeva, as comunidades apenas faziam o cadastro e esperavam a ligação.

A etapa de orçamentos foi resolvida com a CESP adotando uma prática diferente da planejada. O motivo alegado para mudar os procedimentos propostos pelo programa foi de que a CESP havia verificado que daquele jeito os processos “não andariam”, e que ela iria "perder o controle do projeto". Essa verificação foi feita entregando-se projetos para algumas comunidades, sem dar apoio ou fazer a articulação local. Assim, passaram a procurar um caminho alternativo, adotando a seguinte prática, exposta num seminário interno da concessionária, em abril de 1997:

- o projeto, após ficar pronto, é encaminhado às empreiteiras cadastradas para a obtenção de orçamentos;

nํㅡㄴ-8000-002-9/96, e relatados à Eletropaulo, CESP e CPFL em relatórios mensais de acompanhamento. 
- paralelamente, é feita a organização de uma reunião com a comunidade, onde todos os participantes do projeto são convocados e devem estar presentes;

- nessa reunião, são abertas as propostas das empreiteiras e a comunidade escolhe a que melhor lhe convier, assessorada pela concessionária. Após uma ter sido escolhida, passa-se à negociação direta entre comunidade e empreiteira de pontos como utilização de mutirão e parcelamento da parcela à vista.

Esta é, na teoria, a prática utilizada. Nas reuniões de abertura de propostas acompanhadas, fala-se que a comunidade pode trabalhar em mutirão, mas não são realizadas ações para levar a isso. A condução das reuniões é feita de forma tal que a comunidade apenas referenda o menor preço oferecido. Uma posterior negociação quanto ao preço é conduzida pela CESP, em alguns casos com um representante da comunidade, mas apenas se o preço ficar acima do de referência.

O método utilizado torna mais rápido o processo de contratação, mas deixa a comunidade com pouca participação. Além disso, corre-se o risco de haver um “acordo” entre as empreiteiras, aumentando o custo da obra. Há também dificuldade de negociação posterior, pois a empreiteira vencedora da licitação considera-se a “dona” da obra,. Também o método de contratação é um só: material e mão-de-obra diretamente da empreiteira. Pelo menos um avanço tem se verificado: as empreiteiras contratadas são aquelas que eram subcontratadas pelas grandes, as únicas que atendiam às exigências das licitações. Algumas vezes, a contratação nem conta com a participação da comunidade:

Região de Itapeva: o responsável na CESP diz que está "adiantando-se” às comunidades levando a elas o projeto pronto, ou seja, com a empreiteira já contratada. Não se sabe o motivo, mas apenas uma licitação foi feita na região (município de Itararé), mesmo assim com a total ausência da comunidade. Foi 
inaugurado um projeto (Agrovila III) e a comunidade nem sequer ficou sabendo que poderia participar do programa, sendo que esta deve ser a comunidade mais organizada da região. Juntamente com o agrônomo da Casa da Agricultura, foram visitados os bairros dos Ferreiras e Serrinha, para saber qual o grau de envolvimento. Conversou-se com uma moradora do bairro Serrinha, Sra. Maria, que sabia apenas que os trabalhos iriam começar pelo Ferreiras e seriam realizados por apenas uma empreiteira. No entanto, perguntou quando que chegaria a luz na sua casa. Segundo o agrônomo, as comunidades não participaram das reuniões e nem da licitação para se evitar frustrações a essas pessoas caso o programa não fosse implantado, porém elas foram informadas quando o projeto começou a se definir.

Nessa região vê-se também que o programa é bem diferente do planejado. Numa reunião envolvendo a Universidade de São Paulo e empreiteiros também da região, ficou claro que eles estavam fazendo todo o trabalho de cadastramento, obtenção de documentos e orçamentos para a comunidade. Alegavam também estar “quebrando”, pois a Universidade não liberava os recursos para os projetos serem executados. $\mathrm{Na}$ verdade, poucos processos daquela região chegaram à COMTEC, e todos foram aprovados. A CESP transferiu a maioria dos projetos para seu programa paralelo, e atribuiu toda a demora no processo, que passa por ela mesma, pela COMTEC e pela Nossa Caixa, à Universidade, com a intenção de denegrir o modelo.

De modo geral, somente após a escolha da empreiteira é feito o plano de crédito e o banco entra no processo. Assim, o processo de crédito, que deveria estar correndo paralelamente ao técnico, acaba iniciando-se após esse, ocasionando uma demora grande na liberação do financiamento. Essa demora, mais a falta de estrutura de alguns agentes em algumas regiões, fez com que a CESP realizasse o trabalho que caberia a seus parceiros, como já citado. As dificuldades institucionais, descritas no capítulo anterior, também influíram. Em Itapeva, uma obra foi realizada e ligada sem a liberação do dinheiro, fato que veio a ocorrer somente três meses depois, causando dificuldades ao empreiteiro. Seguramente, os problemas de campo contribuíram para que a CESP 
implantasse seu programa paralelo, mas com certeza não foi o único motivo. De novo, a falta de presença física da CERESP no campo traduziu-se em confusão e distorção dos objetivos iniciais.

Após a adoção do programa paralelo, a CESP reduziu seus esforços no "Luz da Terra", conforme mostram seus relatórios à CERESP. O trabalho de cadastramento e os projetos técnicos foram aproveitados no programa paralelo, e os interessados foram compelidos a aderir a ele. Na região de Jales a única opção dada era o programa paralelo, sem mencionar o "Luz da Terra". No Vale do Ribeira, região com 17 municípios e mais de 6.000 cadastrados, a CESP limitou a atuação de consultores da Secretaria de Energia, que foram implantar o programa, a cinco cidades do litoral sul.

Na fase inicial do programa "Luz da Terra", seu coordenador manifestava abertamente que a Secretaria de Energia não conseguia impor suas determinações à Diretoria de Distribuição da CESP. A política assumida pelo governo e instituída pelo decreto do governador, teve a participação de vários atores já citados, inclusive a CESP.

A CESP sabia que a política estabelecida era a política do governador do estado. Houve muitas oportunidades em que as ordens emanadas da Secretaria de Energia - em nome do governo - não se traduziam em ações que levassem aos objetivos de governo, muitas vezes eram ações totalmente contrárias.

Em reunião realizada em 6 de dezembro de 1996, o BNDES se mostrava preocupado com a sorte do programa. Seus funcionários tinham constatado que, em Cunha, o agente da CESP dizia que o programa era de “Alusa” e de "Planel”, duas empreiteiras que mantiveram sólidos laços com a Distribuição da CESP em governos anteriores. Os princípios do modelo do BNDES, segundo o agente, não poderiam ser 
seguidos porque não era o que determinavam as empreiteiras. O interessado não poderia escolher uma empreiteira para a construção da rede, pois a CESP já havia escolhido as duas. Declarara o agente que a CESP não iria permitir que o mutuário do BNDES comprasse o transformador no mercado porque "eram as empreiteiras que iriam vendêlo”.

Disse o representante do BNDES na reunião, textualmente:

“Cuidado! Isto tem cheiro de corrupção”.

Imediatamente o Secretário de Energia tomou a iniciativa de mandar verificar o que se passava e garantiu que não iria acontecer o que o agente da CESP afirmara.

O que ocorre de fato, um ano depois, é que o agente de Cunha informa aos interessados que devem optar pelo programa paralelo da CESP porque é muito mais simples que o do BNDES, sendo que a agência tem e fornece as informações relativas ao programa paralelo mas não pode dar informações precisas sobre o programa "Luz da Terra"; teria que esperar vir de Campos de Jordão alguém que pudesse esclarecer.

A empreiteira que fez boa parte das obras de Cunha - escolhida pela "Planel" tem sua sede no estado do Mato Grosso do Sul.

O transformador, segundo o agente da CESP, pode ser escolhido entre três opções de potência nominal pelo mesmo preço. Então, ele aconselha, em nome da CESP, que se escolha logo o de maior potência nominal, mesmo no caso do consumidor ter demanda pequena.

A política de integração social em torno de uma ação de desenvolvimento de infra-estrutura, que previa o governo de São Paulo atuando, através de vários atores, na 
organização das comunidades marginalizadas, fazendo com que a própria comunidade participe da busca da solução de seus problemas, tem respaldo na Agenda 21 e está em consonância com as políticas sociais planejadas pelo governo federal. Não vigendo na área da CESP, a política da Secretaria de Energia foi substituída por uma política paternalista, com vários elementos que o próprio Secretário declarara estar em desacordo.

Por outro lado, um dos principais executivos da CESP na coordenação da eletrificação rural apresentou sua candidatura à Assembléia Legislativa nas eleições de 1998.

\subsubsection{A Companhia Paulista de Força e Luz}

A CPFL é a companhia de energia que detém a concessão das regiões mais ricas do interior paulista, e não tem a tradição de realizar programas de eletrificação rural. O último foi em 1982, onde foram eletrificadas 517 propriedades. A partir daí, o atendimento se dava quando o cliente, individualmente, solicitava um orçamento à concessionária e esta apresentava seu custo de ligação à vista. Como freqüentemente o valor significava um pesado investimento inicial, a ligação não era realizada. Isto originou uma demanda reprimida, calculada inicialmente em 13.000 possíveis consumidores (CEER, 1995).

Um dado que pode mostrar a pouca receptividade de um programa de cunho eminentemente social entre os engenheiros da empresa é a constatação deles de que “não havia baixa renda na área da Paulista”. Não há ironia: grupos de engenheiros confirmavam, em reuniões, a inexistência de gente pobre nessa parte do território brasileiro! 
Outro dado revela a dificuldade dos técnicos da empresa em entenderem a filosofia da política proposta pelo BNDES: um lugar onde pretendiam lançar primeiro o programa era um reassentamento de agricultores pobres, em lotes agrícolas. Porém, era necessário que todas as ligações fossem trifásicas porque muitos pretendiam instalar motores para a produção.

Este exemplo foi constatado pelo próprio chefe da missão do BNDES: “não sou engenheiro eletricista, mas tenho certeza que o produtor pobre deve ser esclarecido que deve fazer uso de potências instaladas compatíveis com sua capacidade econômica, até por interesse da companhia que não deseja alimentar transformadores e motores em vazio".

Também houve muitas reclamações dando conta que algumas agências da CPFL diziam que em sua área não haveria o "Luz da Terra", e que este era uma iniciativa para atender interesse de políticos, com o que não concordaria a empresa.

Quando a Secretaria de Energia impôs a execução do "Luz da Terra", a CPFL foi a companhia que mais demorou a lançar o programa em campo. Logo após o lançamento oficial, em setembro de 1996, foram realizados lançamentos regionais em outubro e novembro nas cidades de Taiaçu, Bofete, Socorro, Cássia dos Coqueiros e Guararapes. Os lançamentos tiveram conotação eminentemente política, sem grandes responsabilidades operacionais, segundo as próprias palavras da empresa num seminário interno. Esses lançamentos foram realizados como uma resposta à Secretaria de Energia, pois as outras duas concessionárias estaduais já haviam lançado o programa. Depois dos lançamentos, não houve mais nenhuma ação imediata pois estavam esperando o programa “decolar”: “historicamente os programas são lançados, há uma grande mobilização política, mas não é feita uma efetiva operacionalização”. 
Em dezembro do mesmo ano, realizou-se uma série de seminários internos, que tiveram a intenção de explicar os objetivos e passos do programa "Luz da Terra" para as áreas comerciais e técnicas da companhia. Nestes seminários a CPFL instruiu os seus agentes a seguir a política proposta e o fluxograma de operações, com o cuidado de ressaltar que eles deveriam se preocupar estritamente com suas funções, sem realizar as tarefas dos outros agentes. Apesar de visivelmente contrariados, recomendavam que se utilizasse o MRT, de acordo com a instrução técnica aprovada, mas não permitiam o uso do condutor de aço zincado. De modo geral, a empresa achava difícil a implementação do programa e dava pouca ênfase à participação e envolvimento das prefeituras. A participação da comunidade em trabalhos de mutirão não foi citada.

Apenas após os seminários é que começou algum movimento de implantação, concentrado em poucos municípios. O início dos projetos foi previsto para fevereiro de 1997, mas eles só começaram a ser realizados em junho, após ser assinado o contrato com a Nossa Caixa.

O modo de implantação não diferiu muito das outras concessionárias, apenas pode-se dizer que caminhou mais lentamente. A articulação local foi falha, com algumas exceções, como nos municípios de Bofete e Socorro. Em muitas das cidades visitadas havia desconhecimento do programa por alguns agentes, principalmente prefeituras, e informações conflitantes.

O cadastramento mostra-se como o item que mais avançou (6.983 cadastrados em dezembro de 1997), apesar da alegação inicial da empresa. A Secretaria de Agricultura foi a maior fornecedora de cadastros, remetendo os dados do seu projeto LUPA (Levantamento de Unidades de Produção Agropecuária), um recenseamento das 
propriedades rurais paulistas realizado em 1995/1996 ${ }^{5}$. Algumas prefeituras também colaboraram nessa parte.

O maior gargalo na região da CPFL tem sido a pequena capacidade da empresa de fazer projetos elétricos. Em dezembro de 1997, apenas 15 \% dos beneficiários cadastrados tinham seus projetos prontos. Na Regional de Ribeirão Preto essa taxa era de apenas $10 \%$, e desde agosto de 1997 não se faziam novos projetos. Os motivos alegados eram: falta de pessoal decorrente de um programa de enxugamento e aposentadorias, prioridade para a reorganização da empresa, em processo de privatização, prioridade das equipes restantes para outros trabalhos, como iluminação pública e falta de experiência da realização de projetos no sistema MRT.

O processo de contratação de empreiteiras é realizado nos mesmos moldes da CESP. Há relatos também de falta de interesse de empreiteiros em algumas regiões. Em São Joaquim da Barra, a CPFL afirma que: “os empreiteiros desprezam os orçamentos do cliente. Em cidades como Nuporanga, Sales de Oliveira, Aramina, Buritizal e Miguelópolis não havia empreiteiro interessado”. Outras alternativas não são buscadas, como compra direta de materiais e participação da comunidade em mutirão.

Por causa da boa estrutura existente na Nossa Caixa e na Secretaria de Agricultura nas regiões da CPFL, problemas com a elaboração do plano de crédito, com a localização de interessados e com inadimplência não têm sido relatados. Em Socorro, no mesmo dia da abertura de orçamentos os interessados vão à Casa da Agricultura elaborar o plano de crédito e à Nossa Caixa realizar o cadastro. Em Cajuru a Nossa Caixa propunha-se a financiar a parcela de $15 \%$ de responsabilidade dos interessados no período de carência. Em Ituverava a Nossa Caixa relata que os contatos com os

\footnotetext{
${ }^{5}$ Para maiores detalhes sobre esse projeto e sua relação com o programa "Luz da Terra", ver JUCÁ, 1998.
} 
interessados é bastante rápido.

As Prefeituras Municipais têm sido os agentes com participação negligenciada na área da CPFL, apesar de mostrarem-se dispostas a participar:

Ribeirão Preto: há muito tempo atrás o prefeito foi informado sobre o "Luz da Terra" pela própria CPFL. A participação da prefeitura foi "dispensada” pela CPFL sob a alegação de tratar-se de uma cidade grande e de que todos os problemas seriam resolvidos na Agricultura e na própria concessionária;

Cravinhos: nenhuma informação sobre o programa. A prefeitura queria que fosse procurada a Casa de Agricultura para qualquer esclarecimento;

Cajuru: não havia conhecimento dentro da prefeitura dos passos a serem seguidos dentro do programa "Luz da Terra". Havia apenas conhecimento sobre linhas trifásicas e seu alto custo. Desta forma acreditou que (fazer) ligações monofásicas seriam inúteis. Após os esclarecimentos sobre o programa e seus objetivos houve grande interesse e foi perguntado como a prefeitura poderia atuar dentro do "Luz da Terra";

Distrito da CPFL em Franca: não há envolvimento das prefeituras no programa. "Ninguém orientou o distrito para envolver a prefeitura";

Batatais: "O governo lança coisas úteis mas não chegam às prefeituras. Nenhum material chegou à prefeitura”. (...) O prefeito deseja um retorno de parte da população urbana para o campo: "Sujeito não volta sem a luz. Ele quer conforto. Queremos $10 \%$ desses trabalhadores de volta para o campo”.

Apesar dos trabalhos de campo terem sido realizados de forma truncada e lenta, no município de Bofete ocorreu um processo que mostra que o programa "Luz da Terra" é exeqüível quando há o comprometimento da concessionária, o envolvimento dos agentes locais e a participação da comunidade.

Nesse município, a Universidade de São Paulo participou da inauguração de uma obra atendendo 58 interessados no Bairro do Jacutinga. Na cerimônia, o programa "Luz da Terra" foi elogiado pela prefeitura, pelos moradores rurais e pela CPFL. Segundo os técnicos, aquela comunidade vinha solicitando a energia elétrica desde 1977 
mas, por causa dos altos custos do projeto e da falta de programas específicos na empresa, não havia ainda conseguido a luz.

Este projeto foi o primeiro no sistema MRT feito pela CPFL, viabilizado com o apoio e a vontade dos técnicos:

"no começo nós não sabíamos como projetar nesse sistema, mas veio a ordem e nós falamos: vamos fazer! E não é que funciona mesmo... Teve lugar que era tão íngreme que só com o MRT para chegar lá”.

Um ponto importante foi o convencimento da comunidade, segundo a CPFL:

"o povo aqui já estava cansado de ouvir falar em eletricidade. Teve pessoa que saiu atrás da gente com espingarda. Só se você fosse com um vizinho ou conhecido ele te ouvia. Nós chegamos a projetar as redes dentro das propriedades de propósito, para obrigar o cara a participar, vendo a rede na sua porta. É um pessoal simples e desconfiado, mas muito bom. Alguns chegavam a nos ajudar, puxando trena. Um senhor levou duas galinhas para o pessoal da empreiteira”.

A comunidade mostrou que conseguiu se organizar, segundo as palavras do líder

dos interessados:

"eu acho que agora nós conseguimos a luz porque o pessoal tava mais disposto. Dois sobrinhos meus entraram e na última hora desistiram. Isto iria parar todo o processo. Fomos atrás de um outro morador que não queria pois já estava aposentado e morava na cidade, tinha luz lá. Conversamos com ele e ele falou: se é para ajudar todo mundo e fazer o negócio andar pode pôr meu nome”.

O processo levou a empresa a refletir sobre a redução de custos:

"nós achamos que dá para reduzir mais o custo. Numa próxima obra vamos ver se a comunidade participa fazendo os buracos, dando alojamento $e$ alimentação”.

O próprio empreiteiro se mostrou favorável à participação da comunidade com trabalho:

"se eu encontrasse os buracos feitos, eu iria reduzir meu orçamento, pois tive que pagar eletricistas para fazer esse serviço. Às vezes levava um dia inteiro para fazer uma cava pois o terreno é duro". 
O processo fez com que alguns técnicos comprassem a proposta do programa, pelo contato que tiveram com a comunidade (no fim, já conheciam todos pelo nome) e pela possibilidade de atenderem uma antiga demanda. Isso permitiu que acontecesse uma mudança de mentalidade: “no Seminário Técnico nós dávamos risada: esses caras são doidos, não funciona”, inclusive com a aceitação do sistema MRT: “se no Sul funciona, porque não aqui?”. O apoio do núcleo regional foi bem importante, deixando os técnicos trabalhando em tempo integral no programa, deslocados de outras funções. Ao mesmo tempo, os técnicos mostram-se apreensivos quanto ao futuro:

“como vai ficar com a privatização? Será que vão continuar investindo? No começo para fazer as primeiras ligações a pressão foi grande, depois houve pouca cobrança”.

O processo desse bairro mostrou que o modelo proposto pelo programa é perfeitamente executável, contrariando argumentação das outras empresas e da própria CPFL. A empresa fez uma experiência e comprovou a eficácia do modelo, mostrando que um exemplo bem sucedido contamina positivamente as expectativas dos agentes. Apesar de não terem sido usadas todas as possibilidades de redução de custos, como mutirão, uso de condutor de aço, melhor política de compras, o custo médio por consumidor ficou em $\mathrm{R} \$ 1.710,36$, com financiamento de todos pelo BNDES, custo esse bem menor que o praticado anteriormente (segundo os moradores, de 4 a 5 mil reais).

\subsubsection{A Secretaria de Agricultura}

A Secretaria de Agricultura e Abastecimento do Estado de São Paulo é o ator de maior presença no estado. Em cada município com certa área rural (como é a maioria dos 645 municípios do estado) há uma Casa da Agricultura (cerca de 600 em 1997), que 
é composta por um agrônomo e um número variável de técnicos agrícolas. Estas casas são coordenadas por 40 Escritórios de Desenvolvimento Rural (EDR), ligados à Coordenadoria de Assistência Técnica Integral (CATI), órgão da secretaria com sede em Campinas. Recentemente houve um processo de municipalização das Casas da Agricultura, que transferiu a responsabilidade pela administração e contratação de funcionários para as Prefeituras Municipais. Hoje já são aproximadamente 550 Casas da Agricultura municipalizadas.

Toda essa estrutura poderia ter contribuído para que o programa tivesse sido melhor sucedido. À parte o não cumprimento da alteração na lei do FEAP (que é ligado à Secretaria) já descrito no capítulo 3, houve também uma dificuldade inicial da Secretaria de Agricultura nas ações de campo. A fase de transição causada pela mudança de secretário na época de lançamento do programa, ou seja, no momento de início da implantação em campo, certamente contribuiu para isso. O programa foi visto como sendo do secretário anterior, em fase de desavenças políticas com o governo e desafeto político do atual.

O principal suporte do PROLUZ, no Rio Grande do Sul, foi a atuação das Prefeituras Municipais e da extensão rural. O processo era liderado por tais atores. Na implantação do programa "Luz da Terra", a Secretaria de Agricultura tomou outra atitude. O entendimento era que a iniciativa deveria partir da concessionária, até porque tradicionalmente era assim que a eletrificação rural foi feita. A Secretaria de Agricultura assumiu um papel passivo: sua única função era fazer os planos de crédito, isto quando não eram regiões onde ela tinha mais deficiências, como o Vale do Ribeira. O público a ser atendido talvez contribuísse para essa atitude: moradores e trabalhadores rurais, produtores de subsistência, chácaras de lazer, pequenos proprietários; público que não é 
o preferencial das Casas da Agricultura. Tampouco o programa foi visto como sendo de extensão rural, como inicialmente planejado. Não houve uma estratégia, dentro da Secretaria, visando fazer com que o programa de eletrificação rural fosse uma porta de entrada para a melhoria da produção agrícola.

Salvo exceções, a desinformação dos agrônomos era grande:

Artur Nogueira: quando se falou sobre o programa o agrônomo da Casa da Agricultura mostrou-se surpreso com a quantidade de informações. Ficou decepcionado ao verificar que existia até um "manual orientativo" e que a Secretaria de Agricultura havia apenas mandado um prospecto do que seria o programa: "Nós recebemos apenas alguns folders, com as fichas de inscrição, $e$ as informações neles contidas. Foi só isso! ”

Joanópolis: na Casa da Agricultura conversou-se com dois agrônomos de outra cidade (pois Joanópolis no momento está sem agrônomo na Casa da Agricultura). Nesta conversa, foi comentado que faltaram mais informações sobre este programa, pois ele só obteve todos os dados necessários para fazer a sua parte cerca de uma semana antes de começar a receber as pessoas interessadas e preparar a documentação delas.

Ribeirão Branco: os agrônomos obtiveram informações sobre o programa de um agente da EDR em fevereiro de 1997. Sabiam que poderia ser feita a equivalência em produto, mas não estavam informados sobre a avaliação do rendimento anual para avaliar o financiamento ao produtor.

Havia também receio de se envolver muito:

Itararé: o secretário da agricultura municipal diz haver receio por parte da Secretaria de Agricultura e da prefeitura em envolverem-se diretamente no programa "Luz da Terra" e depois os projetos não serem executados. Segundo ele, isto faria com que as comunidades rurais perdessem a confiança naqueles órgãos, pois esta confiança foi conquistada em quatro anos de trabalho e não pode ser perdida pelo insucesso de um programa. A perda de confiança do secretário nos projetos do governo se deu por causa dos planos anteriores de eletrificação rural não terem tido bons resultados.

Em alguns municípios, as Casas da Agricultura atuavam no cadastramento e divulgação. Em Porangaba, Itaberá, Pilar do Sul, Piedade e Coronel Macedo as Casas da Agricultura apenas cadastraram e enviaram os dados para a CESP, sem nenhuma outra ação. 
Em outras regiões, reclamavam que a concessionária não dava espaço, principalmente a CESP:

Guaratinguetá: o agrônomo da EDR, que atende municípios da Eletropaulo e da CESP, mencionou a falta do termo de compromisso do FEAP e a falta de planejamento das atividades a serem executadas, principalmente em relação à CESP. Citou a falta de comunicação entre os órgãos envolvidos, demonstrando um extremo individualismo destes setores. Demonstrou grande interesse em participar de reuniões e discussões promovidas pela CESP e Casa da Agricultura com as comunidades, mas dificilmente é convidado.

Capão Bonito: segundo os representantes dos órgãos a CESP, juntamente com as empreiteiras, estão fazendo tudo no programa.

Houve problemas também de estrutura, como falta de pessoal e veículos, principalmente nas regiões mais pobres. Isto atrasou a confecção de planos de crédito em regiões como Atibaia, Cunha e o já citado Vale do Ribeira, onde a CESP colhia os dados.

Em alguns dos lugares onde a Secretaria demonstrou maior interesse pelo programa a implantação do programa paralelo da CESP tumultuou o processo. Na região de Jales, as Casas da Agricultura reuniram os agricultores e divulgaram as diretrizes do programa "Luz da Terra", principalmente com relação aos quesitos de financiamento. Os cadastros foram remetidos à CESP, que passou a convocar os agricultores oferecendo seu programa, com pagamento em dez vezes, numa parcela mensal equivalente a R\$100,00. Caso o agricultor não quisesse, era obrigado a assinar uma declaração de que não estava interessado na energia elétrica. Como o valor a ser pago era elevado, muitos agricultores passaram a cobrar dos agrônomos a condição anteriormente oferecida, deixando-os numa situação difícil, pois a CESP não fornecia os projetos técnicos. 
Para a coordenação do programa, a CESP dizia que os agricultores não queriam o "Luz da Terra". Na verdade, não queriam o programa CESP nas condições oferecidas, que inclusive tinha esgotado sua verba para a região e não previa novas ligações, nem pelo "Luz da Terra".

A situação só começou a ser esclarecida com a ida a campo do responsável pelo programa na Agricultura, de pesquisadores da Universidade de São Paulo e de consultores da CERESP. Prevê-se que, a partir dessas visitas, se normalize a situação e implante-se o programa "Luz da Terra" nos moldes estabelecidos.

De modo geral, a atuação da Secretaria de Agricultura fica a reboque da articulação local. Onde esta é bem realizada, como em Bofete, Socorro ou mesmo Pindamonhangaba, não se verificaram muitos problemas quanto à sua atuação. A atitude da Secretaria tem sido tímida e reativa, embora nos últimos meses tempos tenha havido um interesse maior em se engajar no processo, fruto de uma melhor compreensão do programa e das pressões recebidas no campo e na CERESP.

\subsubsection{A Nossa Caixa Nosso Banco}

A Nossa Caixa Nosso Banco é o banco estadual encarregado de repassar os recursos aos beneficiários, em operações de crédito individuais, porém ligados a um projeto coletivo. Para isso, celebrou um contrato de empréstimo bancário com outra casa bancária, o BNDES, colocando sua rede de cerca de 530 agências, espalhadas pelo estado, à disposição do programa "Luz da Terra".

Os procedimentos bancários são regidos por normas bastante rígidas do Banco Central e da Federação Brasileira dos Bancos (FEBRABAN). Para a concessão de 
crédito, é necessário que o beneficiário não esteja inadimplente com alguma dívida e não possua seu nome inscrito nos serviços de proteção ao crédito. Além disso, necessita da documentação básica, CPF e RG, além de um comprovante de residência, que pode ser substituído por uma declaração da prefeitura. Outro ponto importante é que todos os participantes de um projeto precisam ter sua documentação regularizada. Se apenas um beneficiário não estiver nessa situação, o crédito não é liberado. Após a concessão do crédito, é necessário ainda que cada interessado assine individualmente um contrato de financiamento.

As recomendações são bastante simples para o público com que o banco está acostumado a trabalhar. Mas, para o tipo de público atendido pelo programa "Luz da Terra", muitas das exigências passam a ser dificuldades intransponíveis, se não existir assessoria às comunidades. Houve processos, em Registro, que demoraram um ano para serem concluídos, por dificuldades em cada um daqueles pontos.

O banco, num processo de crédito, freqüentemente é um agente passivo. O modo normal de trabalhar é esperar as pessoas na agência ou, no máximo, deslocar um funcionário até uma comunidade para recolher as assinaturas, durante um horário estabelecido. O programa previa exatamente isso. A sociedade local, articulada pela prefeitura ou pela comissão municipal, deveria trabalhar o processo de modo que as pendências, como falta de documentos e inadimplências, fossem resolvidas. Como não existiu essa articulação, o próprio banco teve que resolver esses problemas, não conseguindo fazê-lo de modo satisfatório.

Havia também poucas informações sobre o programa. Os gerentes locais receberam um comunicado sobre a sua existência, mas não foram acionados pela concessionária ou pela comissão municipal para realizar a triagem preliminar. Em 
regiões mais carentes, como no Vale do Ribeira, onde uma agência da Nossa Caixa atende 11 municípios numa demanda estimada de 5.600 beneficiários, a situação tornou-se crítica. Todos os problemas que deveriam ter sido resolvidos antes do processo ser enviado para o banco acabavam sob a sua responsabilidade. A falta de articulação local também contribuía para aumentar as dificuldades:

Gerente da Nossa Caixa em Iguape: "Tenho que me deslocar 80, $90 \mathrm{~km}$ até a cidade mais próxima para levar os contratos para serem assinados. Metade da comunidade assina, a outra faltou ou não assina. Uma pessoa assumiu quatro contratos e morreu recentemente. As pessoas são localizadas com muita dificuldade. Um funcionário ficou agoniado por não conseguir entrar em contato com um homem que não voltava do bananal. Gostaria que enviassem dados corretos e completos para a Caixa. Existem muitos casos com falta de documentação básica. Queremos dados básicos para uma pessoa que existe! Casado? Solteiro? Dados do cônjuge? Dados da emissão do RG? Quando nasceu? Os projetos liberados contam com a maioria das pessoas mais instruídas; são estas pessoas que conseguem fazer o processo andar. Os mais ricos pressionam os mais pobres para não desistirem e o projeto poder sair. Também não há preocupação da renda das pessoas na hora do cadastro. Uma pessoa não quis assinar porque não teria dinheiro para pagar o financiamento; foi convencida e assinou o contrato. E quando a luz chegar? Ele vai pagar? Daqui a dois anos culparão a gerente por um cadastro mal feito. Tenho necessidade de um cadastro decente. Caso contrário não posso aprovar. Há posseiros querendo ligação. Daqui a um ou dois anos estas pessoas se mudam e quem se responsabiliza?”

Os comentários dessa gerente mostram a preocupação em resolver os problemas, a disponibilidade de atuar, mesmo em tarefas que não eram estrita obrigação do banco e a dúvida quanto à sustentabilidade dos projetos. Vale lembrar que a região do Vale do Ribeira é a mais pobre do estado, onde há muitas ligações de pessoas de baixa renda que a CESP não encontrou meios de executar, conforme o compromisso assumido.

Um outro processo, que mostra que um número muito grande de interessados num mesmo projeto traz dificuldades de gerenciamento, foi o do Bairro Água Branca/Moenda, em Mongaguá. Dos 174 beneficiários, havia 40 pessoas sem documentos, 34 pessoas com restrições bancárias e 44 pessoas que não compareceram 
para assinar os contratos de financiamento. Como a triagem bancária iniciou-se após ter sido obtido o orçamento, o processo levou aproximadamente 300 dias para sua conclusão, apesar de contar com o apoio da prefeitura e de um vereador que realizou o trabalho de campo.

Quando há uma certa articulação e a comunidade consegue se organizar, não se reportam problemas. Em Bofete, a assinatura de 54 contratos levou apenas 2 dias.

A Nossa Caixa também estava autorizada a cobrar uma taxa de até $\mathrm{R} \$ 30,00$, a título de despesas de cadastro. Essa informação muitas vezes não era passada à comunidade que, no momento de assinar os contratos, reclamava por estar pagando antes de receber a energia elétrica.

Uma outra exigência, que existia no início, era a necessidade de um avalista para as pessoas com renda anual acima de $\mathrm{R} \$ 7.500,00$, sendo um fator limitante ou, no mínimo, complicador, em algumas regiões. Essa exigência foi retirada por iniciativa do Departamento Rural do banco, passando ele então a assumir o risco de inadimplência desses beneficiários.

A falta de informação das comunidades e a demora na resolução das pendências fez com que, no campo, o banco ficasse com a imagem de estrangulador do processo. Na maioria das vezes, estava na comunidade ou na concessionária a responsabilidade pela resolução dos problemas, mas a percepção foi de que o banco era o entrave. Os outros atores, principalmente as empresas de energia, não compreenderam as vicissitudes inerentes aos procedimentos bancários, adotando a atitude mais fácil de criticar e jogar a culpa no banco. Chegaram inclusive a fazer propaganda negativa do 
financiamento em áreas como na regional Oeste da Eletropaulo e em regiões onde o programa paralelo da CESP foi implantado.

De modo geral, as agências da Nossa Caixa cumpriram seu papel quando solicitadas, mas a falta de articulação local fez com que tivessem que desempenhar tarefas para as quais não estavam preparadas, retardando e paralisando os processos.

\subsubsection{As Concessionárias Privadas e as Cooperativas de Eletrificação Rural}

No estado de São Paulo, a distribuição de energia elétrica não é realizada apenas pelas três concessionárias estaduais, todas em processo de privatização. Há, ainda, concessionárias de capital privado e permissionárias, como as cooperativas de eletrificação rural.

Em 1994, existiam nove empresas de distribuição privadas atendendo 109 municípios. Assim como não houve, dentro da história da eletrificação rural do estado de São Paulo, um programa que envolvesse as três concessionárias estatais, não houve também programas específicos, em nível estadual, que envolvessem a participação dessas concessionárias. Assim a evolução da eletrificação rural nessas empresas deu-se conforme a legislação vigente e os programas federais.

No programa "Luz da Terra", a estratégia adotada foi a de primeiro implantar e consolidar o programa dentro das empresas estatais para depois estendê-lo às concessionárias privadas.

No decorrer do primeiro ano, apesar de não ficar configurada essa consolidação do programa, algumas das empresas particulares aderiram a ele, celebrando convênios com a Nossa Caixa. Essa adesão foi em parte fruto da vontade dessas empresas, em 
parte decorrente da pressão no campo. Em fins de 1997, as empresas: EEVP, Caiuá e Sul Paulista já tinham seus convênios assinados, e a Santa Cruz estava em fase de negociação. Como a implantação e a adesão são recentes, pouco pode-se analisar a respeito da prática dessas empresas. A tendência é que se repita o observado nas outras companhias. No município de São Miguel Arcanjo, atendido pela Sul Paulista, a prefeitura, incentivada pela Nossa Caixa, solicitou a visita de representantes da CERESP para explicar o programa. Em visita à concessionária, verificou-se que o cadastramento já estava ocorrendo e os outros agentes não sabiam, ou seja, o desencontro de informações era grande. Nessa mesma empresa, havia restrições ao uso do MRT, considerado de pouca confiabilidade, assim como na Santa Cruz, cuja diretoria proibiu sua utilização. A Caiuá submeteu alguns projetos à apreciação da CERESP que utilizavam sistemas trifásicos e postes de concreto.

De modo geral, percebe-se que a CERESP e a Secretaria de Energia ainda não possuem estratégias para atuar junto a essas empresas. Elas sequer participam das reuniões ordinárias da CERESP.

Outro tipo de empresa que faz a distribuição de energia elétrica no estado são as cooperativas de eletrificação rural. Elas não detém direito de concessão em suas áreas de atuação, mas possuem uma permissão do antigo Departamento Nacional de Águas e Energia Elétrica (DNAEE) para exercer suas atividades. A origem dessas empresas foi a associação de consumidores rurais que não eram atendidos pelas concessionárias, pela falta de interesse econômico. Estes consumidores se associavam em cooperativas para efetuar a construção e operação de redes elétricas, acessando financiamentos internacionais, segundo um modelo adotado pelos Estados Unidos na década de 30. Com o passar do tempo, algumas dessas cooperativas acompanharam o 
desenvolvimento de suas regiões, chegando a atender sedes de municípios, como se fossem pequenas concessionárias. As cooperativas de eletrificação rural se organizam através de federações estaduais e de uma confederação nacional. Em São Paulo, a Federação das Cooperativas de Eletrificação Rural do Estado de São Paulo (FECOERESP) participa da CERESP na condição de convidada.

O engajamento das cooperativas no programa foi diverso. A Cooperativa de Eletrificação e Telefonia Rurais de Ibiúna (CETRIL), apoiada pela Eletropaulo, logo demonstrou interesse, tendo já contratado 522 ligações com a Nossa Caixa e elaborado até um cartaz especial para divulgação, enquanto a Cooperativa de Eletrificação Rural de Itaí, Paranapanema e Avaré (CERIPA) aderiu ao programa por pressão da prefeitura de Paranapanema. As outras cooperativas até o momento não formalizaram o interesse às vezes manifestado.

Um ponto que facilitou a contratação de financiamentos pela CETRIL foi sua decisão de avalizar os beneficiários, através de um convênio firmado com a Nossa Caixa. Outro arranjo proposto foi que a cooperativa poderia construir as redes, desde que estas fossem fiscalizadas pela Eletropaulo. Assim, o dinheiro foi repassado diretamente para a cooperativa. A parcela de $15 \%$ foi também financiada pela CETRIL aos beneficiários em seis vezes. O custo de cada ligação foi de R\$ 1.056,77, em média. Esse baixo valor talvez tenha sido conseguido pela iniciativa de ligar as pessoas mais próximas à rede. Foram descartadas aquelas ligações que estavam muito distantes. Numa segunda etapa a tendência é de aumento de custos, sendo necessária uma maior discussão a respeito dos valores cobrados, dos critérios técnicos da rede e do uso de mutirão, pontos em que não houve discussão na etapa realizada. A CETRIL mostrou 
grande interesse pelo programa, e se empenhou em executá-lo, pois vê nele uma oportunidade de expandir seu mercado.

Como curiosidade, um dos cooperados atendidos pela CETRIL, com um transformador de $10 \mathrm{kVA}$, é o senhor Fernando Henrique Cardoso, em um sítio situado na área rural de Ibiúna.

Na CERIPA a atitude foi diferente. A eletrificação de consumidores com baixa rentabilidade era apresentada como um "favor" de cunho puramente "social”. O diretor deixou claro que a cooperativa não tinha interesse nesse tipo de atendimento. Não aceitaram discutir tecnicamente os projetos, que claramente podiam ser otimizados, nem os custos, que envolviam a cobrança de uma "jóia”6. A solução proposta pela cooperativa para abaixar o custo médio, que era de cerca de $\mathrm{R} \$ 1.700,00$, foi a exclusão daqueles consumidores que estavam mais distantes da rede. Foi necessária a intervenção da prefeitura de Paranapanema e a participação desta com uma parcela em dinheiro para viabilizar o atendimento a todos os consumidores.

\subsubsection{As Prefeituras Municipais}

Rigorosamente, a Prefeitura Municipal não tem nenhum papel executivo no programa. Porém, cabe-lhe realizar tarefas fundamentais no processo, pois é o ator que mais facilmente pode conseguir mobilizar a população e a sociedade para o programa de eletrificação rural, através da identificação de lideranças comunitárias, da

\footnotetext{
${ }^{6}$ Geralmente as cooperativas adotam o procedimento de cobrar uma certa quantia para a entrada de um novo cooperado. Este é obrigado a comprar uma "cota-parte" do patrimônio da cooperativa, chamada de “jóia”, calculada de maneira quase sempre inacessível aos interessados. Esta "jóia” é embutida no custo de construção da rede. Na CERIPA estimou-se que isso dobrava o custo das ligações. Embora a legislação faculte essa cobrança, ela ainda é bastante comum.
} 
disponibilização de funcionários e do engajamento de vereadores. Para isso, compete à Secretaria de Energia a convocação política dos prefeitos.

A prefeitura, por conhecer seu município, pode identificar melhor os futuros beneficiários, ajudar no cadastramento, na obtenção de documentos, no convencimento dos renitentes, na busca de orçamentos, na identificação dos beneficiários de baixa renda, na organização de compras de materiais e de mutirões, além de coordenar o programa no município, assumindo sua liderança.

O programa "Luz da Terra" previa, na etapa de articulação local, o envolvimento das prefeituras. O que se verificou, porém, foi que a maioria delas não foi envolvida ou ficou omissa. O seu chamado à ação, liderado pelas concessionárias, não explora todo o potencial de participação. As ações não foram homogêneas. As três concessionárias estaduais adotaram diferentes maneiras de abordar as prefeituras.

Na CESP e CPFL, não se enfatizava a necessidade de participação da prefeitura. Com isso, a maior ação ficou sendo a ajuda no cadastramento, com exceções onde a prefeitura percebia que poderia ajudar mais (Mongaguá, Joanópolis).

Na Eletropaulo, o processo ocorria de modo diverso. Já na primeira reunião era solicitada da Prefeitura Municipal a colaboração, e até tentativas de formação de uma comissão municipal foram realizadas. No entanto, após a cerimônia de lançamento oficial, os projetos entregues às comunidades caíam num “vazio”, não conseguindo-se acompanhar seu andamento. Raras eram as prefeituras que se dispunham a acompanhar e assessorar as comunidades por sua própria iniciativa, como em Salesópolis e Araçoiaba da Serra. 
Por outro lado, em nenhuma das prefeituras visitadas pela Universidade de São Paulo houve desinteresse quando o programa era apresentado. Todas, umas mais, outras menos, mostravam-se dispostas a contribuir para um melhor andamento dos processos. O principal motivo alegado para não estarem participando foi o desconhecimento do que poderiam fazer. Algumas, com o processo em andamento, perguntaram: “o que vocês precisam da prefeitura?” (Prefeito de Cananéia) ou “a prefeitura quer ajudar, mas não sabe no quê. Precisa informar!” (Prefeito de Monteiro Lobato). Pode-se concluir que foi a falta de informação e de acompanhamento sistemático que levou à inércia das municipalidades.

Um exemplo de como a prefeitura, e a ação política do prefeito, pode contribuir para o programa foi dado pela Prefeitura Municipal de Paranapanema.

O município de Paranapanema é atendido por uma concessionária privada, a Companhia de Força e Luz Santa Cruz e uma permissionária, a CERIPA. Logo, não seria incluído de imediato no programa "Luz da Terra", pois a prioridade era trabalhar com as três concessionárias estatais. O prefeito, porém, tomou conhecimento do programa e foi se informar na Secretaria de Energia sobre os procedimentos necessários. Levou consigo seu Secretário da Agricultura Municipal, também agrônomo da Casa da Agricultura local, para realizar a parte executiva do processo.

Iniciou-se então a etapa de cadastramento. A prefeitura visitou as comunidades, ajudou as pessoas a tirarem seus documentos, elaborou os planos de crédito simplificados e resolveu as pendências bancárias com a Nossa Caixa. Verificou-se que a maioria dos atendimentos (cerca de 90) deveria ser feita pela cooperativa e o restante (aproximadamente 30), pela Santa Cruz. 
Surgiu então um problema. A cooperativa apresentou custos de ligação muito altos, e não abria mão de construir ela própria as redes. O programa "Luz da Terra" não permite que uma permissionária seja a construtora sem que a concessionária fiscalize a obra. No caso, a Santa Cruz não poderia fazer isso pois não havia assinado o contrato com a Nossa Caixa, e tem restrições muito fortes ao uso do MRT. Percebendo o impasse, o prefeito voltou à Secretaria solicitando auxílio.

A Comissão Técnica e a Universidade de São Paulo foram até o município procurar soluções. Como já dito, a cooperativa mostrou-se intransigente e não aceitou discutir os custos. A solução encontrada, então, foi a prefeitura entrar com uma parcela em dinheiro e um rearranjo dos beneficiários. Os de maior capacidade financeira, selecionados pela prefeitura, que conhecia todos os participantes e tinha como convence-los, pagariam sua ligação à vista ou financiariam até o teto de R\$2.000,00, respeitando a proporcionalidade de 25 \%. A Comissão Técnica ficou encarregada de fiscalizar as obras, que se iniciam em fevereiro de 1998.

A liderança e a vontade da prefeitura, junto com a participação da Secretaria de Energia e da Universidade de São Paulo foram fatores determinantes para viabilizar o atendimento. Uma das comunidades beneficiadas é um núcleo de pescadores que poderá aumentar sua renda conservando os peixes que antes pescavam e eram obrigados a vender no mesmo dia, à beira da estrada. Se não o fizessem, eles se estragavam, por falta de refrigeração.

\subsubsection{A Universidade de São Paulo}

A Universidade de São Paulo participou das atividades de campo como observadora e avaliadora dos procedimentos adotados. Nesse sentido, fez várias 
sugestões para a correção de ações que julgava estarem fora das linhas que foram adotadas. Durante o mês de julho de 1997, enviou a campo uma equipe de 13 estagiários que visitaram 66 municípios (mais de $10 \%$ do estado, traçando diagnósticos e divulgando o programa aos órgãos locais. Isto causou surpresa em pelo menos um município:

Aguaí: o secretário ficou surpreso somente com a participação da Universidade de São Paulo no programa e, de certa maneira, desconfiado. "Qual é o interesse da USP em que o programa ande mais rápido? Eu estou perguntando isso porque nunca aconteceu de alguém vir de São Paulo somente para enfatizar a importância de um programa estadual”.

A Universidade de São Paulo também participou na assessoria ao programa, elaborando um banco de dados de preços de materiais, um plano de divulgação do programa dentro do município, um manual orientativo contendo as suas diretrizes básicas e divulgando esse material aos agentes locais, fabricantes, empreiteiras e comunidades.

Em relação às concessionárias, o relacionamento foi diferente. A Eletropaulo vê a Universidade como parceira importante, e sempre a convida para as suas reuniões com as prefeituras e cerimônias de lançamento. Já a CESP e CPFL não dão essa importância, não convidando ou avisando, na maior parte dos casos, a Universidade dos seus eventos, mas não se opõem quando ela se propõe a visitar municípios em sua área de concessão.

A Universidade, que tem como uma de suas funções a prestação de serviços à comunidade, celebrou também um convênio de pesquisa com a Eletropaulo, do qual participam a CESP e a CPFL, para estudar temas relacionados ao programa como, entre outros, a definição dos padrões de redes e o desenvolvimento de metodologias para incentivar a participação comunitária, além do acompanhamento do programa propriamente dito. 
Outra instância em que a Universidade tem atuado, além das ações em nível institucional, é na Comissão Técnica que analisa os processos de eletrificação rural enviados pelas concessionárias, possuindo o voto de qualidade. Uma atuação informal, importante, nem sempre solicitada, tem sido a de servir como ponte entre os agentes locais e a coordenação do programa, visando esclarecer pontos obscuros e pendências, em casos como os dos municípios de Mongaguá, Araçoiaba da Serra e São Miguel Arcanjo.

\subsubsection{A questão dos custos - fabricantes e empreiteiras}

Os custos dos projetos de eletrificação rural estão intimamente ligados aos padrões técnicos utilizados e à forma de construção das redes. Na implantação do PROLUZ, os menores custos foram observados onde houve a construção de redes por mutirão, conforme as matrizes de implantação observadas (ROSA et al., 1993):

\section{Tabela 5}

Matrizes de Implantação - Programa PROLUZ

\begin{tabular}{ccccccc}
\hline Matriz & $\begin{array}{c}\text { Concessionário/ } \\
\text { Permissionário }\end{array}$ & $\begin{array}{c}\text { Órgão } \\
\text { Coord. } \\
\text { Local }\end{array}$ & $\begin{array}{c}\text { Treinamento } \\
\text { Rec. Hum. } \\
\text { na P. M. }{ }^{7}\end{array}$ & $\begin{array}{c}\text { Agente } \\
\text { Técnico }\end{array}$ & $\begin{array}{c}\text { Forma de } \\
\text { Execução }\end{array}$ & $\begin{array}{c}\text { Custo Méd. } \\
\text { por cons. } \\
\left(\text { US } \$^{8}\right)\end{array}$ \\
\hline 1 & CEEE/RS & P. M. & Sim & Equipe Próp. & Mutirão & 666,63 \\
\hline 2 & CEEE/RS & P. M. & Sim & Empreiteira & Mutirão & 779,05 \\
\hline 3 & CEEE/RS & P. M. & Não & Empreiteira & Empreiteira & 835,34 \\
\hline 4 & Cooperativa & P. M. & Sim & Cooperativa & Mutirão & 448,53 \\
\hline 5 & Cooperativa & P. M. & Não & Cooperativa & Empreiteira & 798,72 \\
\hline
\end{tabular}

\footnotetext{
${ }^{7}$ P. M. - Prefeitura Municipal.
}

${ }^{8}$ Dólares americanos de 1993. 
O treinamento de recursos humanos nas Prefeituras Municipais era para que esta realizasse os serviços de mão-de-obra especializada e orientasse a comunidade no fornecimento de mão-de-obra não especializada no sistema de mutirão.

O relatório final desse programa concluiu que (BANRISUL, 1993):

- o custo médio nominal por consumidor ficou em US\$ 735,00;

- as matrizes de implantação onde houve treinamento de recursos humanos das Prefeituras Municipais (através de Consultoria Especializada - matrizes 1, 2 e 4) apresentaram os menores custos por consumidor;

- as matrizes de implantação onde não houve capacitação de recursos humanos das Prefeituras Municipais (matrizes 3 e 5) apresentaram maior custo nominal por consumidor.

O custo médio de financiamento por consumidor do programa "Luz da Terra", previsto em R $\$ 1.200,00$, estava em R\$ 1.099,58 num universo de 1.552 contratos em dezembro de 1997.

A proporcionalidade, porém, tem sido uma grande preocupação. O programa prevê que apenas 25 \% das ligações tenha valor financiado acima de R\$1.200,00, com o teto em R $\$ 2.000,00$, como forma de controlar a dispersão dos custos. Segundo dados da Nossa Caixa, a proporção estava em 33 \%. Ou seja, há ligações com custo baixo, mas também uma grande parcela têm o custo mais elevado.

Observa-se que ainda há grandes possibilidades de redução de custos dentro do programa. Os projetos técnicos ainda possuem espaço para otimização. É prevista a possibilidade de construção de redes em mutirão mas, nas obras realizadas, raras são as 
que utilizaram a mão-de-obra da comunidade. Mesmo onde isso aconteceu, não foi aproveitado todo o potencial. As compras de materiais são realizadas pelas empreiteiras e repassadas à comunidade, com um custo adicional.

Na realidade, a preocupação com os custos é apenas uma: que estejam próximos do custo de referência. A prática usual é contratar a obra completa da empreiteira, material e mão-de-obra, em regime de turn-key. Isto provoca um grande controle da empreiteira sobre os custos. A diretriz proposta pelo BNDES, de que o objetivo não é realizar ligações a R\$ 1.500,00, mas sim ao menor custo possível, é desprezada. Prevêse também a explosão do custo da obra em vários itens, para facilitar a negociação de cada um. O que tem ocorrido é a apresentação de um preço global para a obra e depois a empreiteira preenche as planilhas de itens, provocando grandes disparidades. Em Socorro, a mesma empreiteira cobrou R\$ 10,00 para fazer uma cava para poste na terra de uma comunidade e R\$ 30,00 para outra, e ninguém convocou a comunidade para realizar esse trabalho e evitar gastar R\$ 30,00. Em Mongaguá o item “ferragens em geral” estava R\$ 10.000,00 acima do preço de referência.

As empreiteiras reclamam de dificuldades na realização de obras e também mostram-se cépticas quanto ao mutirão:

Socorro: a CPFL acha que o mutirão tem problemas de segurança e relata que os empreiteiros abatem muito pouco do preço final;

Itanhaém: Foi levantada a questão do mutirão. É uma questão simples, o empreiteiro argumenta: "É só falar que a comunidade já passa o facão na mata. Mas quem se responsabiliza por esta gente trabalhando? Durante uma obra deste tipo você vai chutando as cobras pelo chão";

Joanópolis: A finalidade da reunião foi de negociar com a empreiteira a redução do preço cobrado por esta. Apesar de muita negociação, a empreiteira deu apenas um desconto de $2 \%$, mesmo depois de se tentar negociar com o representante da empreiteira a redução do preço do material cobrado por eles, pois, comparando a planilha do orçamento da empreiteira com a tabela de 
preços elaborada pela COMTEC, verificou-se que havia uma grande diferença nos preços, sendo que em alguns casos o valor cobrado era de $200 \%$ a mais que o da tabela da COMTEC;

Itapeva: Segundo o proprietário (da empreiteira), o mutirão não funciona e a redução de custos é mínima, podendo ser realizado somente para a tarefa de cavas em rochas para aterramento. Diz que a comunidade não tem capacitação técnica para outros trabalhos. Não acredita também na possibilidade da compra de materiais por parte da comunidade devido ao seu baixo poder de compra;

Miracatu: em conversa informal com representantes das empreiteiras foi constatado que elas não esperam receber os $15 \%$ dos interessados, aumentando seus custos para que os $80 \%$ a serem financiados pelo BNDES equivalessem ao custo total da obra. (...) Outro comentário dos representantes da empreiteira é a descrença de que o mutirão possa equivaler aos $15 \%$.

Na realidade, não há, na ITU-01 ou em qualquer outro documento oficial, instruções claras sobre os procedimentos relativos à utilização do trabalho da comunidade. No Rio Grande do Sul, existe uma instrução de serviço, anexa à NTD-025, que disciplina esse ponto.

Algumas vezes os interessados, quando possuem recursos suficientes, não estão muito preocupados com a redução de custos. Para eles, a alternativa proposta agora é muito mais vantajosa que o padrão anterior praticado pela concessionária, com custos significativamente maiores. Isto tem viabilizado várias obras na CPFL e na Eletropaulo. Na Eletropaulo, a maioria das ligações realizadas em 1997 era de pessoas que pagaram à vista ou de baixa renda. Na CPFL alguns interessados pedem o sistema trifásico, por já possuírem equipamentos, e negociam a diferença diretamente com a empreiteira.

A CPFL também limitou, por conta da proporcionalidade, o valor financiado em R\$ 1.200,00, mesmo que o interessado pudesse financiar mais. A alegação é de que isso somente era feito com quem pudesse pagar a diferença à vista para as empreiteiras.

Quanto aos fabricantes, a maioria tomou conhecimento do programa através de consulta, feita pelas empreiteiras ou pela Universidade de São Paulo, a seus preços. 
Alguns chegaram a participar de reuniões com comunidades, em Pindamonhangaba. Outros pediram mais informações, como o manual orientativo e uma relação de empreiteiras, que foram passadas pela Universidade. Os fabricantes de postes de madeira são os mais interessados, marcando reuniões de esclarecimento e fazendo circular no boletim interno de sua associação informações sobre o programa. Nenhum dos fabricantes contatados recusou-se a vender material diretamente às comunidades.

Não houve preocupação da CERESP em realizar reuniões ou trabalhos de divulgação formais junto às associações de fabricantes e empreiteiras, visando esclarecer e obter apoio ao programa. A única entidade a contatar os fabricantes e empreiteiras, de forma esporádica, foi a Universidade de São Paulo. É uma falha da coordenação do programa.

\subsubsection{A Secretaria de Energia}

A Secretaria de Estado de Energia tem a função de coordenar as ações do programa "Luz da Terra" através da CERESP, gerenciando-o em todos os seus aspectos, desde a aprovação de cada projeto e seu custo, até a ligação do beneficiário final e a prestação de contas das parcelas pagas à Nossa Caixa.

Era papel da CERESP atuar em campo?

O decreto estadual que institui o programa e o contrato com o BNDES estabelece que a CERESP deve, entre outras atribuições:

- coordenar as atividades relativas à implementação das redes de eletrificação rural do programa;

- divulgar o programa junto ao público-alvo; 
- cadastrar os interessados;

- constituir uma Comissão Técnica, em conjunto com a Universidade de São Paulo para:

- examinar os projetos e orçamentos;

- acompanhar e fiscalizar as obras.

Era previsto que, para realizar essas funções, a Secretaria de Energia deveria contar com pessoas que fossem a campo. Essa equipe conseguiu viabilizar-se apenas em outubro de 1997, e mesmo assim parcialmente.

Antes disso, a Secretaria de Energia havia considerado que as concessionárias seriam os “os braços da CERESP no campo”. Essa atitude levou aos resultados já relatados. Nem mesmo a coordenação entre os diversos órgãos participantes foi realizada a contento, visto o grande desencontro observado entre eles.

A COMTEC foi constituída em fevereiro de 1997 e, como atua apenas no final do processo, tem pouca possibilidade de efetuar correções. Os processos ainda vêm incompletos, com falta de documentação, com critérios técnicos discutíveis e incoerência dos orçamentos, forçando rejeições que alargam bastante o prazo de tramitação. A possibilidade de atuação em campo dessa comissão é pequena, mas foi importante em casos como Paranapanema e Mongaguá.

Efetivamente, o governo do estado conseguiu apenas uma implantação precária do programa, não obtendo os resultados esperados. 


\section{CAPÍTULO 5 - ANÁLISE}

\subsection{0 modelo, o fluxograma e a ação política}

Os programas tradicionais de eletrificação rural eram realizados pelas concessionárias, isoladamente, geralmente com recursos externos a elas, captados do governo ou de agências internacionais, sem muitos compromissos com os custos. Identificava-se a demanda, definia-se quem ia ser atendido e construíam-se as redes. O consumidor tinha a rede de graça ou a um custo bem subsidiado. É um modelo que provocou distorções e custos altos nas redes, não resolvendo o problema por completo, visto que há muita gente a ser atendida. Tal modelo entrou em crise, sumiram os recursos fáceis, tanto do governo como dos bancos internacionais.

O modelo usado no programa "Luz da Terra" é diferente. Os recursos são viabilizados por um banco de desenvolvimento, que exige retorno do seu investimento. Esse órgão conhece as distorções do modelo tradicional e propõe fazer eletrificação rural de custo baixo, usando sistemas técnicos simplificados e participação local nas obras de construção. Crê que é possível, com esse modelo, eliminar a exclusão, viabilizando o acesso aos moradores rurais mais pobres. Vê também a eletrificação rural como um possível instrumento de desenvolvimento, cujo processo envolve a participação de órgãos de extensão rural e de pesquisa.

Para esse modelo dar certo, um ingrediente é fundamental: a vontade política de fazer. O governo tem que assumir a política proposta e implementar ações que façam com que essa política seja realizada. Ações que implicam em colocar recursos, humanos e materiais, à disposição, convencer e fazer seus agentes de governo levar para frente 
sua política. Deve cobrar responsabilidades quando são devidas. São ações que mostram o interesse do governo pela eletrificação rural de baixo custo.

Essa vontade não foi suficientemente demonstrada pelo governo de São Paulo.

O fluxograma de ações sugere um programa mais complexo e lento que o tradicional. Há, simultaneamente a um projeto técnico, uma operação bancária de empréstimo, regida por normas rígidas e em que os riscos têm que estar claramente definidos. Os objetivos do custo baixo e da não-exclusão só são alcançados com vários esforços, de todos os organismos envolvidos.

O ponto central das ações é uma boa articulação local e o resultado dela: apoio à comunidade para que esta possa manejar o programa e acessar o crédito. As ações também são concatenadas. Uma tarefa não realizada ou realizada pela metade compromete o processo e implica em retrabalho e lentidão. A compreensão dos procedimentos e da filosofia do programa tem que ser grande.

O arranjo institucional tem que ser bem feito. Como se viu, a questão do risco bancário foi a origem da maioria dos problemas do programa "Luz da Terra". O governo não soube dar a devida importância a isso e não teve respostas adequadas ao problema quando ele surgiu. Uma das saídas, a reativação do FEER, poderia ter sido iniciada em março de 1997, e a essa altura já seria viável.

O programa "Luz da Terra" não conseguiu se impor no governo. O governo não impôs o programa "Luz da Terra" aos agentes do próprio governo. Não conseguiu. Não se deu a autoridade necessária. 


\subsection{Os atores e as ações de campo}

A falta de ação política em campo, e a conseqüente falta de envolvimento das localidades, provocou a mudança do eixo do programa: ele saiu de um modelo centrado nas comunidades e prefeituras para um modelo liderado pelas concessionárias. São elas que ditam o ritmo e o modo de implantação do programa "Luz da Terra" em cada região do estado.

O que ocorre, então, é que o programa choca-se com a cultura estabelecida dentro das empresas. As concessionárias relutam em passar de um modelo em que ela é ator único para outro modelo onde busca-se a colaboração de vários agentes. Como a transição desse modelo foi delegada à própria concessionária, os resultados foram os descritos: pouco envolvimento local, desinformação, lentidão exagerada nas ações. A concessionária tende a fazer tudo sozinha e não confia em seus parceiros.

As três maiores concessionárias estaduais mostraram resistências ao modelo. A CESP desde o início procurou caminhos alternativos, e montou um programa paralelo. A CPFL foi muito lenta nas suas ações. A Eletropaulo tentava implantá-lo mas seus agentes locais não davam suporte. O exemplo dessas empresas mostra a necessidade de uma equipe independente delas para realizar a ação política.

A aprovação da instrução ITU-01 foi considerada pelas concessionárias o ponto final da questão técnica. Após sua aprovação não mais se falou em melhoria dos padrões ou revisão de critérios. Como já observado, a falta de medidas cautelares fez com que alguns dos aspectos de redução de custos não fossem adotados, com cada concessionária adotando o que lhe fosse mais conveniente. 
A instrução técnica também deixou de lado um aspecto importante, que é a possibilidade de execução de parte da rede pela comunidade, em sistema de mutirão. Esse “esquecimento” significou que não havia diretrizes para as empresas seguirem, inviabilizando a prática generalizada do mutirão.

Ainda há bastante espaço para otimização técnica nos projetos e redução de custos. Basta aplicar alguns dispositivos da instrução técnica e reduzir a importância das empreiteiras no processo.

As empreiteiras assumiram um papel bem maior do que o previsto. O programa não tinha como diretriz principal a realização das obras apenas através da contratação de empreiteiras. Em princípio, isso deveria ocorrer somente naquelas comunidades que não pudessem ou quisessem fazer mutirão ou não tivessem apoio suficiente para comprar o material. As empreiteiras deveriam fornecer principalmente a mão-de-obra especializada. Foi a liderança assumida pelas concessionárias no programa que levou a uma mudança de procedimento, usando o jeito delas trabalharem.

A comunidade e a sociedade local deveriam ser chamadas a trabalhar para reduzir os custos. O objetivo do menor custo possível foi deixado de lado, mudando para um objetivo de custo próximo ao de referência. Na prática, as empreiteiras é que fazem o preço. Em alguns lugares, como na região de Itapeva e em Araçoiaba da Serra, faziam mais que isso, como relatado.

A tomada das ações pelas concessionárias não provocou reações na Secretaria de Agricultura, que aceitou um papel passivo, comportando-se como um parceiro menor, e não como um dos pilares do programa. A ação em campo poderia ser ditada por eles, como em alguns lugares se esboçou fazer. 
A Universidade tem a responsabilidade de zelar pelo cumprimento do programa. Freqüentemente apontava os problemas e possíveis soluções, mas não conseguia os interlocutores adequados. Cedeu em vários pontos, esperando que o programa se massificasse e fosse possível a retomada deles mais à frente, mas não teve sucesso, pois essa massificação não veio.

As Prefeituras Municipais e a sociedade local, salvo raras exceções, não foram chamadas a participar apropriadamente. Se tivessem sido, a pressão política seria maior e poderiam influenciar as concessionárias e o governo a tomar atitudes que resolvessem os problemas. Um exemplo foi a prefeitura de Paranapanema, que conseguiu viabilizar ligações em um contexto pior que o de outros municípios.

Não foi compreendido o papel do banco, que ficou com a imagem de atravancador do processo. Apesar disso, procurou soluções que pudessem facilitar o acesso ao crédito. A retirada de avalistas para os interessados com renda acima de $\mathrm{R} \$$ 7.500,00 anuais é um exemplo.

Um arranjo interessante, que contribui para reduzir a inadimplência e, consequentemente, o risco bancário, foi a instituição da cobrança do empréstimo na conta de luz, aliada à penalidade de ter a luz cortada em caso de não pagamento. Outros dois fatores que contribuem muito para reduzir a inadimplência, nem sempre lembrados, são o custo menor da ligação e ações de extensão rural, que reduzem o valor da parcela do empréstimo e tornam-na mais fácil de ser paga, respectivamente.

De modo geral, vê-se que o fluxograma de ações do programa não é cumprido. Há desencontros e a falta de informações é grande. Os agentes muitas vezes têm dúvidas e não possuem um serviço ou ponto de referência para esclarecimentos. 
Também a falta de controle e acompanhamento levou a situações de exclusão. Como o poder local não participa e a divulgação é muitas vezes negligenciada, não há garantia de atendimento total.

A divulgação do programa teve falhas também. Um programa desse porte, e que visa a mobilização local, precisa de estratégias claras de comunicação. Na fase de planejamento existia um grupo de trabalho especificamente para isso, e que sugeriu vários materiais para divulgação. Os principais, de responsabilidade dos municípios ou das concessionárias, seriam 15 milhões de folhetos em papel jornal e 5.000 faixas para colocação em lugares estratégicos, como saídas para a área rural. Pode parecer um número grande, mas se for dividido para 645 municípios, é um número realista. Os folhetos não foram feitos e as faixas, em número bem reduzido. Mesmo os materiais existentes são inadequados. O filme para televisão mostra o cadastramento como ação individual e não induz ao trabalho coletivo. O jingle para rádio foi pouco utilizado. Só a Eletropaulo o fornecia às prefeituras, e a Secretaria de Agricultura não o colocava em seus programas voltados para o produtor rural. Os cartazes do programa são espécime raro, e feitos num papel caro. Também eram previstas duas unidades móveis por concessionária, à disposição para o cadastramento em bairros rurais e festas regionais, em finais de semana e horários compatíveis com as atividades rurais(fins de tarde). A CESP e a Eletropaulo chegaram a adaptar viaturas, mas elas foram pouco utilizadas. Press-releases para a imprensa também foram pensados, mas nunca feitos.

A coordenação do programa (CERESP e Secretaria de Energia) não teve meios materiais e força política para impor sua vontade. Ou não exerceu a que tinha, ou não estava interessada em exercer. Foi omissa nas ações de campo. 
Percebe-se claramente que existe um vácuo entre o que foi planejado e o que foi executado. O modelo proposto pelo BNDES e pela Universidade de São Paulo não foi implantado. Há um espaço, situado dentro do município, que não foi preenchido nem física nem politicamente. É sobre o preenchimento desse espaço e as ações para levar a isso de que trata o próximo capítulo.

\subsection{Alguns avanços}

Muitos avanços e atitudes positivas dos atores participantes do programa "Luz da Terra" já foram ditos no decorrer deste trabalho. É verdade que os problemas encontrados ofuscam os avanços conseguidos, mas estes não são desprezíveis.

Em primeiro lugar, introduziu-se, por iniciativa da Universidade, a discussão do tema eletrificação rural de baixo custo, voltada para o público pobre, nas instâncias de governo. O governo foi induzido a identificar uma demanda social, a perceber que pode atender essa demanda de modo satisfatório e a estabelecer uma política pública voltada exatamente para essa população.

Mais ainda, levou-se essa discussão ao interior das empresas de energia, movimentando seus funcionários e tentando quebrar alguns paradigmas arraigados no seio dessas empresas em relação ao tema. As concessionárias foram forçadas a, pelo menos, estudar o assunto. O engajamento de alguns técnicos que acreditaram na proposta do programa é bem visível. Na CPFL, por exemplo, o processo de um bairro de Bofete levou a empresa a aceitar o MRT e a participação da comunidade.

Um programa foi instituído, por decreto, e um contrato de valor significativo foi assinado. 
Na área técnica, obteve-se uma norma, comum às três maiores concessionárias do estado, que privilegia o uso de sistemas MRT. As empresas foram forçadas a rever os custos praticados, adotando um sistema único para orçar seus projetos.

A Agricultura e a Nossa Caixa foram levadas a perceber que existe um público, carente de recursos e sem assistência, que necessita de suas ações, e que antes não era visível a essas instituições. A Nossa Caixa, de certa forma, retomou o projeto “Tem Força?”, abrindo uma linha especial de financiamento para proprietários rurais que desejem sistemas trifásicos para instalações de irrigação ou melhoria da produção.

O processo de discussão da eletrificação rural de baixo custo, sem exclusão, atingiu várias esferas de governo, mobilizando um grande número de pessoas em torno do tema. Pode-se afirmar que nunca, no estado de São Paulo, se discutiu a eletrificação de pobres rurais em um nível tão amplo e durante tanto tempo quanto foi discutido nesses três anos. 


\section{CAPÍTULO 6 - RESGATANDO A PROPOSTA INICIAL: SUGESTÕES PARA UMA EFETIVA IMPLEMENTAÇÃO DA POLÍTICA PLANEJADA}

Um dos principais problemas do programa "Luz da Terra" está na implementação em campo. A participação local e comunitária, linha mestra do modelo BNDES/USP, está sendo negligenciada. O objetivo deste capítulo é, então, propor ações para, em cada etapa do programa, redirecionar a prática analisada para os objetivos iniciais propostos, iniciando com um breve estudo sobre o modelo e a participação da comunidade.

\subsection{A comunidade no modelo BNDES/USP}

O modelo BNDES/USP, quando aplicado no Rio Grande do Sul, teve como um de seus resultados que os custos praticados são tão mais baixos quanto maior for o nível de organização da comunidade atingida. A necessidade de se buscar a organização da comunidade em torno dos objetivos da eletrificação rural é expressamente ressaltada na Revista do BNDES (RIBEIRO; SANTOS, 1994), nos textos avaliatórios de projetos do Banco Mundial (MUNASINGHE, 1987), e também é uma preocupação marcante das organizações que trabalham com projetos fotovoltaicos de eletrificação rural para países em desenvolvimento.

LAFUENTE (1995) descreve um processo de "avaliação rural participativa" através do qual a comunidade é chamada a identificar suas demandas, priorizá-las e compará-las com as disponibilidades de pagamento pelos serviços e instalações que podem satisfazer suas demandas energéticas. Foi uma pesquisa da Universidade de São Paulo envolvendo projeto e avaliação sistêmica de um programa de eletrificação baseado em aproveitamento de energia solar por sistemas fotovoltaicos para uma 
comunidade de pequenos e pobres produtores de trigo numa região de Cochabamba, na Bolívia. RIBEIRO et al. (1997) retomam o tema e mostram como fazer da comunidade uma parceira do planejador dos programas de eletrificação, para depois fazer dela participante também da gestão do sistema de suprimento fotovoltaico.

A Universidade de São Paulo tem tido especial cuidado em estudar o tema da participação comunitária nos programas de eletrificação rural. Já em 1989, em Relatório de Pesquisas referente a um projeto contratado com a SCDTE/SP, era apresentado um estudo de adaptação do "Manual de Construção de Redes de Distribuição" do Comitê de Distribuição (CODI) ao caso de construção de redes com aproveitamento do trabalho coletivo da comunidade beneficiada pelo sistema de mutirão. Agora, em 1997/1998, a equipe da Universidade de São Paulo está desenvolvendo estudos relativos à participação da comunidade no programa "Luz da Terra", em contrato com a Eletropaulo (EPUSP, 1997).

O custo mais baixo a que se refere o parágrafo inicial deste item, foi identificado por ROSA et al. (1993b) e dizia respeito a situações onde o nível de organização alcançado era tal que permitia à comunidade participar de um programa de treinamento para o trabalho em mutirão providenciado pela Prefeitura Municipal. O papel da prefeitura fica potencializado se ela própria cuida da organização da comunidade, já que o prefeito é o líder natural da municipalidade e com poucos recursos pode criar um serviço de suporte à eletrificação em seu município.

O grande incentivador do aproveitamento do trabalho comunitário na eletrificação rural brasileira foi o professor Enio Pinheiro Amaral, da Escola Técnica Federal de Pelotas, autor de uma obra de profunda repercussão. ROSA (1988) revela 
que um dos motivos para o Projeto Palmares ter tido o sucesso que teve foi a proximidade com o povo da terra gaúcha, sob orientação do professor Enio.

\subsection{A comunidade no programa "Luz da Terra"}

Em geral, a participação da comunidade no programa "Luz da Terra" tem sido pouco explorada. A Eletropaulo é a única empresa que tem preocupação com o seu envolvimento. Foi a única a adotar a prática de entregar os projetos diretamente a elas, enquanto as outras empresas o repassavam às empreiteiras. A Eletropaulo também se preocupa em realizar reuniões explicando o programa e citando a possibilidade da comunidade realizar o mutirão. A CESP adota esse procedimento em apenas algumas localidades.

Mesmo em lugares onde a comunidade estava informada, não acontecia a sua organização. Não é trivial para a comunidade rural cuidar de todo o processo. As lideranças não são totalmente estabelecidas, o contato é difícil pelas distâncias envolvidas, a dificuldade de locomoção até a cidade é grande na maioria dos casos, os recursos financeiros são escassos, o nível de educação formal é baixo, o medo do banco é sempre presente. Não é por acaso que ainda há uma grande parcela de famílias rurais no escuro. O sucesso dos programas de eletrificação rural comunitária no Rio Grande do Sul e no Paraná, com a efetiva participação da comunidade, deveu-se à existência de uma estrutura de apoio no município que orientava e organizava as comunidades rurais, principalmente para o mutirão. Essa estrutura não existiu no programa, apesar da Eletropaulo ter tentado formar Comissões Municipais de Eletrificação Rural, que não conseguiram coordenar-se e ser essa estrutura, em parte porque não estava clara essa responsabilidade. 
A Secretaria de Agricultura, as Prefeituras Municipais e a sociedade local podem suprir a falta dessa estrutura. Como a articulação local não foi feita, esses agentes não foram acionados. As concessionárias entraram nesse vácuo e tentaram ou realizar as tarefas que caberia à comunidade fazer, numa atitude paternalista, como a CESP e a CPFL, ou incentivá-las à organizar-se, sem muito resultado, como a Eletropaulo. Ficou bem claro que as empresas de distribuição não possuíam conhecimento ou interesse para realizar algo que implicava também numa ação política de governo.

\subsection{Proposição de ações de campo}

O programa "Luz da Terra” possui momentos bem definidos onde é importante a participação das comunidades e das entidades locais no processo. Além disso, é estruturado de tal maneira que a falha na realização de um dos passos compromete a perfeita realização dos passos seguintes. Por esse motivo, desde a fase de articulação local as entidades participantes devem planejar ações conjuntas e assumir atitudes que possibilitem o atendimento da demanda existente e a consecução dos objetivos do programa, fazendo-o com a perspectiva do resgate da cidadania do morador rural.

Nesse sentido, o primeiro passo é a mudança cultural das entidades participantes do programa. É necessário que cada órgão perceba que o público a ser atingido é diverso daquele com que está acostumado a trabalhar, e que o programa também é diferente. Ele pressupõe que o processo de eletrificação rural também é importante, e deve levar à melhoria das condições de vida do homem do campo não apenas pela chegada da energia elétrica, mas também pela possibilidade dele possuir poder decisório sobre ações que vão interferir em sua vida. Afinal, é o proprietário rural que vai pagar a linha em sua quase totalidade, e não seria justo a negação desse seu direito de 
participação. Por isso mesmo o modelo é mais trabalhoso, diferente do tradicional, onde se supunha uma ação paternalista do Estado e da concessionária, onde a única obrigação da comunidade rural era manifestar sua demanda e pagar por parte da linha. Os agentes de algumas empresas estão presos a práticas paternalistas, sempre o foram.

Também a participação de várias entidades, como bancos, órgãos de extensão rural e Prefeituras Municipais introduz um fato novo. É preciso uma grande capacidade de diálogo entre essas entidades, o que muitas vezes é algo extremamente difícil de se obter. Não deve ser perdido o foco, que é o atendimento de uma demanda social importante e, para isso, a tomada de uma atitude positiva das entidades locais já é um bom começo.

Os itens seguintes irão propor, com destaque para a implantação do Serviço Municipal de Eletrificação Rural, ações a serem desenvolvidas pelos agentes em cada um dos passos do fluxograma já apresentado, e que serve de base para o programa "Luz da Terra". Essas ações são todas no sentido de resgatar a proposta inicial do programa.

\subsubsection{Zé da Luz e o Serviço Municipal de Eletrificação Rural}

Uma das falhas observadas no programa "Luz da Terra" foi a falta de envolvimento das entidades municipais, como prefeituras e Casas da Agricultura. Várias são as vantagens de se conseguir esse envolvimento: há repartição de responsabilidades entre as instituições, os problemas são resolvidos dentro do município, a democratização e o acesso às informações são maiores, há maiores possibilidades de envolvimento da sociedade e da comunidade. 
O programa "Luz da Terra" previa que esse envolvimento se desse com a formação de uma Comissão Municipal de Apoio ao Programa, conforme foi descrito no item 4.1. A Eletropaulo elaborou, durante o processo de planejamento, uma proposta de criação dessa comissão, onde suas principais tarefas seriam:

- divulgar o programa e cadastrar os interessados;

- atuar junto à concessionária para o início e desenvolvimento do programa;

- orientar as comunidades na contratação de mão-de-obra e materiais, bem como no mutirão;

- favorecer a realização de eventos e/ou arrecadação de fundos para o programa;

- orientar a população para obtenção de documentos;

- facilitar a definição do traçado da rede e da cessão de uso da passagem e doação das redes.

A formação dessa comissão deveria ser fruto da ação política do governo do estado, através da CERESP, que a delegou às concessionárias.

A Universidade de São Paulo, em agosto de 1995, propôs a criação da figura do Zé da Luz. Esta figura seria um agente em cada cidade, ou cada região, para coordenar principalmente as ações de: 1) Divulgação. 2) Identificação de possíveis interessados. 3) Indução. 4) Preenchimento de ficha cadastral. 5) Fomento do mutirão. 6) Fomento do uso da energia.

O Zé da Luz seria uma pessoa capaz de "comprar" a idéia do programa, tornando-se o agente de suas várias etapas, começando com divulgação e 
esclarecimento. Não necessariamente teria de fazer parte da Comissão Municipal, podendo atuar como o elo de ligação entre a comissão e as comunidades rurais. Pode existir um Zé da Luz por bairro, por comunidade ou para o município todo.

A designação dessa figura pode ser feita de diversas formas. As sugestões dadas pela Universidade de São Paulo foram:

- instituir uma campanha de divulgação do programa "Luz da Terra” que tivesse como mote a identificação da figura (simpática, de forte apelo comunitário e de alguém que leva a missão de fomentar uma política estadual) do Zé da Luz;

- simplesmente pedir ao prefeito, ou quem procurasse levar o programa às comunidades, que indicasse seu Zé da Luz.

Como estratégia de marketing, propôs também que o próprio governador do estado poderia recomendar a todos os cidadãos da zona rural que fossem falar com o Zé da Luz. Ele, o Zé da Luz, seria o responsável por saber como o cidadão procederia para poder se ligar ao programa.

Esta proposta da Universidade não foi discutida de maneira mais profunda nem implantada totalmente nos municípios. Em alguns deles, como Mongaguá e Paranapanema, a presença de uma figura que atuou como Zé da Luz praticamente foi o que viabilizou o programa. Em outros, como em Pindamonhangaba, a pessoa designada estava envolvida com várias outras atividades, tornando-se inacessível às comunidades rurais. 
ROSA; MELLO (1997) ampliam o conceito da Comissão Municipal e propõem a instituição do Serviço Municipal de Eletrificação Rural (SMER), a partir de experiências desenvolvidas por eles no programa PROLUZ.

Segundo os autores, o SMER seria um órgão executivo, formado por funcionários da Prefeitura Municipal, Casa da Agricultura, Sindicato Rural e membros da sociedade local. Necessariamente é implantado sob a égide do setor público, não cabendo à iniciativa privada atuar na sua instituição.

A tarefa básica do SMER é de promover a articulação de todos os atores envolvidos no processo de eletrificação rural do município, sob a sua liderança. Outras tarefas podem ser agregadas, dependendo da iniciativa do município e do seu envolvimento com o programa. A responsabilidade mínima é divulgar o programa, cadastrar todos os interessados, assessorar e acompanhar a comunidade na formalização dos processos de crédito e técnico. Tarefas como coordenação de compra de materiais, organização de mutirões e ações de extensão também podem ser atribuições do SMER. O seu tamanho dependerá do número e tipo de etapas em que ele quiser se envolver, de acordo com as características de cada município.

Descrito desse modo, o SMER pouco difere da proposta da Comissão de Apoio, mas há alterações importantes, principalmente quanto à:

- filosofia: o SMER pressupõe uma inversão na prática observada. Todas as ações partiriam do município, que coordenaria o processo desde o início e acionaria as instituições envolvidas para a realização das tarefas que lhe cabem. Não mais seria a concessionária que ditaria o ritmo de implantação do programa; 
- ação política: quem implanta o SMER? Quem aciona as entidades municipais? Necessariamente tem que ser o governo estadual, através da CERESP, que não pode delegar essa tarefa às concessionárias. A prática mostrou que elas não vêem isso como beneficio, apenas como um trabalho a mais para seus agentes. A constituição de uma equipe independente com a responsabilidade de visitar os municípios, apresentar a política e implantar o programa é fundamental para que a proposta do SMER dê certo. O contato é feito diretamente com o poder municipal, que pode depois ser cobrado pelas responsabilidades eventualmente assumidas e não realizadas;

- execução: a implantação do SMER tem que ser feita de modo planejado e sistemático, por etapas. O processo envolve a apresentação do programa ao prefeito, buscando sua adesão e compromisso político. Em seguida, é necessária uma reunião com os agentes designados por ele, para um treinamento sobre os diversos aspectos do programa (técnicos, orçamentários, creditícios e filosóficos), pois há uma série de procedimentos que precisam ser realizados. Em seguida, é necessário um acompanhamento, no mínimo mensal, visando dirimir dúvidas, cobrar responsabilidades, resolver problemas locais e eventualmente capacitar o SMER para ações de administração de compra de materiais, de orientação de mutirões e de extensão rural. Para isso, a equipe de implantação do SMER deve ter autonomia para exercer sua função de implantar a política estadual traçada, a despeito da resistência das instituições.

Em dezembro de 1997 já existia a proposta do SMER, mas ela ainda não havia sido levada a campo. Em janeiro de 1998 foi iniciada sua implantação nas regiões de Jales e do Litoral Sul. A receptividade por parte das Prefeituras Municipais foi muito 
boa, com as mesmas entusiasmando-se e colocando recursos humanos à disposição. Os resultados, na forma de apresentação de projetos à CERESP, devem aparecer um pouco mais à frente, pois é necessário um tempo de maturação e aprendizado do programa em cada município, em torno de três a quatro meses. Outra questão a ser equacionada é a capacidade da CERESP em multiplicar a implantação do SMER em cada município. Da forma atual, com duas pessoas, a capacidade de acompanhamento é de no máximo 80 municípios. Uma idéia é a de formar multiplicadores de implantação. Os dois iniciais formariam dois implantadores, que formariam outros quatro, até que haja total cobertura do estado.

O SMER pode atuar em inúmeras frentes, e ser tão grande quanto a disposição do município em atender a população rural. Apenas é preciso que haja a correta indução das forças locais por um agente externo, mostrando as suas possibilidades e capitalizando a vontade do município. Os itens 6.3 .3 a 6.3.8 mostram como o SMER pode atuar em cada etapa do processo de eletrificação rural.

\subsubsection{A questão da divulgação de informações}

Um aspecto importante a ser trabalhado é a divulgação de informações sobre eletrificação rural às instituições participantes e aos produtores rurais. SANTOS (1996), na avaliação do modelo BNDES/USP, afirma que devem ser tomados cuidados especiais para se conseguir a adesão e o envolvimento dos agentes em diferentes níveis dentro dos órgãos participantes. Este foi um dos pontos observados na implantação do programa "Luz da Terra" em que houve mais falhas. Havia deficiências de informação sobre o programa em todos os níveis. 
PAZZINI et al. (1997) propõem um modelo de abordagem e divulgação de informações cujo objetivo é conseguir a participação da sociedade nas discussões sobre desenvolvimento rural sustentado e, em particular, nas decisões sobre o fornecimento de energia elétrica ao produtor rural de baixa renda, inclusive na decisão sobre a aplicação do trabalho comunitário na construção de redes.

O modelo de abordagem proposto pelos autores é simples: pretende-se informar a sociedade em geral que um dos seus segmentos não dispõe do uso da energia elétrica e que há um plano estadual que permite o resgate desse débito. A sociedade é induzida a identificar a demanda de um de seus segmentos e fustigar as instituições cobrando a ação de seus agentes (funcionários, gerentes, prefeitos, outras autoridades).

Em síntese, o processo de abordagem se desenvolve em quatro etapas com diferentes temas, alvos e objetivos, conforme a tabela 6 . 
Tabela 6

Modelo de Abordagem e Divulgação de Informações

\begin{tabular}{cccl}
\hline Fase & Tema & Alvo & \multicolumn{1}{c}{ Objetivo } \\
\hline Primeira & $\begin{array}{c}\text { Eletrificação rural } \\
\text { e resgate da cida- } \\
\text { dania }\end{array}$ & $\begin{array}{c}\text { População em } \\
\text { geral }\end{array}$ & $\begin{array}{c}\text { Provocar discussão sobre o uso de } \\
\text { energia, sobre as conseqüências da } \\
\text { falta de energia nas propriedades } \\
\text { rurais pobres, sobre o impacto que } \\
\text { o programa de eletrificação rural } \\
\text { pode ter, sobre as instituições en- } \\
\text { volvidas no programa }\end{array}$ \\
\hline Segunda & $\begin{array}{c}\text { O atendimento } \\
\text { das demandas da } \\
\text { sociedade }\end{array}$ & $\begin{array}{c}\text { Funcionários das } \\
\text { instituições } \\
\text { envolvidas e suas } \\
\text { chefias }\end{array}$ & $\begin{array}{c}\text { Despertar o interesse dos gerentes, } \\
\text { chefes e servidores das instituições }\end{array}$ \\
\hline Terceira & $\begin{array}{c}\text { Falta luz na área } \\
\text { rural de nosso } \\
\text { município? }\end{array}$ & $\begin{array}{c}\text { População do } \\
\text { município, } \\
\text { prefeito, políticos } \\
\text { regionais }\end{array}$ & $\begin{array}{c}\text { Envolver o prefeito e as instituições } \\
\text { locais }\end{array}$ \\
\hline Quarta & $\begin{array}{c}\text { Tem luz na sua } \\
\text { casa? }\end{array}$ & $\begin{array}{c}\text { Populações rurais } \\
\text { Divulgar o programa, identificar in- } \\
\text { teressados, induzir à participação, } \\
\text { organizar trabalho comunitário }\end{array}$ \\
\hline
\end{tabular}

Para facilitar o processo de divulgação de informações, são formados três grupos distintos de envolvidos:

1) agentes internos: funcionários das empresas de energia elétrica, funcionários do banco, funcionários da instituição responsável pela extensão rural;

2) agentes externos: empreiteiras e fornecedores de materiais, entidades municipais representativas da sociedade civil;

3) público-alvo do programa: as comunidades rurais.

O fluxo de informações tem que ser necessariamente em via dupla. A cada um desses públicos devem ser efetuadas ações de esclarecimento e divulgação dos pontos 
do programa, começando pelos agentes internos, passando pelos agentes externos e chegando às comunidades rurais.

A divulgação deve ser dialética: buscar que cada agente assuma a posição de cidadão que reclama do Estado; e das concessionárias de serviços públicos, que se cumpra com eqüidade o direito que o pobre rural tem pela luz em casa.

\subsubsection{Articulação local}

A articulação local é o momento onde busca-se o apoio do município ao programa. Não só a participação da Prefeitura Municipal, mas de toda a sociedade. É importante que se perceba que a responsabilidade pela falta de luz em uma residência não é apenas do governo ou das empresas de energia elétrica, mas de toda a sociedade. O contato com entidades que geralmente trabalham com o homem do campo, como igrejas, sindicatos rurais, associações e cooperativas deve ser buscado e fortalecido, visando agregar forças à participação local.

A maneira mais usual de informar as entidades municipais e articulá-las é através da realização de reuniões. Particularmente, a primeira reunião é de vital importância. É o momento em que se deve ganhar a adesão total ao programa. Para tanto, é necessária a participação dos representantes de todos os agentes internos e das entidades municipais.

A reunião deve ser conduzida pela equipe de implantação do programa. Uma pauta mínima a ser discutida nessa primeira reunião pode ser:

- apresentar o programa às entidades municipais, explicando-o em todas as suas etapas e detalhando o papel de cada instituição envolvida; 
- apresentar as vantagens políticas e sociais do programa;

- verificar a existência de serviços de extensão rural no município;

- mostrar as facilidades de financiamento oferecidas pelo programa;

- informar sobre a modo de formação e implantação do SMER. Verificar os recursos disponíveis para a atuação desse Serviço e a extensão que ele pode ter;

- verificar a possibilidade da prefeitura ou outro órgão executar os serviços necessários para a construção da rede elétrica, desde que haja interesse e a prefeitura tenha condições estruturais necessárias;

- propor a formação de um convênio entre a prefeitura e a instituição coordenadora do programa, visando facilitar o desenrolar do processo.

Nesse convênio, ambas as partes podem assumir alguns deveres. Por exemplo, a prefeitura pode facilitar ou possibilitar o acesso à zona rural. A instituição coordenadora do programa pode assumir a ligação gratuita das escolas rurais, centro comunitários e de pessoas comprovadamente sem condições de arcar com os custos das ligações. O convênio também é importante para permitir eventual alocução de recursos financeiros da prefeitura para ajudar no programa.

A implantação de uma figura que lidere o processo dentro do SMER, atuando como o Zé da Luz, facilita os trabalhos, pois será o agente que vai coordenar as ações do programa e cobrar as diversas entidades, além de servir como referência para a comunidade. 
A presença de uma equipe de implantação, ligada à coordenação geral do programa, é importante para esclarecer as dúvidas sobre o programa e apontar os modos onde pode haver colaboração das entidades para a redução de custos.

O agente repassador de recursos deve estar presente desde o começo do processo. Seu papel é esclarecer as pessoas da comunidade rural, geralmente de renda baixa e fora do mercado bancário, que é possível a elas obter o financiamento. Devem ser explicadas todas as implicações do empréstimo, bem como o trâmite necessário. A comunidade tem que confiar e perceber os limites da instituição bancária, um agente novo e, freqüentemente, assustador para ela. A posição a ser adotada é a de “facilitadora” do processo e não a de um órgão que impõe restrições.

A articulação local vai depender muito das características de cada município e do público a ser atendido. Cada caso é um caso. O importante é que se explore ao máximo as possibilidades de participação. Onde porventura a prefeitura não quiser assumir a coordenação, pode-se buscar em outros órgãos, ou até mesmo na oposição, o apoio necessário. O andamento do programa tem mostrado que experiências positivas impulsionam os municípios vizinhos. No Litoral Sul, o exemplo de Mongaguá animou os vizinhos Itanhaém e Peruíbe a se empenhar no programa.

\subsubsection{Identificação da demanda}

O SMER constituído deve propor uma ação conjunta dos órgãos envolvidos na propaganda e na divulgação do programa. O objetivo maior é identificar realmente $\underline{\text { todas }}$ as propriedades que não possuam energia elétrica. Se a articulação local não for bem feita, há risco de não se conseguir cadastrar todas as pessoas. Os dados iniciais que porventura estiverem disponíveis podem ajudar como estimativa, mas não podem ser 
vistos como definitivos. A identificação das propriedades rurais sem energia elétrica é uma ação de campo. É bom fazer uma divisão por áreas ou bairros para uma maior exatidão.

A elaboração de uma ficha cadastral é o primeiro contato do programa com o interessado. Nesse contato, os pontos básicos do programa devem ser informados, sem entrar em muitos detalhes. Especial atenção deve ser dada à existência de documentos necessários à obtenção do financiamento bancário na ficha. O SMER deve auxiliar na obtenção desses documentos.

A presença e participação da população nessa etapa já é recomendável. Ela deve ser incentivada a efetuar a divulgação do programa no estilo "boca a boca”, assim como ajudar na localização e cadastramento de propriedades remotas.

O Zé da Luz pode atuar mantendo o Serviço Municipal permanentemente informado sobre a situação das comunidades rurais no município. Através das informações do Zé da Luz, o SMER pode traçar seu plano de cadastramento e divulgação.

PAZZINI et al. (1997) apontam alguns artifícios de que o SMER pode se valer para facilitar o cadastramento:

- visitar escolas rurais e questionar os alunos se há ou não luz em suas casas;

- solicitar aos religiosos rurais auxílio para determinar as casas onde falta luz;

- discutir a finalidade social do programa; 
- fornecer condições para que o Zé da Luz percorra os bairros rurais para identificar as casas sem luz. Simultaneamente, o Zé da Luz pode procurar identificar os líderes de cada comunidade;

- divulgar folhetos, cartazes e faixas em todo o município. O texto nesse material deve ser simples, utilizando uma linguagem acessível aos moradores da zona rural, que muitas vezes possuem uma escolaridade bastante baixa (muitos são analfabetos);

- despertar o interesse das pessoas em ter acesso à eletricidade, ressaltando a melhoria na qualidade de vida e a possibilidade de utilização de equipamentos para se melhorar a produção agrícola.

\subsubsection{Adesão da comunidade e projeto de crédito}

Se a articulação local for bem feita e houver a implantação do SMER, a escolha da comunidade onde o programa irá iniciar-se no município, de preferência a mais organizada e que já tenha lideranças consolidadas, será facilitada. Se o programa for bem sucedido nessa comunidade-piloto, as outras comunidades provavelmente passarão a interessar-se pelo programa, contaminando positivamente as expectativas.

O processo de adesão inicia-se com a realização de uma reunião do SMER com a comunidade. A reunião deve começar com a explicação à comunidade dos pontos do programa, em linguagem acessível e com algum recurso visual, como cartazes descrevendo um fluxograma simplificado. Já nas explicações deve ficar patente que o andamento e a agilidade do processo de eletrificação vão depender sobretudo das ações da comunidade, assessorada pelo SMER. 
Após a explicação do programa, deve-se proceder à organização da comunidade, de uma maneira mais formal. Alguns pontos podem ser trabalhados:

- devem ser escolhidas lideranças da comunidade para servir de contato com as entidades e o SMER. Estas lideranças devem ter representatividade, dando-se preferência às já constituídas;

- é importante que o trabalho da comunidade não fique nas mãos de uma só pessoa. Pode ser proposto o seguinte: cada liderança fica responsável por um grupo de cinco pessoas (vizinhos), para tratar dos assuntos relativos à convocação para as reuniões e outros procedimentos. Essa pessoa ficaria encarregada de todas as tratativas referentes ao seu grupo, e seria devidamente assessorada pelo SMER e pelo Zé da Luz;

- a reunião deve ser conduzida de forma tal que já se identifique quais os trabalhos que a comunidade pode realizar em regime de mutirão. Para isso é necessário explicar os tipos de tarefas possíveis. Essa definição é comunicada às empreiteiras na ocasião de obtenção de orçamentos de mão-de-obra especializada;

- na reunião também deve ser encaminhada a resolução de problemas como impedimento bancário, servidão de passagem, ajustes no projeto elétrico, etc. Também deve ser providenciada a confecção do plano de crédito simplificado. As responsabilidades devem ser divididas, ficando bem claras as tarefas a serem realizadas por cada pessoa, da comunidade ou das instituições envolvidas.

O resultado final do processo de adesão da comunidade é a elaboração de um projeto de crédito, onde estará completamente definida a situação de cada beneficiário, a partir das informações do plano de crédito simplificado e da pesquisa cadastral junto aos 
serviços de proteção ao crédito: se ele vai pagar a rede com recursos próprios ou se ele vai pleitear o financiamento. No caso do programa "Luz da Terra", interessados de baixa renda têm sua parcela assumida pela concessionária. A atuação do SMER nessa fase é importantíssima, coordenando o processo, assessorando a comunidade e cobrando responsabilidades.

A equipe de implantação do programa atuaria em dois pontos: treinando o SMER para que realizasse as tarefas de cadastro e suprindo eventuais deficiências de organização dos municípios.

\subsubsection{Projeto técnico}

Durante o processo de adesão da comunidade, definidos os beneficiários, tem início a confecção do projeto elétrico das ligações a serem realizadas.

Este projeto, de reforço ou extensão de redes de distribuição, deve sempre adequar o sistema à demanda imediata do morador rural. A utilização de sistemas trifásicos, postes de concreto e transformadores de alta potência (acima de $15 \mathrm{kVA}$ ), usados tradicionalmente nas redes de distribuição urbana, não devem servir de padrão para a ligação do pequeno consumidor rural. O uso de sistemas simplificados, como o MRT, e de materiais mais baratos como postes de madeira, condutores de aço zincado e transformadores monofásicos são mais adequados para esse modelo. Para moradores mais distantes, onde a extensão de rede, mesmo com sistemas simplificados, tem o custo proibitivo, a utilização de sistemas fotovoltaicos é uma alternativa viável atualmente, e não pode ser descartada. 
Os projetos devem agregar grupos não muito pequenos, nem muito grandes. Grupos pequenos podem encarecer os projetos pela falta de escala, e em grupos muito grandes a dificuldade de comunicação e organização e a possibilidade de haver impedimentos bancários são maiores. Um número bom é de 10 a 40 interessados, a menos que se trate de bairros mais densamente povoados ou assentamentos. Agregar bairros rurais diferentes num mesmo projeto também não é recomendável.

A comunidade, na etapa de adesão, pode ser solicitada a auxiliar as equipes de topografia e projeto, opinando sobre o trajeto da rede e indicando a correta localização dos moradores, além de poder fornecer alojamento e alimentação às equipes.

Após o projeto elétrico estar pronto, as comunidades devem proceder à obtenção de orçamentos para a construção daquele projeto. Esta é uma etapa onde foi identificado um grande gargalo no programa, conforme observado no capítulo 4. As comunidades têm dificuldades na tarefa de contatar e negociar com as empreiteiras, ficando completamente dependentes do que elas apresentam.

O Serviço Municipal de Eletrificação Rural pode assumir essa tarefa, recebendo os projetos diretamente da concessionária e contactando as empreiteiras, dando um prazo para a resposta. Na data marcada, com a presença da comunidade, escolhe-se empreiteira e faz-se a negociação quanto aos valores apresentados.

Na etapa de orçamentos é que vão ser definidos os custos da obra. O desejável é que a obra seja de menor custo possível, buscando-se todas as possibilidades de redução. O menor custo implica em menor desembolso do cidadão rural na parcela de sua responsabilidade, em otimização do uso do dinheiro disponível para um número maior de interessados e, principalmente, redução da inadimplência pela redução do 
valor da parcela mensal do financiamento. O SMER pode atuar na redução de custos em duas frentes: na compra de materiais e na execução das obras.

Nos processos aprovados pelo programa "Luz da Terra" até o momento, as empreiteiras têm fornecido os materiais às comunidades. Isto implica que haja um acréscimo de cerca de $20 \%$ nos custos de materiais, pois a empreiteira adiciona uma margem de lucro e uma taxa de administração, além dos impostos envolvidos. O SMER pode atuar nesse item realizando a compra diretamente dos fabricantes e distribuidores dos materiais mais significativos como postes, transformadores, pára-raios, condutores, isoladores e chaves-fusíveis. A compra deve ser feita em nome da comunidade. A equipe de implantação pode treinar o SMER nessa tarefa, e a coordenação do programa pode montar um serviço centralizado de pesquisa de preços junto a fabricantes de equipamentos e materiais elétricos. Essas informações podem ser repassadas constantemente às comunidades e Serviços Municipais, num processo dinâmico e de fácil acesso, de modo a incentivar a concorrência.

\subsubsection{Contratação do financiamento e execução das obras}

Após ter o projeto de crédito e o projeto técnico prontos, o SMER envia o processo à concessionária, que o remete para a aprovação. Um serviço de informações na coordenação do programa é útil para que o SMER possa cobrar agilidade e saber em que etapa está a análise. Quando os contratos de financiamento são emitidos e precisam ser assinados pelos beneficiários, o SMER pode ajudar na comunicação e localização dos mesmos, facilitando o trabalho do banco. Após a liberação do financiamento, tem início a construção das redes. 
Uma das alternativas mais interessantes para a diminuição de custos nas instalações de eletrificação rural é a utilização do trabalho comunitário em regime de mutirão nas tarefas onde não se exige trabalho técnico especializado, como fornecimento de alimentação e alojamento, limpeza da faixa de passagem da linha de distribuição, transporte dos materiais, instalação do poste de madeira (abertura de buracos, levantamento e socagem) e instalação dos condutores (transporte, içamento e tracionamento).

A utilização de trabalho voluntário por si só já diminui grandemente o preço da obra, sendo que, na experiência realizada pela ESCELSA, em Baixo Guandu (ES), dentro do "Projeto Mutirão Comunitário", em que houve a utilização de padrões convencionais e o único item de custo reduzido foi o uso desta alternativa, a economia na execução das obras foi, segundo ABAURRE; RAMALDES (1991), de 28,3 \%.

Experiência já consagrada na construção de moradias urbanas e grandemente utilizada de forma informal nas atividades rurais, a construção em regime de mutirão traz no seu bojo inúmeras outras vantagens, além do simples barateamento dos custos:

- o trabalho em grupo, e ainda por cima voluntário, atua como um grande fator de fortalecimento dos laços de amizade e é revitalizador da vivência comunitária, como se pode observar nos seguintes depoimentos colhidos por TENDRIH (1990):

" foi feito tudo em mutirão, o pessoal, todo mundo concordou, trabalhamos alegre para que viesse a energia elétrica";

"depois que acabou, até achei falta.(...) prova que o que se faz sozinho, pouca coisa dá certo" (TENDRIH, 1990, p. 122-123); 
- a capacitação e formação de novas lideranças, quando da organização do trabalho, facilita a realização de novos empreendimentos, como irrigação, organização de cooperativas e escolas;

- o senso de comunidade, a importância do sentimento de tomar parte de um projeto que beneficia a si e à comunidade, a participação nas decisões, não podem ser desprezados dentro de um processo de contínua negação da cidadania de que o pequeno agricultor é vítima, contribuindo para sua conscientização como cidadão e diminuindo a influência de paternalismos nas relações sociais.

O efetivo sucesso de um programa de utilização de mão-de-obra voluntária só se dá com a participação da comunidade em todos os níveis de decisão, tanto no planejamento e projeto das linhas (pelo conhecimento geográfico da região), como na organização de grupos de trabalho para a construção das mesmas, devidamente orientados por técnicos eletricistas e sob a responsabilidade de um engenheiro. Sem isso, a falta de lideranças pode comprometer os cuidados com a segurança e organização do trabalho.

O SMER pode ter uma atuação importante no processo. Ele pode mostrar à comunidade que é viável realizar o mutirão e organizá-la para isso. Assim, seriam contratados apenas os serviços que exigem mão-de-obra especializada, como tracionamento, regulagem, transferência e amarração dos condutores, montagem de estruturas, instalação de postos de transformação e medição e a conexão à rede existente. Esses serviços podem ser contratados de empreiteiras ou serem fornecidos pelos próprios Serviços Municipais, se houver uma demanda de ligações considerável. Estes contratariam pessoal ou utilizariam os recursos humanos (engenheiros e 
eletricistas) porventura existentes na Prefeitura Municipal. A equipe de implantação do programa treinaria e capacitaria os Serviços Municipais para a realização dessas tarefas.

A construção das redes em mutirão é a ponta final de um trabalho que envolve a participação da comunidade em todo o processo. Sem essa participação, há o risco de que a comunidade seja utilizada apenas como mão-de-obra barata, sem que o mutirão realmente interfira como fator de organização da comunidade. É importante que isso seja evitado, para que o processo de eletrificação rural seja mais que a simples ligação de luz.

\subsubsection{Ações posteriores}

O processo de eletrificação rural não termina com a construção e ligação das redes. Há uma dívida a ser cobrada que não tem um valor desprezível para o pequeno proprietário rural. O trabalho de apoio ao produtor e a orientação quanto ao uso da energia elétrica para o aumento da produção podem propiciar um desenvolvimento econômico da propriedade eletrificada. Essa é uma tarefa que depende grandemente do extensionista, que pode aproveitar o processo de eletrificação e de organização da comunidade para introduzir novas técnicas de plantio, criação e pesca. Se a comunidade tiver efetiva participação, a elevação de sua auto-estima pode até facilitar a organização de cooperativas de produtores, se houver condições como financiamento e assistência técnica. Podem ser elaborados planos de curto e médio prazo para essas ações, a partir da chegada da eletricidade. A energia elétrica pode servir sim como vetor de desenvolvimento econômico, e o modelo proposto favorece e dá as condições para isso. 


\section{CAPÍTULO 7 - CONSIDERAÇÕES FINAIS}

\subsection{0 que mais fazer para ampliar o alcance da política?}

As dificuldades surgidas no programa "Luz da Terra" levaram os atores a sugerir algumas ações para ampliar as ações do programa.

Uma das sugestões é a criação de um fundo de aval específico para o programa. Este fundo, constituído com recursos do estado ou com uma pequena porcentagem do valor financiado a cada interessado, serviria para cobrir o risco bancário de todas as pessoas participantes, eliminando a exigência de avalistas ou de fundos que só atendam a produtores rurais, como o FEAP. Uma outra proposta, que está sendo estudada pelo BNDES, é que ele assuma esse risco bancário, pois a inadimplência verificada é bastante baixa.

Outra sugestão, em aplicação na Paraíba, é a de incluir a instalação elétrica interna da casa no financiamento. Muitas vezes as famílias não possuem recursos para essa instalação, deixando a rede ociosa por algum tempo. A CESP possui estudos mostrando que por um custo de R\$ 300,00 é possível fornecer um kit de instalação, com equipamentos que utilizam racionalmente a energia. As vantagens de fornecimento e financiamento desse kit são:

- facilidade na venda do programa de eletrificação rural;

- consumo imediato de energia, elevando o faturamento da concessionária;

- instalação adequada à boa técnica, evitando "gambiarras”, que provocam grande queda de tensão, ineficiência de equipamentos e riscos à segurança. O mesmo 
eletricista que faz a instalação da rede externa pode fazer a instalação do kit interno, sem cobrar muito mais por isso, pois já está no local;

- evita o desembolso imediato de uma parcela grande de recursos pelo beneficiário.

Uma expansão dessa proposta é o financiamento opcional de "kitseletrodomésticos”, com aparelhos para casa e "kits-produção”, com equipamentos agrícolas adequados ao uso em cada tipo de cultura. São propostas que precisam ser melhor detalhadas, e a sua viabilidade depende do arranjo financeiro, pois não se pode elevar muito a parcela a ser paga, sob o risco de comprometimento da capacidade de pagamento e conseqüente inadimplência.

A Universidade de São Paulo apresentou também um projeto, denominado “Luz de Qualidade”, para articular instituições públicas e privadas viabilizando o apoio financeiro do BNDES na criação de pequenas empresas formadas por profissionais da área elétrica em disponibilidade no mercado, como aposentados e demitidos nos processos de restruturação por que passam as concessionárias estatais, antes e depois da privatização. Estas empresas seriam constituídas já tendo um mercado potencial, no caso as obras do programa "Luz da Terra", e visariam o trabalho de reconversão produtiva de pequenas propriedades, com ações de readequação de instalações internas rurais, redimensionamento de equipamentos utilizados na produção, introdução de novas tecnologias de manejo de culturas, e outras atividades que possam agregar valor à produção utilizando a energia elétrica. A Universidade de São Paulo daria apoio tecnológico a essas empresas, que contariam com o suporte dos órgãos governamentais para a formação e capitalização inicial. 
Tal projeto, apresentado à coordenação do programa "Luz da Terra", despertou pouco interesse das instituições envolvidas. Apenas a Secretaria de Agricultura solicitou maiores informações e se dispôs a trabalhar no projeto.

As investigações realizadas e a análise da prática do programa "Luz da Terra" e, principalmente, enriquecidas com as opiniões de Fábio Rosa e Ricardo Mello, consultores do programa, permitem que se apresentem as seguintes sugestões para o aprimoramento das ações de campo, além das já apresentadas: cobrança da taxa de cadastro da Nossa Caixa na primeira conta de luz; definição clara de quem está excluído pelo governo do estado de São Paulo do serviço de luz elétrica; obrigar que as concessionárias atendam ao compromisso de ligar o baixa renda; reformular a sistemática de orçamentação e contratação do financiamento (o agente financiaria a obra no valor de referência, e somente após a liberação do crédito ela seria contratada); capacitar e treinar projetistas para a utilização de sistemas simplificados e unificação das fichas de cadastramento, visando facilitar o seu preenchimento.

Todas essas sugestões, inclusive a proposta do SMER, precisam ainda encontrar um maior eco dentro do governo paulista que, como visto, não tem demonstrado vontade para implantar a política que ele próprio formulou.

\subsection{0 modelo é bom?}

Cabem aqui algumas considerações sobre o modelo utilizado no programa "Luz da Terra". A primeira questão é: ele é bom? A resposta é sim, se for bem aplicado. É preciso o engajamento efetivo dos órgãos e da vontade do governo em fazer, como em qualquer outro modelo. Uma avaliação foi feita pelas próprias concessionárias, em outubro de 1997. Nessa ocasião, o Diretor de Distribuição da CPFL relatou que teve 
dificuldades em entender o modelo, mas quando o entendeu e o aplicou, viu que dava certo. A Universidade de São Paulo então propôs à CESP realizar uma experiência aplicando o modelo, coisa que ela não aceitou. Existia um pré-julgamento de que era ruim e não interessava à empresa.

No programa "Luz da Terra", verificou-se que as falhas foram muito mais pelo boicote dos atores do que por ser um modelo excessivamente complicado. Ele pode e deve ser replicado, onde existirem condições políticas favoráveis. Apenas deve-se estar atento às duas questões básicas já mostradas neste trabalho, quais sejam: o cuidado com o risco bancário e com a capacidade operacional de campo. Ganha-se muito se as decisões e as ações forem concentradas nos municípios. O poder local e os beneficiários podem encontrar suas próprias soluções de atendimento.

Outra consideração é que ele permite que alternativas de geração descentralizadas e renováveis, como energia solar, eólica, biomassa, micro-usinas hidrelétricas, etc. possam ser utilizadas. Apenas não se pode descartar a extensão de rede como uma alternativa plenamente viável, com simplificações técnicas que a tornam de custo acessível ao público-alvo do modelo, os pequenos produtores e moradores mais pobres da zona rural. É falso afirmar, como se faz ultimamente, que a alternativa de extensão de rede faliu porque as concessionárias não se interessam mais em utilizá-la. O PROLUZ e o "Luz da Terra" mostram outros caminhos.

Uma questão em aberto é em relação ao comportamento do modelo num mercado competitivo e privatizado, cenário muito próximo atualmente. O modelo proposto exige uma grande participação do governo. Como as empresas privadas reagirão a uma proposta como a do "Luz da Terra"? Que modificações terão que ser feitas em relação a tarifas e subsídios para que a eletrificação rural seja atraente? Como 
exigir das empresas mudanças de padrões técnicos para viabilizar o atendimento de consumidores de baixa demanda e esparsos?

Algumas pistas já existem hoje. Algumas concessionárias, já privatizadas, vêem na eletrificação rural oportunidades de expandir seu mercado, ocupar espaços e melhorar a imagem da empresa. O financiamento direto ao beneficiário é um atrativo, pois não mobiliza recursos próprios da companhia nem aumenta seu passivo (o que aconteceria se elas fossem financiadas diretamente, o que é possível). Essas companhias, como a CPFL fez, poderiam assumir o risco das operações, que têm um histórico de baixa inadimplência.

Tais questões sugerem novos estudos e ações por parte dos órgãos reguladores e financiadores. A Universidade de São Paulo, com a experiência adquirida na avaliação e assessoria de programas de eletrificação rural de baixo custo, tem muito a colaborar nesse sentido.

\subsection{Conclusão do texto}

A eletrificação rural em São Paulo, no período estudado (1995-1997), confirmou ser uma matéria que ultrapassa os aspectos técnicos. As razões de seu fracasso, ou dos desencontros havidos, têm suas raízes no caráter político das decisões.

Foi proposto um novo modelo de fazer eletrificação rural. Não deveria haver exclusão e o acesso de todos os habitantes da área rural à eletricidade deveria ser perseguido incessantemente. Os projetos teriam que ser adequados à demanda, usando preferencialmente sistemas de distribuição simplificados. Buscava-se a sustentabilidade econômica. O beneficiário teria condições de pagar sua obra de eletrificação, mediante 
um arranjo de crédito adequado ao seu perfil de renda. A política proposta previa a participação dos poderes locais, da comunidade e de outros atores que não a concessionária. A energia elétrica viria junto com mecanismos de desenvolvimento e busca da cidadania, numa perspectiva ampla. O objetivo era atender aos interesses do morador rural e da sociedade, ao menor custo e sem se contrapor aos interesses econômicos das concessionárias.

O governo de São Paulo tomou a decisão política de adotar esse modelo. Os recursos financeiros, ao contrário do habitual, eram mais do que suficientes para os objetivos propostos.

Cabia ao governo, tomada a decisão política, implementá-la.

A principal atitude seria equacionar a questão do risco bancário. Sucessivamente o governo passou essa tarefa a algumas de suas instituições, à Nossa Caixa, ao FEAP, às concessionárias. Em todas elas houve resistências, explícitas ou veladas, que o governo não conseguiu vencer. O arranjo final obtido ainda não é o ideal.

As ações de implantação em campo foram passadas às concessionárias, instituições que possuem grandes dificuldades na prática da eletrificação rural, restringindo-a a uma visão estritamente técnica. A política proposta rompia com o tradicional modo de se fazer eletrificação rural, contratando grandes empreiteiras.

A conjuntura política influenciou muito o processo. Mudanças no governo fizeram com que os objetivos ficassem menos claros e não houvesse ação para implementá-los. A parceria e a colaboração das várias esferas de governo foi rompida. A participação local foi negligenciada. As comunidades, deixadas sem apoio ou tratadas 
de modo paternalista. A influência das concessionárias e empreiteiras cresceu na medida em que o governo se omitiu.

A CERESP, comissão encarregada de impor o desejo governamental, não adquiriu a forca política necessária. Os representantes das Secretarias de Estado envolvidas eram só formais, sem poder de falar ou atuar em nome delas. Aliás, os quatro representantes e o próprio coordenador, em diferentes oportunidades, afirmaram não ter sequer acesso aos respectivos Secretários.

A não-presença do Secretário de Energia, seu presidente, junto à CERESP acabou configurando um vazio político na condução da eletrificação rural em São Paulo. A CERESP não passou de um grupo de discussão na Avenida Paulista, sem que nenhum dos seus membros pudesse ter influencia no processo. Pior, a existência formal da CERESP escondeu o vazio político.

Esse vazio político foi preenchido pelas concessionárias a um ponto tal que o coordenador do programa não se julgou com alternativa outra senão fazer o que representava a negação do modelo: entregar o programa às concessionárias.

Nesse momento, exigiu-se que a concessionária, endogenicamente, refutasse sua prática e adotasse outras, muito pouco adequadas a instituições de visão essencialmente empresarial. Uma mudança cultural imensa, que não se conseguiu realizar. Reafirmouse que a concessionária não é o ator mais indicado para liderar a implantação desse modelo.

O principal ingrediente da eletrificação rural é a vontade política. 
RIBEIRO (1993) retrata o contexto dialético onde a eletrificação rural se insere através de um diálogo na sessão de instalação da comissão criada pelo governador do Rio Grande do Sul para definir uma norma técnica para redes rurais de baixo custo. Na abertura dos trabalhos, sob a presidência do representante do BNDES, colocou o representante da Eletrobrás:

- "Estamos aqui para resolver um problema de engenharia de distribuição de energia elétrica...”

No que foi interrompido pelo representante do BNDES:

- “Não. Estamos aqui para resolver um problema de engenharia da distribuição de energia elétrica para atender a populações de baixa renda. E isto é muito diferente." 


\section{REFERÊNCIAS BIBLIOGRÁFICAS}

ABAURRE, C.; RAMALDES, A. da C. Eletrificação rural por mutirão. In. XIII Conferência Latinoamericana de Electrificacion Rural - XIII CLER. Costa Rica, abril de 1991.

BANRISUL. Programa de Eletrificação Rural Simplificada para Pequenas Propriedades Agrícolas do Estado do Rio Grande do Sul - PROLUZ. Avaliação técnica e de custos. Porto Alegre, 1993.

CEER - COMISSÃO ESPECIAL DE ELETRIFICAÇÃO RURAL - SECRETARIA ESTADUAL DE ENERGIA. Relatório final. São Paulo, junho de 1995.

CESP. Anuário estatístico de energia elétrica e gás canalizado: consumo por município: estado de São Paulo. São Paulo, 1996. (Série Indicadores, 007)

CONFERÊNCIA DAS NAÇÕES UNIDAS SOBRE MEIO-AMBIENTE E DESENVOLVIMENTO. Agenda 21. p. 471, Rio de Janeiro, 1992.

COOPERS \& LYBRAND. Projeto de reestruturação do setor elétrico brasileiro: cooperativas de eletrificação rural. Relatório VI-2. Ministério de Minas e Energia / Eletrobrás. p. 76, dezembro de 1997.

EPUSP. Laboratório de Sistemas de Potência. Processo SCTDE no 00299/89. Eletrificação Rural de Baixo Custo. São Paulo, 1989. (Relatórios Parciais e Final).

EPUSP. Departamento de Engenharia de Energia e Automação Elétricas. Contrato no D-8000-002/96. Desenvolvimento da eletrificação rural no estado de São Paulo Programa de eletrificação rural "Luz da Terra”. São Paulo, 1997. (Relatórios de Acompanhamento $n^{\text {os }} 1$ a 14 ).

FLUITMAN, F. The socio-economic impact of rural electrification in developing countries: a review of evidence. World Employment Programme Research. Geneva, novembro de 1983.

FOLEY, G. Alternative institucional approaches to rural electrification. In: Rural electrification guidebook for Asia and Pacific. Edited by G. Saunier, Bangkok, 1992

JUCÁ, A.S. Eletrificação rural de baixo custo: norma técnica e vontade política. Dissertação (mestrado). São Paulo, 1998. Escola Politécnica da Universidade de São Paulo. /no prelo/

LAFUENTE, R.J.O Eletrificação rural com sistemas fotovoltaicos. Avaliação e análise sistêmicas. Dissertação (mestrado). São Paulo, 1995. 136p. Escola Politécnica da Universidade de São Paulo.

LESSA, C. Eletrificação rural de baixo custo. Palestra proferida durante o Seminário de Utilização do CAZ. Porto Alegre, outubro de 1988. 
MUNASINGHE, M. Rural electrification for development: policy analysis and applications. Bouder, Colorado, Westview Press, 1987.

- Rural electrification in the third world. Power Engineering Journal, julho de 1990.

PEARCE, D.; WEBB, M. Rural electrification in developing countries: a reappraisal. Energy Policy, Londres. v. 15, n. 1, p.329-338, fevereiro de 1987.

PAZZINI, L.H.A.; PELEGRINI, M.A.; RIBEIRO, F.S.R. Forças vivas da sociedade participando da eletrificação rural - modelo de abordagem. In. XVI Conferência Latinoamericana de Electrificacion Rural - XVI CLER. Santiago do Chile, setembro de 1997.

RIBEIRO, F.S. Eletrificação rural de baixo custo. São Paulo, junho de 1993. 157p. Tese (Livre Docência) - Escola Politécnica, Universidade de São Paulo.

- Eletrificação rural: a inserção do engenheiro no dimensionamento de políticas sociais. In. XXIII Congresso Brasileiro de Ensino de Engenharia - COBENGE 95. Recife, outubro de 1995.

- A eletrificação rural ao alcance de todos. In. XXVI Congresso Brasileiro de Engenharia Agrícola (XXVI CONBEA). Campina Grande, julho de 1997.

RIBEIRO, F.S.; SANTOS, J.F.M. Política de eletrificação rural: superando dilemas institucionais. Revista do BNDES, n. 2, Rio de Janeiro, dezembro de 1994.

RIBEIRO, F.S.; LAFUENTE, R.J.O.; UDAETA, M.E.M. A comunidade como parceira do planejador de políticas auto-sustentadas de aproveitamento de energia solar. In. III Congresso Latinoamericano de Geração e Transmissão de Energia Elétrica - III CLAGTEE. Guaratinguetá, 1997.

ROSA, F.L.O. Projeto Palmares: uma história inédita no Brasil. Banco Nacional de Desenvolvimento Econômico e Social (BNDES). Rio de Janeiro, 1988 (mimeo)

ROSA, F. L.O.; RIBEIRO, F.S.; MELLO; R.S. Programa de eletrificação rural simplificado para pequenas propriedades agrícolas do Rio Grande do Sul/PROLUZ - Brasil: avaliação preliminar dos resultados. In: XIV Conferência Latino Americana de Electrificacion Rural (XIV CLER). Tomo VIII. Punta del Este, Uruguai, outubro de 1993 (a).

- Projeto Palmares. In: XIV Conferência Latino Americana de Electrificacion Rural (XIX CLER). Tomo VII. Punta del Este, Uruguai, outubro de 1993 (b).

ROSA; F.LO.; MELLO, R.S. Eletrificação rural simplificada. Porto Alegre, 1997. Relatório apresentado à CERESP sobre o Serviço Municipal de Eletrificação Rural.

SANTOS, J.F.M. Política de eletrificação rural. Rio de Janeiro, março de 1996. 162p. Dissertação (Mestrado) - Universidade Federal do Rio de Janeiro. 
SANTOS, J.F.M.; RIBEIRO, F.S. Gestão de um projeto auto-sustentado de eletrificação rural. In. VI Seminário Latino Americano de Gestion Tecnológica ALTEC 95. Concepcion, outubro de 1995.

TEIXEIRA, N. Eletrificação rural simplificada: sistema monofilar com retorno por terra - MRT. Rio de Janeiro, BNDES, maio, 1988. (Cadernos FINSOCIAL nº 8)

TENDRIH, L. Experiências com sistemas de eletrificação rural de baixo custo: uma análise dos impactos sócio-econômicos. Dissertação (Mestrado) Universidade Federal Rural do Rio de Janeiro. Itaguaí, Rio de Janeiro, junho de 1990. 


\section{BIBLIOGRAFIA RECOMENDADA}

ABDALLA, K. L. Energy policies for sustainable development in developin countries. Energy Policy, p. 29-36, janeiro de 1994.

BÔA NOVA, A.C. Energia e classes sociais no Brasil. Edições Loyola. São Paulo, 1985.

BOWERS, B. Social benefits of electricity. IEE Procedings, vol. 135, n 5, p. 291296, maio de 1988.

CECELSKI, E.; GLATT, S. The role of rural electrification in development. Centre for Energy Policy Research Resources for the Future. Washington DC, 1982.

CECELSKI, E. W. Enhancing socio-economic and environmental impacts of rural electrification. In: Rural Electrification Guidebook for Asia and Pacific. Edited by G. Saunier, Bangkok, 1992.

CORREIA, J.S.S. Eletrificação rural de baixo custo - avaliação e prática. São Paulo, 1992. 155p. Dissertação (Mestrado) - Escola Politécnica, Universidade de São Paulo.

CORREIA, J.S.S.; UDAETA, M.E.M. Energia elétrica e desenvolvimento rural. In: VI Congresso Brasileiro de Energia e I Seminário Latino Americano de Energia. Anais. vol. 1, p. 575 - 581, Rio de Janeiro, 1993 (a).

CORREIA; J.S.S.; UDAETA; M.E.M. O papel da energia elétrica no processo de desenvolvimento rural. In: XIV Conferência Latino-Americana de Electrificacion Rural (XIV CLER). Anais. Tomo III. Punta Del Este, 1993 (b).

DESAI, V.V. Rural electrification: review of regional experiences. In: Rural Energy Planning: Asian and Pacific Experiences. Edited by K.V. Ramani. Kuala Lampur, Asian and Pacific Development Centre, 1988.

ETFPEL - ESCOLA TÉCNICA FEDERAL DE PELOTAS. Eletrificação rural em sistema altenativo: informações gerais. p. 28, Pelotas, outubro de 1988.

FOLEY, G. Electricity for rural people. Panos Publications. Londres, 1988.

FOLEY, G. Rural electrification in the developing world. Energy Policy, v. 20, n 1, p. 145-52, Londres, fevereiro de 1992 (a).

GOLDEMBERG, J. Conservação e uso final da energia. In. Seminário Alternativas Para Uma Política Energética. Anais. p. 23-48, Campinas, 1985.

GOLDEMBERG, J. Energy, environment and development. International Academy of the Environment. Geneva, Suiça, 1995. 
JUCÁ, A.S.; RIBEIRO, F.S. Uma rede de distribuição a ser estendida. In. XVI Conferência Latinoamericana de Electrificacion Rural - XVI CLER. Santiago do Chile, setembro de 1997.

McALISTER, S. Aspectos sociales en la evaluación de proyectos de energización rural. In. XVI Conferência Latinoamericana de Electrificacion Rural - XVI CLER. Santiago do Chile, setembro de 1997.

MENKES M. A inserção de novos atores sociais no planejamento e tomada de decisão do setor elétrico. In: VI Congresso Brasileiro de Energia e I Seminário Latino Americano de Energia. Anais. vol. 1, p. 680-685, Rio de Janeiro, 1993 (a).

MUNASINGHE, M. The economics of rural electrifications projects. Energy Economics, v. 10, n. 1, p. 3-17, janeiro de 1988.

NATHAN, R.R.; NATHAN ASSOCIATES. Contribution of AID documentation to the evaluation of its rural electrifications projects. vols. I and II. 1979.

NETO, L.M.; SOTILLE, C.A. A engenharia na área rural. Revista Ensino de Engenharia, São Paulo, número 3, volume 2, p. 117-119, 2º semestre de 1984.

PAZZINI, L.H.A.; PELEGRINI, M.A.; RIBEIRO, F.S.; GALVÃO, L.C.R. Energia e desenvolvimento: modelo participativo de eletrificação rural. In. XVI Conferência Latinoamericana de Electrificacion Rural - XVI CLER. Santiago do Chile, setembro de 1997 (b).

PEREIRA, O.S. O distanciamento dos programas de eletrificação rural das políticas de desenvolvimento rural e a necessidade de uma revisão desses programas. In. I Seminário Internacional de Energia Elétrica (I SIDEE). Volume 3 - Comercialização de energia e sistemas de informação. Belo Horizonte, novembro de 1990.

RAMANI, K.V. Rural electrification and rural development. In: Rural Electrification Guidebook for Asia and Pacific. Edited by G. Saunier. Bangkok, 1992.

RANGANATHAN, V. et al. Rural electrification in Africa. Zed Books Ltda., London and New Jersey and African Energy Policy Research Network - AFREPEN. Gaborone, Botswana, 1992.

RANGANATHAN, V. Rural electrification revisite. Energy Policy, v. 1, n. 4, p.142151, fevereiro de 1994 .

RIBEIRO, F.S. O atendimento de produtores de baixa renda - um dilema institucional. In: XIV Conferência Latino-Americana de Electrificacion Rural (XIV CLER). Anais. Tomo VIII. Punta Del Este, outubro de 1993.

- A quem interessa um programa de eletrificação de propriedades rurais pobres, pouco produtivas ou mesmo improdutivas? In. XVI Conferência Latinoamericana de Electrificacion Rural - XVI CLER. Santiago do Chile, setembro de 1997. 
SAMANTA, B.B.; SUNDARAM, A.K. Socioeconomic impact of rural electrification in India. Discussion paper D-730 - Energy in Developing Countries Series, Resources for Future. Washington DC, janeiro de 1983.

SECRETARIA DO ESTADO DO INTERIOR DO PARANÁ. Eletrificação rural comunitária. 1985.

SIYAMBALAPITIYA, D.J.T. et al. Evaluation of grid connected rural electrification projects in developing countries. IEEE Transactions on Power Systems, vol. 6, n. 1, p. 332 - 337, fevereiro de 1994.

TENDLER, J. Rural electrification: linkages and justifications. Program Evaluation, Discussion Paper n 3, US AID. Washington DC, 1979.

VERA, J.G. Options for rural electrification in Mexico. IEEE Transactions on Energy Conversion, vol. 7, n 3, p. 426-432, setembro de 1992.

ZIMMERMANN, E. A. D.; GOMES, J. F. Experiência e Avaliação do Programa de Eletrificação Rural no Rio Grande do Sul - Proluz I e Perspectiva no Proluz II. Seminário Técnico do Programa “Luz da Terra”, março de 1997. 